\title{
BIULETYN SOCJOLOGII RELIGII (74)
}

ZAWARTOŚĆ: I. Sytuacje naruszające godność ludzką w ocenach i doświadczeniach młodzieży; II. Kryzys powołanych czy kryzys powołań? Zakonne powołania sióstr i braci w Polsce w latach 1900-2017.*

\section{SYTUACJE NARUSZAJACE GODNOŚĆ LUDZKĄ W OCENACH I DOŚWIADCZENIACH MŁODZIEŻY}

W sensie antropologiczno-metafizycznym godność osobowa to najważniejsza obiektywna wartość ontycznej osoby ludzkiej, to doskonałość człowieka jako bytu samoistnego. Jest następstwem bytowej struktury człowieka, ujawniającej się w rozumnym i wolnym działaniu. Tak określona godność jest wartością stałą i niezmienną, niezależną zarówno od działań (uczynków) człowieka, jak i od świadomości podmiotu. Nie ma możliwości realnego naruszenia godności, jako własności bytowej człowieka, czyli nie można zdeformować ani swojej godności, ani godności drugiego człowieka (osoba jest nienaruszalna). Jeżeli nawet człowiek żyje w sposób sprzeczny z własną godnością, czyli niegodnie, godność jako wartość nie doznaje uszczerbku w metafizycznej strukturze osoby. Godność jest wartością nienaruszalną, ale i normatywną. Uświadamiając sobie fakt posiadania tej wartości, człowiek odkrywa jednocześnie jej zobowiązujący (obligatoryjny) charakter, czyli wezwanie do życia na miarę osobowego powołania. ${ }^{1}$

Oprócz godności osobowej wymienia się jeszcze godność osobistą, osobowościową i społeczną. Człowiek przez swoje działania aktualizuje potencjalności własnej natury, kształtuje swoją godność osobowościową (dążenie do doskonałości, zwłaszcza moralnej) i godność osobistą (poczucie godności własnej i godności innych osób). Ludzie reprezentują

* Redaktorem Biuletynu socjologii religii jest prof. Eugeniusz S a k o w i c z, Warszawa.

1 K. S t ę p i én, Godność osobowa, w: K. C h a ł a s, A. M a j (red.), Encyklopedia aksjologii pedagogicznej, POLWEN Polskie Wydawnictwo Encyklopedyczne, Radom 2016, s. 377. 
różne poziomy godności, co wiąże się z jakością moralną ich osobowości. W odniesieniu do jednej i drugiej możemy mówić o różnego rodzaju deformacjach, będących zakwestionowaniem godności ludzkiej. Naruszenie godności występuje wtedy, gdy bez uzasadnionych podstaw, zwłaszcza W obecności osób trzecich, traktuje się drugiego człowieka negatywnie i wyraża się o nim w sposób poniżający. ${ }^{2}$ „Termin «naruszać godność» musi być właściwie rozumiany. Nie jest to związane z tym, że osoby te zostają w jakikolwiek sposób pozbawione godności w sensie ontologicznym - ta jest nieutracalna, ponieważ jest pochodną natury człowieka, lecz z tym, iż działania są moralnie niegodziwą odpowiedzią na tę godność. To sprawca owych niegodziwych czynów działa przeciwko swej godności osobistej, a także sam w sobie sprawia zło (skutek nieprzechodni) i przez to daje moralnie niegodziwą odpowiedź, także na swą własną godność w sensie ontologicznym. Deformacją godności jest zaniżanie poczucia własnej wartości wywołanej np. kompleksami czy negatywnym autokrytycyzmem". ${ }^{3}$

W znaczeniu społecznym godność ludzka jest odnoszona do warunków i sytuacji, w jakich człowiek żyje i działa (godność jako wartość społeczna). Jedne z tych warunków dają człowiekowi szansę optymalnego rozwoju, inne przyczyniają się do pomniejszenia jego godności, niekiedy do zniewolenia człowieka, do rezygnacji z uznawanych wartości dla innych mniej ważnych, wreszcie do totalnej demoralizacji, pozbawiającej możliwości realizacji właściwych potrzeb ludzkich. W pluralistycznym i globalizującym się świecie współczesnym rola sytuacji współczesnych w kształtowaniu postaw i zachowań godnościowych wydaje się wzrastać. W moralności godnościowej zakłada się, że utrata godności jest zła, a w niektórych przypadkach zasługuje na daleko idące potępienie. ${ }^{4}$

Mówiąc o godności jako wartości społecznej, mniej podkreślamy momenty poczuć psychicznych wierności sobie, bardziej zaś zwracamy uwagę na warunki społeczne, w których poczucie godności może być kształtowane, rozwijane lub naruszane. Pojęcie godności i jego treść operacjonalizujemy przez odniesienie do kontekstu ponadjednostkowego (społecznego). Postawy i zachowania godnościowe człowieka są tu wyznaczane nie tyle

2 A. L e k k a - K ow a li k, Godność podmiotów edukacyjnych, w: tamże, s. 385 .

3 Tamże, s. 384-385.

4 J. M a r i a ń s k i, Godność ludzka w świadomości maturzystów puławskich (1994-2009-2016), Rozprawy Społeczne 12(2018) nr 2, s. 7-15. 
przez czynniki osobowościowe, ile raczej przez uwarunkowania sytuacyjne o charakterze społecznym, wywierające bezpośredni lub pośredni wpływ. Godność człowieka przejawia się najwyraźniej w sytuacjach zagrożenia, a jej probierzem są niebezpieczeństwa i trudy. ${ }^{5}$ Do pełnego opisu godności osobowościowej i osobistej konieczne jest uwzględnienie działań ludzkich w różnych sytuacjach społecznych (godność społeczna).

W określonych warunkach człowiek godzi się na depersonalizację siebie (traktowanie osoby nie jako aktywnego podmiotu lecz poddanego manipulacji przedmiotu), nie sprzeciwia się depersonalizacji jednego człowieka przez drugiego lub grupę osób, wreszcie sam depersonalizuje inne osoby przez traktowanie ich jak rzeczy. We wszystkich tych sytuacjach dochodzi do utraty godności, kto bowiem uwłacza godności cudzej, zatraca tym samym godność własną. Godność jako wartość społeczna potwierdza się lub zaprzecza w kontaktach z innymi ludźmi i w określonych sytuacjach społecznych. Nie pojmuje się jej jako wartości bezwzględnej, niezależnej od kontekstu społecznego. Ważny jest cały klimat społeczny, w którym jest ona uznawana i realizowana, bowiem, nie ujawnia się ona i nie rozwija w próżni społecznej. ${ }^{6}$

Sytuacje negatywne uwłaczają godności, nie pozwalają żyć i rozwijać się na miarę ludzkich potencjalności. Sytuacje pozytywne zapobiegają degradacji moralnej jednostki i sprzyjają rozwojowi jej poczuć godnościowych. Kto w trudnych sytuacjach nie poddaje się okolicznościom ubliżającym jego poczuciu godności i poniżającym wprost dobre imię, kto nie godzi się na traktowanie siebie jako środka do celu, czyli w kategoriach instrumentalnych (jako rzecz, nosiciela tylko funkcji społecznych), lecz jest wyczulony na szlachetność życia i działania, ten jest wart pochwały i zachowuje swoją godność.

W rozważaniach z zakresu nauk empirycznych godność ludzką traktuje się jako godność stopniowalną, charakteryzującą w zróżnicowany sposób poszczególne jednostki, grupy społeczne i całe społeczeństwo. Jest ona opisywana zarówno od strony poczucia i świadomości własnej wartości jednostki, jak i w zastosowaniu do sytuacji życiowych, które mogą poniżać

5 A. K oj d e r, Godność i siła prawa. Szkice socjologiczno-prawne, Oficyna Naukowa, Warszawa 1995, s. 14; U. O s t r o w s k a, Studenci wobec godności. Między nieodzownościq a kontestacją, Oficyna Wydawnicza „Impuls”, Kraków 2004.

6 M. P y t k o, Elementy tożsamościowe mediów katolickich $w$ nauczaniu Jana Pawła II, w: J. S z u 1 i c h - K a ł u ż a, L. D y c z e w s k i, R. S z w e d (red.), Tożsamość i komunikacja, Wydawnictwo KUL, Lublin 2011, s. 233-244. 
godność ludzką w zdecydowany lub umiarkowany sposób, albo jej nie poniżają w ogóle według określonej zasady proporcjonalności (godność w znaczeniu społecznym jako dobro sui generis). Wskazanie na społeczne uwarunkowania godności ludzkiej nie oznacza przyjęcia rozwiązań socjologizmu, który za jedyną miarę wartości uznaje użyteczność społeczną, a pomija to, co jest poza nią - osobową godność człowieka. ${ }^{7}$

Socjologowie wskazują na różne dziedziny życia, w których mamy do czynienia z aprobatą lub dezaprobatą godności ludzkiej. Zwłaszcza w sytuacjach stwarzających stan zagrożenia człowiek może osłabiać lub wzmacniać postawy godnościowe, godząc się lub protestując przeciwko różnym formom redukcji, jakim są poddawane wartości i wymagania osoby. Społeczno-godnościowe definiowanie sytuacji zależy nie tylko od uznania uniwersalnych wartości i zasad, ale także od określonych konwencji i stereotypów kulturowych. Między sytuacjami degradującymi człowieka istnieją powiązania, mogą się one wzajemnie potęgować. Człowiek z poczuciem godności czyni dobro i unika czynów krzywdzących.

Maria Ossowska wskazuje na kilkanaście sytuacji, będących przejawem instrumentalizacji człowieka, uważanego i traktowanego jak rzecz. Są nimi: schlebianie, czyli tzw. podlizywanie się komuś ważnemu w celu uzyskania osobistych korzyści; narzucanie się komuś, kto wyraźnie nie szuka naszego towarzystwa; okazywanie ślepego posłuszeństwa i rezygnacja z własnego rozeznania u człowieka dorosłego; oportunizm jako przypadek działania w niezgodzie ze swoimi przekonaniami: człowiek podporządkowuje się normom jakiejś grupy, które wewnętrznie dezaprobuje, ale czyni to dla własnej korzyści, awansu społecznego i „świętego spokoju”; godzenie się na to, by ktoś deprecjonował nasze świadczenia przez przeliczanie ich na pieniądze, gdy taka kalkulacja wydaje się niemożliwa; nieumiejętność opanowania jakiegoś nałogu (np. człowiek, który woli żebrać niż pracować); branie udziału w publicznych konkursach piękności; sprawy związane z nieograniczoną erotyką; człowiek czuje się upokorzony, gdy dał się oszukać, nawet wtedy gdy nie pociągnęło to za sobą jakiejś wewnętrznej straty; za ubliżenie godności człowieka poczytywało się zawsze traktowanie go jako towar, wyzyskiwanie go do prywatnych celów, traktowanie jako anonimowej siły roboczej, podejmowanie decyzji w sprawach, w których decyzja powinna

7 V. E. Fr a n k 1, Homo patiens. Logoterapia i jej kliniczne zastosowanie. Pluralizm nauk a jedność człowieka. Człowiek wolny, tłum. R. C z e r n e c k i, Z. J. J a r o s z e w s k i, Instytut Wydawniczy Pax, Warszawa 1998, s. 57-58. 
należeć do niego ze względu na jego kompetencje; zarówno dobrobyt jak i niedostatek może sprzyjać albo szkodzić godności. ${ }^{8}$

Za brak godności uznaje się rezygnację z własnych wartości, poniżanie się w celu osiągnięcia jakichś korzyści, schlebianie, ślepe posłuszeństwo, oportunizm, kłamstwo, wywyższanie się, traktowanie drugiego człowieka jako środka do celu itp. Godność osobistą czy osobowościową można utracić także pod wpływem czynników zewnętrznych jak nieludzkie warunki życia i pracy, oddziaływanie systemów totalitarnych, indoktrynację i manipulację. Analizujemy tu godność, która nie przysługuje automatycznie człowiekowi jako takiemu, czyli taką, która jednym jest przypisywana, innym zaś jest odmawiana. ${ }^{9}$

Do opisu sytuacji, w których człowiek zapiera się siebie i poniża swoją godność, posłużyliśmy się kwestionariuszem ankiety zastosowanym w badaniach poglądów etycznych młodzieży polskiej 1973 r. ${ }^{10} \mathrm{Z}$ zestawu 11 sytuacji analizujemy oddzielnie sprawy należące do sfery prywatnej i publicznej oraz dziedzinę ocen związanych z moralnością seksualną. W rozważanych sytuacjach może dochodzić - według oceny maturzystów - do poniżenia godności człowieka zachowującego się w określony sposób. Można więc będzie ustalić $\mathrm{w}$ przybliżeniu przemiany $\mathrm{w}$ wyobrażeniach ludzi na temat tego, co poniża godność i w jakim stopniu. Nie jest wykluczone, że w niektórych przypadkach oceny godnościowe wypowiadane $\mathrm{w}$ formie przymiotników „godny - niegodny” wyrażają po prostu aprobatę lub dezaprobatę moralną określonych zachowań, bez zabarwienia godnościowego. Oceny godnościowe odnoszą się zarówno do cech moralności prywatnej (której standardy regulują sferę prywatnych stosunków międzyludzkich), jak i moralności publicznej (której standardy są adresowane do ludzi działających w rolach społecznych). ${ }^{11}$

W niniejszym artykule analizujemy godność ludzką z socjologicznego punktu widzenia. Kwestie te zostaną omówione w świetle badań

8 M. O s s ow s k a, Normy moralne. Próba systematyzacji, Państwowe Wydawnictwo Naukowe, Warszawa 1970, s. 54-55.

9 Tamże, s. 53-54.

10 K. K i c ińs k i, J. K u r c z e w s k i, Poglady etyczne młodego pokolenia Polaków, Wydawnictwa Radia i Telewizji, Warszawa 1977.

${ }^{11}$ K. K i c i ń s k i, Moralność prywatna a moralność publiczna, w: A. K oj d e r (red.), Jedna Polska? Dawne i nowe zróżnicowania społeczne, Wydawnictwo WAM-Komitet Socjologii PAN, Kraków 2007, s. 134-135. 
socjologicznych zrealizowanych w Puławach wśród maturzystów z liceów ogólnokształcących i techników, w latach 1994-2009-2016. Ankietę audytoryjną przeprowadzono $\mathrm{w}$ czterech tych samych szkołach ponadgimnazjalnych w Puławach i w tych samych klasach (w I Liceum Ogólnokształcącym im. księcia Adama Czartoryskiego, w Społecznym Liceum Ogólnokształcącym im. Christiana Piotra Aignera, w Technikum nr 1 i w Technikum nr 2). Do dalszych analiz statystyczno-korelacyjnych w 2016 r. włączono 286 ankiet, co stanowiło 83,6\% założonej próby badawczej. Narzędziem badawczym był kwestionariusz ankiety, zatytułowany Maturzyści a wartości moralne, opracowany w 1993 r. w Katedrze Socjologii Moralności KUL. W całej zbiorowości maturzystów w 2016 r. 82,2\% ankietowanych deklarowało swoją przynależność do katolicyzmu; 5,9\% określiło siebie jako głęboko wierzących, 55,9\% - jako wierzących, 16,8\% - jako niezdecydowanych, ale przywiązanych do tradycji religijnych, 10,8\% - jako obojętnych religijnie, $9,4 \%$ - jako niewierzących i $1,2 \%$ - to nieudzielający odpowiedzi. ${ }^{12}$

\section{Sytuacje zagrażające godności ludzkiej w życiu prywatnym}

Liczba i charakter sytuacji, w których kształtują się przekonania człowieka o jego autentycznej wartości i wartości innych ludzi, jest w rzeczywistości nieskończona, a źródła powstawania i zagrożenia poczucia godności - wielorakie. Ze względu na przyjętą, za Marią Ossowską, perspektywę teoretyczno-badawczą skupimy się na analizie wybranych sytuacji, które mogą poniżać godność ludzką lub jej nie poniżają, rozpatrywanych od strony ocen i poglądów formułowanych przez respondentów. To, co dla jednych będzie oznaką poniżenia człowieka, dla innych będzie sprawą obojętną lub neutralną z moralnego punktu widzenia. Można założyć, że im bardziej zagrożone jest poczucie godności człowieka, tym bardziej powinno wzrastać pragnienie dowartościowania własnej osoby. ${ }^{13}$

12 J. M a r i a ń s k i, Religijność maturzystów puławskich $w$ procesie przemian, Zeszyty Naukowe KUL 60(2017) nr 2, s. 225-252; O. Š t e fa ñ a k, Atmosfera ogólna i religijna w rodzinach młodzieży słowackiej, w: T. S a k o w i c z, K. G ą s i o r (red.), Sprawiedliwość i miłość w rodzinie i spoleczeństwie, t. I, Uniwersytet Jana Kochanowskiego w Kielcach, Kielce 2015, s. 88-98.

13 I. W r oń s k a, J. M a r i a ń s k i, Wartości życiowe młodzieży (na przykładzie szkót pielęgniarskich), Akademia Medyczna i Neurocentrum, Lublin 1999, s. 254-267. 
W celu zilustrowania sytuacji naruszających godność w życiu prywatnym zostały wybrane za Marią Ossowską trzy sytuacje. ${ }^{14}$ Respondentom zostały one przedstawione $\mathrm{w}$ formie trzech twierdzeń, według propozycji ocen: nie poniża, poniża, ale nie zawsze, zdecydowanie poniża i trudno powiedzieć. Młodzież z klas maturalnych jest wyczulona na rozmaite przejawy poniżania godności ludzkiej, a normy broniące godności w sferze prywatnej wywołują różne reakcje w zależności od sytuacji, do których odnoszą się te normy. Pierwsza sytuacja dotycząca życia prywatnego odnosi się do oportunizmu, gdy ktoś postępuje zgodnie z normami jakiejś grupy, przy wewnętrznej ich dezaprobacie, albo robi coś, co się opłaca, ale co się samemu w duchu potępia.

Robienie czegoś, co się opłaca, ale co się samemu w duchu potępia, uznało w 2016 r. za działanie nie poniżające godności (poza sferą godności) 5,9\% badanych maturzystów puławskich; 37,4\% - poniżające, ale nie zawsze; $38,8 \%$ - za decydowanie poniżające; $16,8 \%$ - trudno powiedzieć; $1,0 \%$ - brak odpowiedzi; w 2009 r. (odpowiednio) - 9,6\%, 40,4\%, 41,2\%, $7,2 \%, 1,6 \%$; w 1994 r. $-4,5 \%, 40,1 \%, 39,3 \%, 14,9 \%, 1,2 \%$. W latach $1994-$ -2016 nie nastąpiły wyraźniejsze zmiany w postawach badanych maturzystów w analizowanej sprawie. Łącząc odpowiedzi „poniża, ale nie zawsze” i ,zdecydowanie poniża”, wskaźniki potępienia oportunizmu kształtowały się następująco: w 1994 r. - 79,4\%, w 2009 r. - 81,6\%, w 2016 r. - 76,2\%. ${ }^{15}$

O obniżeniu się godności człowieka mówimy w sytuacji zaniku powściągliwości u ludzi nieumiejących powstrzymać się od łakomstwa, drobnych kłamstw czy nadmiernego wynoszenia własnej osoby. Druga sytuacja: „uleganie własnym słabościom, które się w gruncie rzeczy potępia (np. niepohamowane łakomstwo, pijaństwo)”, była w 2016 r. oceniana następująco: „,nie poniża” $-5,6 \%$; , poniża, ale nie zawsze" - 34,6\%; ,zdecydowanie poniża” $42,0 \%$; ,trudno powiedzieć" - 16,1\%; ,,brak odpowiedzi” -1,7\%; w 2009 r. $14,8 \%, 35,2 \%, 35,2 \%, 13,2 \%, 1,6 \%$; w 1994 r. $-14,5 \%, 33,1 \%, 35,5 \%, 15,7 \%$, 1,2\%. Łącząc dwie odpowiedzi „poniża, ale nie zawsze” i „zdecydowanie poniża", wskaźniki dezaprobaty rozważanej sytuacji kształtowały się następująco: w 1994 r. - 68,6\%, w 2009 r. - 70,4\%, w 2016 r. - 76,6\%. W latach

14 M. O s s o w s k a, O człowieku, moralności i nauce. Miscellanea, Państwowe Wydawnictwo Naukowe, Warszawa 1983, s. 514-522.

15 J. M a r i a ń s k i, Praktyki religijne a postawy godnościowe młodzieży, Studia Płockie 26/1998, s. 170-172. 
1994-2016 wzrosła dezaprobata słabości człowieka i ułomności jego natury czy niezdolności opierania się pokusom (różnica $8,0 \%$ ).

Warunki bytowe wpływają w znacznym stopniu na zachowania godnościowe w skali indywidualnej i społecznej. „W skrajnej nędzy w większości przypadków nie ma miejsca dla godności albo schodzi ona na plan dalszy. Nędza upadla narody i pojedynczych ludzi. Bezdomność, głód, brak elementarnych warunków higieny staje w rażącej sprzeczności z przynależnym człowiekowi prawem do godności. Mamy wtedy do czynienia z szybko postępującą degradacją osobowości. Ale trzeba również dodać, że dobre warunki materialne nie są wystarczające do godnych zachowań człowieka. Nierzadko bowiem dobrobyt powoduje zaślepienie i zapatrzenie w siebie. W pogoni za zyskiem człowiek zatraca cechy ludzkie. Dopuszcza się matactw gospodarczych, wyzysku, oszustw, nieuczciwości, aroganckiego i lekceważącego traktowania zatrudnionych, a nawet żywi pogardę dla tych, którym się w życiu nie udało. Pozbawiony uczuć empatii i solidarności, zatraca poczucie odpowiedzialności i godności własnej”. ${ }^{16}$

Trzeba jednak podkreślić, że nawet najgorsze warunki ekonomiczne nie są w stanie pozbawić człowieka postawy będącej wyrazem jego godności, a człowiekowi o bardzo dobrych warunkach bytowych może towarzyszyć świadomość i wola czynienia dobra, poczucie odpowiedzialności za własne czyny, gotowość niesienia pomocy innym. ${ }^{17}$ Dobrze i godnie można żyć w umiarkowanym dobrobycie, ale życie może być równie nie do zniesienia wśród dostatku, jak i wśród niedostatku. Skrajna deprywacja ekonomiczna może sprzyjać wytworzeniu się swoistej subkultury, nieufności wobec każdego i wszystkich, rezygnacji i fatalizmu, może skłaniać ku różnego rodzaju przestępstwom. Niedostatek może jednak wiązać się z takimi postawami, jak: gościnność, zrozumienie potrzeb innych ludzi i współczucie. Wysoki standard życia nie zawsze prowadzi do wartościowych postaw moralnych, a bieda nie wszędzie oddziałuje w ten sam sposób. ${ }^{18}$

Trzecią sytuację: (,życie w nędznych warunkach”) oceniano w 2016 r. następująco: „nie poniża godności” - 42,3\%; ,poniża, ale nie zawsze” - 19,2\%;

16 J. Gaj d a, Wartości w życiu i edukacji człowieka, Wydawnictwo Adam Marszałek, Toruń 2013, s. 146-147.

17 Tamże, s. 147.

18 R. K. M e r t o n, Teoria socjologiczna i struktura społeczna, tłum. E. M or a w s k a, J. W e r t e n s t e i n-Ż u ł a w s k i, Państwowe Wydawnictwo Naukowe, Warszawa 1982, s. 210. 
„Zdecydowanie poniża” - 14,7\%; „trudno powiedzieć” - 22,4\%, „,brak odpowiedzi" - 1,4\%; 2009 r. $-40,4 \%, 28,2 \%, 12,8 \%, 17,2 \%, 1,4 \%$; w 1994 r. $62,8 \%, 17,8 \%, 6,6 \%, 11,2 \%, 1,7 \%$. Łącząc odpowiedzi „poniża, ale nie zawsze" i ,zdecydowanie poniża”, otrzymujemy następujące wskaźniki dezaprobaty: w 1994 r. $-24,4 \%$, w 2009 r. $-41,0 \%$ i w 2016 r. $-33,9 \%$. W latach 1994-2016 zmieniły się nieco postawy godnościowe maturzystów puławskich w kierunku większej dezaprobaty życia w nędznych warunkach (różnica 9,5\%).

Przeciętny wskaźnik postaw maturzystów odnoszących się do naruszania godności w trzech sprawach prywatnych przedstawiał się w nieco zróżnicowany sposób w trzech kolejnych badaniach socjologicznych. W $2016 \mathrm{r}$. 17,9\% badanych uważało, że w tych sytuacjach nie jest naruszana godność ludzka, 30,4\% - naruszana, ale w niewielki sposób, 31,8\% - naruszana w zdecydowany sposób, 18,4\% - trudno powiedzieć, $1,4 \%$ - nieudzielający odpowiedzi; w 2009 r. (odpowiednio) - 21,6\%, 34,6\%, 29,7\%, 12,5\%, 1,5\%; w 1994 r. $-27,3 \%, 30,3 \%, 27,1 \%, 13,9 \%, 1,4 \%$. W latach 1994-2016 zmniejszył się wskaźnik deklarujących, że w tych trzech sytuacjach nie została naruszona godność ludzka (różnica 9,4\%) i zwiększył się wskaźnik twierdzących, że została tu naruszona godność w zdecydowany sposób (różnica 4,7\%). W latach 1994-2016 nieco wrosło wyczulenie młodzieży maturalnej na sytuacje naruszania godności w sprawach prywatnych (osobistych). ${ }^{19}$

Poczucie godności w sprawach prywatnych różnicowało się ze względu na cechy demograficzne, społeczne i religijne. W 2016 r. kobiety - według wskaźnika zbiorczego - deklarowały w 15,5\%, że w trzech analizowanych sprawach z życia prywatnego nie dochodzi do naruszania godności, w $30,1 \%$ - że dochodzi do tego, ale nie zawsze, 33,4\% - że zdecydowanie poniża, 19,4\% - trudno powiedzieć, w 1,6\% - brak odpowiedzi; mężczyźni (odpowiednio) - 21,6\%, 30,8\%, 29,7\%, 16,9\%,1,1\%. Kobiety wykazywały nieco wyższe wyczulenie na naruszanie godności ludzkiej w sytuacjach prywatnych niż mężczyźni, ale różnice mieściły się w przedziale kilku punktów procentowych. Jest interesujące, czy ta tendencja potwierdzi się

19 J. Mł y ń s k i, W kręgu aksjologii abiturientów Tarnowa. Wartości osobowe, społeczne i religijno-moralne w świadomości młodzieży, Wydawnictwo Diecezji Tarnowskiej Biblios, Tarnów 2008, s. 184. 
w odniesieniu do spraw należących do spraw do sfery publicznej lub leżących na pograniczu sfery prywatnej i publicznej. ${ }^{20}$

Młodzież uczęszczająca do szkół ogólnokształcących deklarowała w $18,3 \%$, że w tych trzech analizowanych sytuacjach odnoszących się do sfery prywatnej nie ma naruszenia godności ludzkiej, w 30,7\% - jest naruszenie, ale nie zawsze, w $32,4 \%$ - jest naruszenie w zdecydowany sposób, w 17,9\% - trudno powiedzieć i w 0,7\% - brak odpowiedzi; młodzież ucząca się w technikach (odpowiednio) - 17,6\%, 30,2\%, 31,3\%, 18,9\%, 2,0\%; młodzież mieszkająca na wsi lub w miastach do 20 tys. mieszkańców (odpowiednio) - 17,7\%, 31,4\%, 30,9\%, 17,9\% 2,1\%, w miastach powyżej 20 tys. mieszkańców, głównie w Puławach - 18,3\%, 28,7\%, 33,3\%, 19,3\%, $0,3 \%$. Ani typ szkoły, ani miejsce zamieszkania nie różnicowało poglądów maturzystów puławskich w omawianej kwestii naruszania godności ludzkiej wybranych sytuacjach życia prywatnego.

Autodeklaracje religijne i autodeklaracje praktyk religijnych różnicowały poglądy maturzystów w odniesieniu do poczucia godnościowego w sprawach prywatnych. Wierzący uważali w $17,5 \%$, że w trzech analizowanych sprawach - według wskaźnika zbiorczego - nie jest naruszana godność, w 30,7\% - jest naruszana, ale nie zawsze, w 33,7\% - jest naruszana w zdecydowany sposób, w 16,9\% - trudno powiedzieć i w 1,3\% brak odpowiedzi; niezdecydowani, ale przywiązani do tradycji religijnych (odpowiednio) - 19,5\%, 29,9\%, 35,4\%, 15,3\%, 0,0\%; obojętni religijnie $8,6 \%, 35,5 \%, 21,5 \%, 31,2 \%, 3,2 \%$; niewierzący - 30,8\%, 27,1\%, 28,4\%, $13,6 \%, 0,0 \%$; praktykujący w każdą niedzielę (odpowiednio) - 16,7\%, $27,1 \%, 35,2 \%, 20,0 \%, 0,9 \%$, dwa lub trzy razy w miesiącu $-18,2 \%, 31,5 \%$, $34,6 \%, 15,7 \%, 0,0 \%$, raz w miesiącu lub kilka razy w roku $-16,5 \%, 33,3 \%$, $32,7 \%, 14,3 \%, 3,2 \%$, w ogóle niepraktykujący $-22,8 \%, 29,0 \%, 22,9 \%$, $25,3 \%, 0,0 \%$.

W miarę przechodzenia od wierzących do niewierzących zmniejsza się nieco wskaźnik deklarujących naruszenie godności w zdecydowany sposób (różnica 5,3\%) i od praktykujących regularnie do w ogóle niepraktykujących (różnica 12,3\%). Religijność sprzyja wyczuleniu godnościowemu w sprawach życia prywatnego, ale różnice między osobami należącymi do różnych kategorii autoidentyfikacji religijnej i autoidentyfikacji praktyk

20 J. M a r i a ń s k i, Przemiany moralności polskich maturzystów w latach 1994-2009. Studium socjologiczne, Wydawnictwo KUL, Lublin 2011, s. 398-400. 
religijnych nie są zbyt wysokie. ${ }^{21}$ Wyższy poziom poczuć godnościowych charakteryzował bardziej kobiety niż mężczyzn, osoby wierzące bardziej niż indyferentne religijnie lub niewierzące, osoby regularnie praktykujące bardziej niż niepraktykujące. Typ szkoły i wielkość miejsca zamieszkania nie różnicowały tych postaw. W latach 1994-2016 te poczucia godnościowe nieco wzrosły wśród maturzystów puławskich.

Młodzież z klas maturalnych jest wyczulona na rozmaite przejawy poniżania godności ludzkiej, a normy broniące godności w sferze prywatnej wywołują różne reakcje w zależności od sytuacji, do których odnoszą się te normy. W $2016 \mathrm{r}$. uznano za zdecydowanie poniżającą sytuację ulegania własnym słabościom, które się w gruncie rzeczy potępia, nieco rzadziej robienie czegoś, co się opłaca, ale w gruncie rzeczy się potępia i najrzadziej dostrzegano niebezpieczeństwo utraty godności w sytuacji pozostawiania w nędznych warunkach materialnych. Położenie materialne człowieka nie zawsze zależy od niego samego, może być spowodowane przez czynniki zewnętrzne i instytucjonalne. Żyć z godnością można zarówno w trudnych warunkach materialnych, jak i w dobrobycie, oraz zarówno dobrobyt jak i niedostatek mogą pociągać za sobą obniżenie wartości człowieka jako człowieka.

\section{Sytuacje zagrażające godności w relacjach międzyludzkich}

Godność osobowa wymaga, by szanować każdego człowieka, nie naruszać jego godności i tworzyć warunki do jej akceptacji. Godność osobowościowa i osobista $z$ kolei pomaga stawiać czoło trudnym i niebezpiecznym okolicznościom, wytrwać w swoich przekonaniach i uznawanych wartościach, chroni przed nieszanowaniem osób stojących niżej w hierarchii społecznej (np. zawodowej) i przed służalczością stojących wyżej. Krótko mówiąc, pozwala kształtować postawy i zachowania oraz relacje interpersonalne oznaczające respektowanie godności ontycznej osoby ludzkiej. ${ }^{22}$

Według Marii Ossowskiej w życiu codziennym poczytuje się na ogół za brak godności schlebianie komuś w oczekiwaniu na drobne lub większe korzyści osobiste (tzw. podlizywanie się, nadskakiwanie innym), ślepe

${ }^{21}$ L. S m y c z e k, Dynamika przemian wartości moralnych $w$ świadomości młodzieży licealnej. Studium panelowe, Towarzystwo Naukowe KUL, Lublin 2002, s. 281-292.

22 A. L e k k a - K ow a li k, Godność podmiotów edukacyjnych, s. 386. 
posłuszeństwo dorosłego człowieka rezygnującego z własnego rozeznania, płaszczenie się przed innymi, służalstwo, godzenie się na to, by ktoś zapłacił za jakieś świadczenia uznane przez nas za nieprzeliczalne na pieniądze. W opinii niektórych ludzi przyjmowanie napiwków jest praktyką upokarzającą godność człowieka. ${ }^{23}$ Pochlebstwa, fałszywe komplementy, pozorowany aplauz, których celem jest uzależnienie od pochlebcy lub wymuszenie jakiegoś rewanżu od tego, któremu schlebiamy, jest przeciwieństwem szacunku jako ważnej wartości w relacjach międzyludzkich. ${ }^{24}$

W podjętej analizie na przykładzie młodzieży maturalnej chodzi o ocenę niekorzystnych z moralnego lub społecznego punktu widzenia sytuacji jako zagrażających lub niezagrażających godności ludzkiej. Z długiej listy możliwych sytuacji społecznych, w których byłaby pomniejszana lub degradowana godność ludzka, wybieramy następujące: schlebianie i przytakiwanie komuś, kto ma władzę, z myślą o własnych korzyściach; ciągłe narzucanie się komuś, o kim wiemy, że nie szuka naszego towarzystwa; przyjęcie pieniędzy jako wynagrodzenia od rodziców dziecka, któremu uratowało się życie w czasie pożaru; przyjmowanie napiwków (drobnych sum pieniędzy), np. przez fryzjera, taksówkarza, kelnera; powtarzanie zwierzchnikom, o czym rozmawiają koledzy w pracy.

Młodzież maturalna z Puław okazała się nieco bardziej wyczulona na rozmaite przejawy naruszania godności w stosunkach międzyludzkich niż w dziedzinie spraw prywatnych. Schlebianie i przytakiwanie komuś, kto ma władzę, z myślą o własnych korzyściach, zostało ocenione w 2016 r. w następujący sposób: nie poniża $-6,6 \%$; poniża, ale nie zawsze $-32,5 \%$; zdecydowanie poniża - 47,2\%; trudno powiedzieć - 12,6\%; brak odpowiedzi - 1,0\%; w 2009 r. (odpowiednio) - 9,2\%, 32,4\%, 43,6\%, 14,0\%, 0,8\%; w 1994 r. - 2,5\%, 33,5\%, 48,3\%, 13,6\%, 2,1\%. Dezaprobata pełna lub umiarkowana w sytuacji schlebiania i przytakiwania kształtowała się następująco: w 1994 r. - 81,8\%, w 2009 r. - 76,0\%, w 2016 r. - 79,7\% (stabilizacja opinii). Mniej niż co dziesiąty badany maturzysta uważał, że poniżanie siebie $w$ celu osiągnięcia osobistych korzyści nie wiąże się $\mathrm{z}$ wartościami godnościowymi. ${ }^{25}$

23 M. O s s ow s k a, O człowieku, moralności i nauce. Miscellanea, s. 516.

${ }^{24} \mathrm{P}$. S z t o m p k a, O pojęciu kultury raz jeszcze, Studia Socjologiczne 1/ 2019, s. 16-17.

${ }^{25}$ Tamże, s. 15-16. „Schlebiać znaczy: budzić przekonanie, iż człowiek jest godny większego uznania i szacunku, niż uznanie i szacunek, jakie mu ofiarują 
Druga sytuacja: ,ciągłe narzucanie się komuś, o kim wiemy, że nie szuka naszego towarzystwa”, uzyskała w 2016 r. następujące oceny: „nie poniża” $3,8 \%$; ,poniża, ale nie zawsze" - 25,5\%; ,zdecydowanie poniża” $-56,6 \%$; „trudno powiedzieć” - 12,9\%; ,brak odpowiedzi” - 1,2\%, w 2009 r. $-6,4 \%$, $24,8 \%, 56,0 \%, 12,0 \%, 0,8 \%$, w 1994 r. $-2,5 \%, 22,7 \%, 62,8 \%, 10,7 \%, 1,2 \%$. Dezaprobata pełna lub umiarkowana sytuacji ,narzucania się" kształtowała się następująco: w 1994 r. - 85,5\%, w 2009 r. - 80,8\% i w 2016 r. - 82,1\% (stabilizacja opinii). Narzucanie się komuś na siłę zostało podobnie ocenione jak i schlebianie czy przytakiwanie komuś, kto ma władzę, z myślą o własnych korzyściach.

Trzecia sytuacja: „,przyjęcie pieniędzy jako wynagrodzenie od rodziców dziecka, któremu uratowało się życie w czasie pożaru", oceniano w 2016 r. w następujący sposób: „nie poniża” - 15,4\%; ,poniża, ale nie zawsze” 22,7\%; ,zdecydowanie poniża” - 35,3\%; „trudno powiedzieć - 25,2\%; „brak odpowiedzi” - 1,4\%; w 2009 r. - 20,4\%, 24,8\%, 33,6\%, 19,2\%, 2,0\%, w 1994 r. $-16,5 \%, 22,3 \%, 33,1 \%, 26,4 \%, 1,7 \%$. Dezaprobata pełna lub umiarkowana przyjęcia wynagrodzenia za czyn altruistyczny przedstawiała się następująco: w 1994 r. - 55,4\%, w 2009 r. - 58,4\%, w 2016 r. - 58,0\% (stabilizacja opinii). Można by nawet mówić o lekkim wzroście postaw godnościowych.

Czwarta sytuacja: „przyjęcie napiwku (drobnych sum pieniędzy) np. przez fryzjera, taksówkarza, kelnera" w 2016 r. była oceniana następująco: „nie poniża” - 75,5\%; ,poniża, ale nie zawsze” - 10,1\%; „zdecydowanie poniża” - 2,8\%; „trudno powiedzieć” - 10,1\%; ,brak odpowiedzi”-1,4\%; w 2009 r. $-74,8 \%, 9,6 \%, 5,2 \%, 8,8 \%, 1,6 \%$, w 1994 r. $-67,8 \%, 11,6 \%, 5,0 \%$, $14,0 \%, 1,7 \%$. Ocena brania napiwków ma do pewnego stopnia charakter rozbieżny. Dezaprobata pełna lub umiarkowana dawania napiwków przedstawiała się następująco: w 1994 r. - 16,6\%, w 2009 r. - 14,8\%, w 2016 r. $12,9 \%$. Można by mówić o niewielkim spadku poczuć godnościowych w latach 1994-2016 w odniesieniu do przyjmowania napiwków.

jego bliscy. Pochlebstwo zmierza do przemiany aksjologicznych przeświadczeń kuszonego, związanych z dotychczasowym systemem uznań. Rozpoczyna: tamci nie mają racji - nie doceniają. Dodaje: jesteś cenniejszy, niż przypuszczasz. I wreszcie: naprawdę tylko ja cię doceniam. I tak już na samym początku pokusy ukazuje się nowa przestrzeń możliwych zawierzeń - nowe : kto-z-kim-przeciwko-komu?"; J. T i s c h n e r, Filozofia dramatu, Wydawnictwo Znak, Kraków 2006, s. 201. 
Piąta sytuacja: ,powtarzanie zwierzchnikom, o czym rozmawiają koledzy w pracy” była oceniana w 2016 r. w następujący sposób: „nie poniża” $5,2 \%$; „poniża, ale nie zawsze" $-26,6 \%$; ,zdecydowanie poniża” $-45,5 \%$; „trudno powiedzieć” - 21,3\%; „brak odpowiedzi” - 1,4\%; w 2009 r. - 10,4\%, $24,8 \%, 52,8 \%, 11,2 \%, 0,8 \%$; w 1994 r. $-1,7 \%, 14,9 \%, 71,1 \%, 11,6 \%, 0,8 \%$. Powtarzanie zwierzchnikom tego, o czym rozmawiają koledzy w pracy, uzyskało wysoki stopień dezaprobaty pełnej i umiarkowanej: w 1994 r. 86,0\%, w 2009 r. - 77,6\%; w 2016 r. - 72,1\% (spadek o 13,9\%). Być może wyników tych nie należy traktować jako zobojętnienia na problemy godnościowe, lecz raczej jako przejaw pewnej liberalizacji w ocenach moralnych. ${ }^{26}$

Przeciętny wskaźnik postaw maturzystów odnoszących się do naruszania godności ludzkiej w pięciu sprawach z zakresu relacji międzyludzkich przedstawiał się w różnicowany sposób w trzech kolejnych badaniach socjologicznych. W 2016 r. 21,3\% badanych uznawało, że w tych pięciu sytuacjach nie jest naruszana godność ludzka, w 23,5\% - naruszana ale nie zawsze, w 37,5\% - naruszana w zdecydowany sposób, w 16,4\% - trudno powiedzieć i 1,3\% - brak odpowiedzi; w 2009 r. (odpowiednio) - 24,2\%, $23,3 \%, 38,2 \%, 13,1 \%, 1,2 \%$; w 1994 r. - 18,2\%, 21,0\%, 44,1\%, $15,3 \%, 1,5 \%$.

W latach 1994-2016 wzrósł nieco wskaźnik osób deklarujących, że w tych pięciu sytuacjach nie jest naruszana godność ludzka (różnica 3,1\%) i zmniejszył się wskaźnik twierdzących, że została ta godności naruszana w zdecydowany sposób (różnica 6,6\%). W latach 1994-2016 zmniejszyło się nieco wyczulenie młodzieży na sytuacje naruszania godności w sprawach dotyczących relacji międzyludzkich. ${ }^{27}$ Wyczulenie młodzieży maturalnej na kwestie godnościowe jest większe w odniesieniu do sfery relacji międzyludzkich niż do sfery spraw prywatnych. Gdyby jednak wyłączyć ze sfery relacji międzyludzkich kwestię brania napiwków, co jest przez zdecydowaną większość badanych maturzystów sytuowane poza oceną godnościową, wówczas różnice w ocenie spraw należących do sfery prywatnej i publicznej byłyby jeszcze mniejsze.

26 J. M a ri a ń s k i, Młodzież między tradycją i ponowoczesnością. Wartości moralne w świadomości maturzystów, Redakcja Wydawnictw KUL, Lublin 1995, s. $267-273$.

27 Te n ż e, Kondycja religijna i moralna młodzieży szkót średnich w latach 1988-1998-2005-2017 (raport z ogólnopolskich badań socjologicznych), Wydawnictwo Adam Marszałek, Toruń 2018, s. 358. 
Poczucie godności w relacjach międzyludzkich różnicowało się nieco ze względu na cechy demograficzne i społeczne. W 2016 r. kobiety - według wskaźnika zbiorczego - deklarowały w 20,6\%, że w pięciu analizowanych sprawach nie dochodzi do naruszenia godności, w 22,5\% - że dochodzi, ale nie zawsze, w $38,6 \%$ - że poniża w zdecydowany sposób, w $16,8 \%$ trudno powiedzieć, w 1,6\% - brak odpowiedzi, mężczyźni (odpowiednio) -22,4\%, 24,9\%,35,9\%, 16,0\%, 0,8\%; młodzież z liceów ogólnokształcących $-22,3 \%, 24,2 \%, 37,0 \%, 16,1 \%, 0,4 \%$, młodzież z techników - 20,4\%, 22,8\%, $38,0 \%, 16,8 \%, 2,0 \%$; młodzież mieszkająca na wsi lub w miastach do 20 tys. mieszkańców - 20,9\%, 24,2\%,38,9\%, 14,0\%, 2,1\%, młodzież mieszkająca w Puławach - 22,0\%, 22,4\%, 35,2\%, 20,4\%, 0,0\%. Cechy demograficzne i społeczne tylko nieznacznie różnicowały poglądy młodzieży maturalnej w Puławach w odniesieniu do relacji międzyludzkich. Kobiety nieco częściej niż mężczyźni deklarowały naruszenie godności w analizowanych sytuacjach, młodzież z techników częściej niż z liceów ogólnokształcących, młodzież ze wsi i z miast do 20 tys. mieszkańców częściej niż mieszkająca w Puławach. Różnice między nimi wynosiły zaledwie po kilka punktów procentowych.

Autodeklaracje religijne różnicowały nieznacznie poglądy maturzystów w odniesieniu do postaw progodnościowych. Osoby wierzące w 20,7\% deklarowały, że w pięciu analizowanych sprawach dotyczących relacji międzyludzkich nie dochodzi do naruszania godności ludzkiej, w 24,1\% - że dochodzi, ale nie zawsze, w 39,1\% - że dochodzi w zdecydowany sposób, w $15,3 \%$ - trudno powiedzieć i w $0,9 \%$ - brak odpowiedzi; niewierzący (odpowiednio) - 31,8\%, 21,5\%, 34,1\%, 12,6\%, 0,0\%; praktykujący w każdą niedzielę - 21,5\%, 25,1\%,36,0\%, 16,6\%, 0,8\%, w ogóle niepraktykujący $24,8 \%, 18,5 \%, 36,7 \%, 20,0 \%, 0,0 \%$. Wierzący nieco częściej niż obojętni religijnie i niewierzący wskazywali na naruszanie godności ludzkiej w relacjach międzyludzkich. Postawy progodnościowe osób praktykujących i niepraktykujących były podobne.

Młodzież z klas maturalnych jest wyczulona na rozmaite przejawy poniżania godności ludzkiej, a normy broniące godności w relacjach międzyludzkich wywołują różne reakcje w zależności od sytuacji, do których odnoszą się te normy. Według maturzystów puławskich z 2016 r. wśród czynów zagrażających godności w relacjach międzyludzkich - według kategorii „zdecydowanie poniża” - na pierwszym miejscu znalazło się ciągłe narzucanie się komuś, o kim wiemy, że nie szuka naszego towarzystwa (56,6\%), a dalej: schlebianie i przytakiwanie komuś, kto ma władzę, z myślą 
o własnych korzyściach (47,2\%); powtarzanie zwierzchnikom, o czym rozmawiają koledzy w pracy (45,5\%); przyjęcie pieniędzy lub jakiegoś wynagrodzenia od rodziców dziecka, któremu uratowało się życie w czasie pożaru (35,3\%). Tylko nieliczni badani dopatrywali się zdecydowanego naruszenia godności w braniu napiwków i w sytuacji życia w nędznych warunkach.

Ogólne konstatacje dotyczące maturzystów puławskich na temat postaw godnościowych młodzieży potwierdzają wnioski z wcześniejszych badań ogólnopolskich. „Postawy wobec wartości godnościowych są bardzo przychylne. Wierność ważnym, własnym przekonaniom w sytuacji silnego nacisku; życie wśród tych, którzy nas akceptują, a nie - narzucanie się obcym; lojalność wobec swego kręgu koleżeńskiego; zachowanie niezależności wobec osób mogących decydować o losie człowieka - są czterema elementami określającymi człowieka godnego. Uleganie potępianym przez siebie słabościom, przyjmowanie gratyfikacji materialnej za czyn heroiczny - nie dyskwalifikuje już tak jednoznacznie godności człowieka, przeciwnie niż lizusostwo, donosicielstwo i narzucanie się innym. Na pierwszy plan wysuwają się więc czyny przeciwko grupie «swoich», naruszające swoistość i prywatność małych kręgów koleżeńskich". ${ }^{28}$

\section{Sytuacje naruszające godność ludzką w sferze życia erotycznego}

Analizę sytuacji, w których godność ludzka jest lekceważona, pomniejszana lub poniżana, można odnieść do sfery życia erotycznego. W społeczeństwie tradycyjnym normy moralności seksualnej były surowsze dla kobiet (asymetria ocen dotyczących moralności seksualnej). „Szczególnie wielkie zmiany w obrazie człowieka, którego cenimy, zaszły w obrazie kobiety. Przez długie wieki wymagano od kobiety wyłącznie czystości płciowej przed ślubem, wierności po ślubie i cnót strzegących harmonii i ciepła ogniska domowego. Dziś czystość płciowa nie stanowi już głównej ozdoby kobiety, która mając większe niż dawniej pole działania, może uwydatnić się także innymi walorami... Dziś erotyka stała się w większym stopniu sprawą prywatną - skądinąd nie błahą, gdy wchodzi w grę godność i wyrobienie estetyczne". ${ }^{29}$

${ }^{28}$ K. K i c i ń s k i, J. K u r c z e w s k i, Poglądy etyczne młodego pokolenia Polaków, s. 130.

${ }_{29}$ M. O s s o w s k a, O człowieku, moralności i nauce. Miscellanea, s. 545. 
Współcześnie zaznacza się tendencja do zrównania płci, jeśli chodzi o surowość obyczajową czy rygoryzm w sprawach seksualnych; „,seks przestał być tabu, a nawet przybrał rozmiary biznesu i przemysłu. I to nie tylko w zakresie usług heteroseksualnych. Rosną też rzesze prostytuujących się mężczyzn. Niezależnie od prostytucji rewolucja seksualna spowodowała rozluźnienie obyczajowe. Cudzołóstwo wśród dorosłych jest niemal powszechne, tak jak uprawianie stosunków seksualnych wśród młodzieży, zwłaszcza w kręgach studenckich. Z dziewczynami już się teraz nie chodzi, tylko się sypia. Podczas «imprez» pary korzystają z pokoju nazywanego na tę okazję «rozkoszniaczkiem». Seks traci niejednokrotnie charakter intymności. Pary kochają się, nie krępując obecnością innych. «Impreza» wieńczona była konkursem, kto ostatni skończy z dziewczyną. Zwycięzca, jako godny uznania, stawia flaszkę na «rozchodniaczka». Wszelkie perwersje w pożyciu intymnym są uważane za godne człowieka, jeśli są chciane przez partnerów". ${ }^{30}$

W referowanych badaniach przedstawiono młodzieży maturalnej trzy sytuacje do oceny według kategorii „godne - niegodne”: wzięcie przez kobietę udziału w publicznym konkursie piękności; częste zmienianie przez kobietę kochanków, wśród których, jak to się mówi, nie przebiera; częste zmienianie przez mężczyznę kochanek, wśród których, jak to się mówi, nie przebiera. Wyraźnie poza sferą zagrażającą godności mieści się wzięcie przez kobietę udziału w publicznym konkursie piękności. Sugestia wysunięta przez Marię Ossowską o poniżającej wymowie udziału kobiety w takim konkursie nie potwierdza się we współczesnych warunkach społeczno-kulturowych. Środki masowego przekazu przyczyniają się do popularyzacji samych konkursów, a także swoistego przewartościowania walorów ludzkiego ciała. Konkursy piękności nie są na ogół oceniane w kategoriach poszanowania lub nieposzanowania godności ludzkiej.

Wyraźnie poza sferą zagrażającą godności mieści się wzięcie przez kobietę udziału w publicznym konkursie piękności. Około dwie trzecie badanych maturzystów w $2016 \mathrm{r}$. nie dostrzegało w tego typu zachowaniach najmniejszego zagrożenia dla godności ludzkiej i ujmowało je bardziej w kategoriach estetycznych niż moralnych $(64,0 \%) ; 11,2 \%$ - dostrzegało naruszenie godności, ale nie zawsze, $3,5 \%$ - dostrzegało w zdecydowany

30 J. G a j d a, Wartości w życiu i edukacji człowieka, s. 145-146; Z. B a u m a n, Th. L e o n c in i, Płynne pokolenie, tłum. S. Ż u c h o w s k i, Wydawnictwo Czarna Owca, Warszawa 2018, s. 69-101. 
sposób, 19,9\% - trudno powiedzieć i 1,4\%- brak odpowiedzi; w 2009 r. (odpowiednio) - 64,4\%, 18,0\%, 10,0\%, 6,0\%, 1,6\%; w 1994 r. - 83,5\%, 5,0\%, $1,7 \%, 8,7 \%, 1,2 \%$. W latach 1994-2016 zmniejszył się wyraźnie wskaźnik nieuznających konkursów piękności za przejaw naruszenia godności kobiety (różnica 19,5\%) oraz zwiększył się wskaźnik tych, którzy zdecydowanie lub umiarkowanie wskazywali na poniżenie godności kobiety w konkursach piękności (od 6,7\% do 14,7\%).

Dwie dalsze kwestie dotyczą swobody erotycznej kobiet i mężczyzn. W 2016 r. w swobodzie erotycznej kobiet nie dostrzegało zagrożenia dla godności ludzkiej 5,9\% badanych maturzystów, „tak, ale nie zawsze”$12,9 \%$, „tak, w zdecydowany sposób” - 65,7\%, „trudno powiedzieć” $14,0 \%$, ,brak odpowiedzi” - 1,4\%; w 2009 r. (odpowiednio) - 11,6\%, 21,2\%, $56,8 \%, 9,6 \%, 0,8 \%$; w 1994 r. - 14,5\%, 17,8\%, 47,5\%, 18,2\%, 2,1\%. Gdybyśmy połączyli oceny „zdecydowanie poniża” i „poniża, ale nie zawsze”, wówczas wskaźniki dezaprobaty nadmiernej swobody erotycznej według kategorii godnościowych kształtowałyby się następująco: w 1994 r. - 65,3\%, w 2009 r. - 78,0\% i w 2016 r. - 78,6\% (różnica 13,3\%).

W 2016 r. 7,7\% badanych maturzystów puławskich nie dostrzegało naruszenia godności ludzkiej w nadmiernej swobodzie seksualnej mężczyzn, $17,1 \%$ - dostrzegało, ale nie zawsze, $60,1 \%$ - dostrzegało w zdecydowany sposób, 13,6\% - trudno powiedzieć i 1,4\% - brak odpowiedzi; w 2009 r. (odpowiednio) - 14,4\%, 25,6\%, 47,6\%, 10,8\%, 1,6\%; w 1994 r. - 18,6\%, $16,9 \%, 42,6 \%, 20,2 \%, 1,7 \%$. Wskaźnik ocen „zdecydowanie narusza” i ,narusza, ale nie zawsze” wynosił w 1994 r. - 59,5\%; w 2009 r. - 73,2\%; w 2016 r. - 77,2\% (różnica 17,7\%).

W latach 1994-2016 zwiększył się o 13,3\% wskaźnik tych, którzy w nieograniczonej swobodzie erotycznej kobiet dostrzegali w sposób zdecydowany lub umiarkowany poniżanie godności kobiety i o 17,7\% tych, którzy dostrzegali to samo w odniesieniu do mężczyzn. Nie potwierdziła się hipoteza wskazująca na odmienne traktowanie swobody erotycznej w odniesieniu do kobiet i mężczyzn. Znaczny rygoryzm w odniesieniu do nadmiernej swobody erotycznej kobiet i mężczyzn w kontekście ocen godnościowych nie musi oznaczać wzrostu rygoryzmu wobec kontaktów seksualnych przed małżeństwem. W 2016 r. 66,4\% badanych maturzystów uznawało za dozwolone współżycie seksualne w okresie oficjalnego narzeczeństwa, 16,4\% - to zależy, 7,3\% - za niedozwolone, 9,9\% - brak zdania lub brak odpowiedzi; w 2009 r. (odpowiednio) - 61,2\%, 19,2\%, 8,4\%, 11,2\%; w 1994 r. - 55,8\%, 
21,9\%, 14,0\%, 8,2\%. ${ }^{31}$ Dość powszechna aprobata stosunków seksualnych przed małżeństwem nie oznacza w takim samym stopniu aprobaty dla nadmiernej swobody erotycznej.

Poczucie godności w sprawach ze sfery erotycznej różnicowało się nieznacznie ze względu na cechy demograficzne i społeczne. W $2016 \mathrm{r}$. kobiety - według wskaźników zbiorczych - deklarowały w 23,8\%, że w trzech analizowanych sprawach nie dochodzi do naruszenia godności, w $11,1 \%$ - że dochodzi, ale nie zawsze, w $46,1 \%$ - że poniża $\mathrm{w}$ zdecydowany sposób, w 17,3\% - trudno powiedzieć i w 1,8\% - brak odpowiedzi; mężczyźni (odpowiednio) - 28,8\%, 17,5\%, 39,0\%, 13,9\%, 0,8\%; młodzież z liceów ogólnokształcących - 28,0\%, 13,8\%, 39,1\%, 18,4\%, 0,7\%; młodzież $z$ techników $-23,9 \%, 13,7 \%, 46,9 \%, 13,5 \%, 2,0 \%$; młodzież ze wsi i miast do 20 tys. mieszkańców - 24,1\%, 12,6\%, 46,7\%, 14,3\%, 2,3\%; młodzież z miast powyżej 20 tys. mieszkańców, głównie z Puław - 28,8\%, 15,6\%, $37,3 \%, 18,3 \%, 0,0 \%{ }^{32}$

Autodeklaracje religijne różnicują nieznacznie poglądy maturzystów w odniesieniu do postaw progodnościowych. Osoby wierzące w $2016 \mathrm{r}$. w 23,3\% deklarowały, że w trzech analizowanych sprawach dotyczących erotyki nie dochodzi do naruszenia godności ludzkiej, w 13,9\% - że dochodzi, ale nie zawsze, w 48,2\% - że dochodzi w zdecydowany sposób, w 13,5\% - trudno powiedzieć i w 1,1\% - brak odpowiedzi; niezdecydowani ale przywiązani do tradycji religijnych (odpowiednio) - 30,5\%, 9,0\%, 45,9\%, $14,6 \%, 0,0 \%$; obojętni religijnie $-24,7 \%, 18,3 \%, 29,0 \%, 24,8 \%, 3,2 \%$; niewierzący - 38,3\%, 17,3\%, 25,9\%, 18,5\%, 0,0\%; praktykujący w każdą niedzielę - 19,1\%, 14,3\%, 47,6\%, 17,6\%, 1,4\%; praktykujący dwa lub trzy razy w miesiącu - 25,2\%, 10,1\%, 52,8\%, 11,9\%, 0,0\%; praktykujący raz w miesiącu lub kilka razy w roku - 25,9\%, 13,7\%, 42,9\%, 14,6\%, 2,9\%; w ogóle niepraktykujący - 35,8\%, 16,7\%, 29,6\%, 17,9\%, 0,0\%.

Kobiety częściej niż mężczyźni deklarowały naruszanie godności ludzkiej w trzech analizowanych sprawach, młodzież z techników częściej niż z liceów ogólnokształcących, młodzież ze wsi i z miast do 20 tys. mieszkańców częściej niż młodzież z miast powyżej 20 tys. mieszkańców (głównie z Puław). Różnice między nimi wynosiły zaledwie po kilka punktów

31 J. M a ri a ń s k i, Wartości prorodzinne $w$ świadomości maturzystów puławskich (1994-2009-2006), Zeszyty Naukowe KUL 61(2018) nr 4, s. 472.

${ }_{32}$ Te n ż e, Matzeństwo i rodzina w świadomości młodzieży maturalnej-stabilność i zmiana, Wydawnictwo Adam Marszałek, Toruń 2012, s. 330. 
procentowych. Wierzący częściej niż obojętni religijnie i niewierzący wskazywali na naruszanie godności ludzkiej w sferze erotycznej, podobnie praktykujący regularnie lub prawie regularnie, częściej niż praktykujący bardzo rzadko lub w ogóle niepraktykujący.

Młodzież z klas maturalnych Puław jest dość wyczulona na rozmaite przejawy poniżania godności ludzkiej w sprawach związanych z erotyką. Zdecydowana większość badanych osób nie dopatrywała się naruszenia godności ludzkiej w konkursach piękności. W swobodzie erotycznej kobiet nieco więcej dostrzegało naruszanie godności ludzkiej niż w swobodzie erotycznej mężczyzn $(65,7 \%$ wobec $60,1 \%)$. Różnica surowo potępianych kobiet i mężczyzn w sferze swobodnej erotyki wynosiła 5,6\%. W latach 1994-2016 wskaźniki dostrzegania naruszania godności ludzkiej w swobodzie erotycznej nieco zwiększyły się. Nieco większy rygoryzm w odniesieniu do swobody erotycznej kobiet i mężczyzn nie musi oznaczać wzrostu rygoryzmu wobec kontaktów seksualnych poza małżeństwem. Według wskaźnika zbiorczego odpowiedzi „zdecydowanie poniża” największe wyczulenie na wartości godnościowe odnosi się do sfery relacji międzyludzkich, następnie do dziedziny życia erotycznego i najniższe do sfery życia prywatnego.

Przeciętny wskaźnik postaw maturzystów odnoszących się do naruszania godności w sferze życia erotycznego przedstawiał się w zróżnicowany sposób. W 2016 r. 25,9\% badanych maturzystów puławskich uznało, że w trzech sytuacjach nie jest naruszana godność ludzka, 13,7\% - jest naruszana ale nie zawsze, 43,1\% - jest naruszana w zdecydowany sposób, $15,8 \%$ - trudno powiedzieć i 1,4\% - brak odpowiedzi; w 2009 r. (odpowiednio) $-30,1 \%, 21,6 \%, 38,1 \%, 8,8 \%, 1,4 \%$; w 1994 r. $-38,9 \%, 13,2 \%, 30,6 \%$, $15,7 \%, 1,7 \%$. W latach 1994-2016 zmniejszył się wskaźnik deklarujących, że w tych trzech sytuacjach nie jest naruszana godność ludzka (13,0\%) i zwiększył się wskaźnik twierdzących, że została ta godność naruszona w zdecydowany sposób (różnica 12,5\%). W latach 1994-2016 zwiększyło się nieco wyczulenie młodzieży maturalnej na sytuacje naruszania godności w sprawach dotyczących nadmiernie swobodnego życia erotycznego. ${ }^{33}$

33 M. R o l a, Wartości moralne w świadomości maturzystów lubelskich. Studium socjologiczne, Wydawca i druk Drukarnia Standruk, Lublin 2016, s. 217-228. 


\section{Uwagi końcowe}

Przeciętny wskaźnik dla jedenastu sytuacji mogących naruszać godność ludzką dla całej badanej zbiorowości maturzystów puławskich w $2016 \mathrm{r}$. kształtował się następująco: w ogóle nie poniża $-23,0 \%$, poniża, ale nie zawsze - $19,9 \%$, zdecydowanie poniża - 39,3\%, trudno powiedzieć lub brak odpowiedzi - 17,9\%, w 2009 r. (odpowiednio) - 26,7\%, 24,6\%, 36,6\%, $12,1 \%$; w 1994 r. - 30,2\%, 18,9\%, 34,1\%, 16,8\%. Łącząc odpowiedzi „zdecydowanie poniża" i „poniża, ale nie zawsze” otrzymujemy wskaźniki postaw progodnościowych: w 2016 r. - 59,2\%, w 2009 r. $-61,2 \%$, w 1994 r. - 53,0\%. W latach 1994-2016 zaznaczył się lekki wzrost postaw progodnościowych (różnica 6,2\%). ${ }^{34}$

Wartości godnościowe i poczucie godnościowe stanowią ważną część kondycji moralnej młodego pokolenia Polaków. Według Krzysztofa Kicińskiego pojęcie godności uległo w ostatnich dekadach znacznej ewolucji, ale nie stało się treściowo puste. Same terminy „godność” czy „honor” są o wiele rzadziej używane. W dalszym ciągu często jest wygłaszana opinia, że człowieka nie można pozbawiać godności, jej utrata następuje jedynie w wyniku działań własnych jednostki. ${ }^{35}$ Badania wśród maturzystów tylko częściowo potwierdzają ten wniosek. W latach 1994-2016 nie zaznaczyły się jakieś wyraźne zmiany w postawach godnościowych młodzieży. Prawie dwie trzecie badanych - według wskaźników zbiorczych - wykazuje pewne wyczulenie na rozmaite przejawy poniżania godności ludzkiej według kryteriów „zdecydowanie poniża” i „poniża ale nie zawsze”.

Można raczej mówić o pewnej stabilizacji opinii maturzystów w wielu kwestiach związanych z moralnością godnościową, a nawet być może zmniejszyło się nieco przyzwolenie społeczne na niektóre zachowania. Przyczyną tego stanu rzeczy może być fakt, że procesy indywidualizacji i liberalizacji posunęły się znacząco do przodu i osiągnęły już wystarczająco wysoki poziom. Po przełomie 1989 r. przemiany moralne następowały bardzo szybko w warunkach rozchwiania się struktur politycznych,

34 S. H. Z a r ę b a, Dynamika świadomości religijno-moralnej w warunkach przemian ustrojowych w Polsce (1988-1998), Zakład Wydawnictw Statystycznych, Warszawa 2003, s. 177; O. Š t e f a ñ a k, Wartości moralne maturzystów stowackich na przykładzie diecezji spiskiej, Wydawnictwo Norbertinum, Lublin 2013.

35 K. K i c i ń s k i, Orientacje moralne społeczeństwa polskiego, w: J. M a r i án s k i (red.), Kondycja moralna społeczeństwa polskiego, Wydawnictwo WAM, Kraków 2002, s. 391. 
gospodarczych i społecznych. W XXI w. transformacje społeczne uległy jakby pewnemu uspokojeniu. Część młodzieży być może zauważa, że zmiany w wartościach godnościowych posunęły się za daleko, warto byłoby nie pozwolić im rozwijać się dalej w kierunku rozpadu aksjologicznego. Dlatego, być może, zmniejszyło się nieco przyzwolenie społeczne na naruszanie wartości godnościowych w pewnych sytuacjach dnia codziennego.

Potrzeba poczucia godności badanych maturzystów puławskich lokuje się dość wysoko w systemie uznawanych wartości. Wśród czynów najbardziej zagrażających godności ludzkiej na pierwszym miejscu znalazło się narzucanie się komuś, kto nie szuka naszego towarzystwa i powtarzanie zwierzchnikom tego, o czym rozmawiają koledzy w pracy. Tylko nieliczni traktowali tego rodzaju działania poza kategorią godności. Tradycyjnie ostre potępienie donosu, ukształtowane w społeczeństwie polskim w trakcie doświadczeń życiowych, jest trwałym i żywym elementem narodowej kultury moralnej. Narzucanie się innym wydaje się czymś nagannym z godnościowego punktu widzenia. Nieco niżej w opinii odpowiadających znalazły się takie sytuacje, jak: bezkrytyczne podporządkowanie się władzy, pochlebstwa i przyjęcie wynagrodzenia za czyn skrajnie altruistyczny.

W dalszym ciągu Polacy silnie kojarzą z poniżaniem godności zachowania oportunistyczne, a więc te, które są niezgodne z własnymi przekonaniami i uznawanymi wartościami. Dotyczy to zachowań wynikających z chęci zysku (pieniądze, stanowisko) lub oceniane są jako ,zaparcie się siebie". Negatywna ocena zachowań oportunistycznych dobrze harmonizuje $\mathrm{z}$ wysoką oceną autonomii jednostki w dziedzinie wyborów moralnych, łącznie $\mathrm{z}$ prawem do postępowania zgodnie $\mathrm{z}$ własnymi przekonaniami. Zgodność działań z własnymi przekonaniami i uznawanymi wartościami traktuje się jako warunek pozytywnej oceny moralnej czynu. ${ }^{36}$

Omówione rezultaty badań socjologicznych tylko częściowo potwierdzają konstatacje Krzysztofa Kicińskiego. Z długoletnich jego badań socjologicznych wynika, że w poglądach ludzi dotyczących tzw. orientacji godnościowej następują wyraźne przemiany. Utrzymuje się wprawdzie nadal zdecydowana dezaprobata donosicielstwa, określanego często jako coś „obrzydliwego” i oznaczającego brak godności, ale jednocześnie dość często oceny te są opatrywane uwagami świadczącymi o sytuacyjnym pojmowaniu moralności (donosicielstwo jest złem, ale od tej oceny mogą być wyjątki). Badania socjologiczne wskazują, że obecnie wzrosła tolerancja

\footnotetext{
36 Tamże, s. 390-391.
} 
wobec zachowań naruszających godność, które mają źródło w słabościach jednostek (słaby charakter, brak silnej woli). Tego typu zachowania wielu respondentów ma skłonność interpretować w kategoriach charakterystycznych bardziej dla psychoterapii niż oceniania moralnego. Jeżeli nawet ocenianie moralne pojawia się, to oceny są raczej łagodne, uzupełniane różnymi zastrzeżeniami i są słabo kojarzone z kategorią godności. Zanika również przekonanie, że kobieta „,niewybredna erotycznie” naraża na szwank swoją godność. Wyniki badań empirycznych nie uprawomocniają tezy, że w świadomości Polaków dokonała się jakaś rewolucyjna zmiana postaw wobec norm stojących na straży prywatności, pozwalają jednak mówić o znacznym ich rozluźnieniu i słabszym kojarzeniu nieposzanowania prywatności z nieposzanowaniem godności. ${ }^{37}$

Godność nie jest tylko cechą zdobiącą człowieka, lecz wyraża istotę człowieczeństwa, skłania do doskonalenia umiejętności i cech charakteru, wierności sobie, realizacji postawionych celów, krótko mówiąc, do ciągłego podnoszenia poziomu moralnego. Wysoka ocena szacunku do siebie i wartości drugiego człowieka zakłada, że ludzie będą zdolni wykraczać poza sprawy związane z własnym interesem i doceniać także wartości moralne. Człowiek godny, opierający swoją wartość na zobiektywizowanych kryteriach moralnych, jest zdolny przeciwdziałać różnym formom bezładu społecznego i moralnego.

Godność może i powinna stać się podstawową wartością w wychowaniu, które jest procesem rozwoju osoby. Chodzi tu przede wszystkim o ukazywanie wartości godnościowych jako służących pełnemu rozwojowi człowieka, promowanie ich wśród ludzi, zwłaszcza ludzi młodych, ale i odczytywanie kontekstów społecznych ułatwiających albo utrudniających realizację tych wartości. Wychowanie progodnościowe jest wychowaniem personalistycznym. ${ }^{38}$ Kluczową sprawą w wychowaniu jest rozwijanie poczucia godności oraz kształtowanie woli postępowania w sposób godny, tj. ludzki wobec innych osób.

W kontekście przeprowadzonych badań socjologicznych wskazujących na jeszcze znaczącą obecność wartości godnościowych w świadomości

37 Tamże, s. 388-389.

38 M. Now a k, Godność osoby ludzkiej i jej implikacje pedagogiczne, w: N. R y kowska, T. L. Kun is zewska, R. St opi kowski (red.), Wśród swoich. Ksiadz Profesor Edward Walewander, Towarzystwo Naukowe KUL, Lublin 2017, s. 306-308. 
młodzieży polskiej, można by wyrazić postulat, by nauki społeczne podejmowały w większym zakresie problematykę godności ludzkiej, by stała się ona swoistą modą w psychologii, socjologii i pedagogice, co byłoby także wkładem w przezwyciężanie kryzysu moralnego we współczesnym świecie. Drugie życzenie odnosi się do Kościoła katolickiego (i innych Kościołów chrześcijańskich oraz religii) w naszym kraju, by ustawicznie głosił prawdę o godności każdego człowieka i krytycznie osądzał - z etycznego punktu widzenia - sytuacje uwłaczające godności ludzkiej. Tych ostatnich w społeczeństwie polskim nie brakuje i nie zabraknie w przyszłości. Społeczeństwo godnościowe potrzebuje godnie postępujących ludzi, dobre społeczeństwie nie będzie istnieć bez dobrych ludzi. ${ }^{39}$

ks. Janusz Mariański, Lublin

\section{KRYZYS POWOŁANYCH CZY KRYZYS POWOŁAŃ? ZAKONNE POWOŁANIA SIÓSTR I BRACI W POLSCE W LATACH 1900-2017}

Podjęty w tym artykule problem badawczy można ująć w postaci pytania: Jak kształtowały się losy zakonnych powołań kobiecych - sióstr i męskich - braci w Polsce w latach 1900-2017 w świetle istniejących statystyk kościelnych i wyników badań socjologicznych? Odpowiadając na to pytanie, należy wziąć pod uwagę zarówno liczebność kandydatów obojga płci do życia zakonnego, przyjmowanych do wspólnot zakonnych w różnych przedziałach czasowych tego okresu, jak i na liczebność sióstr i braci, którzy w tym czasie już złożyli czasowe lub trwałe śluby zakonne. W tym celu posłużę się techniką tabel statystycznych i metodą analizy danych ukazujących dynamikę tych powołań. W analizie uwzględnię także wskaźniki tych powołań w innych krajach katolickich na świecie i w Europie, chcąc w ten sposób ukazać specyfikę ich naboru i realizacji w Polsce. Ważną kwestią będzie też sytuacja powołań zakonnych w Polsce w podokresie pontyfikatu

39 J. M a ri a ń s k i, Wartości moralne w zmieniajacym się społeczeństwie polskim, Edukacja Humanistyczna 1/2011, s. 7-23; A. P o t o c k i, Sumienie w doświadczeniu moralnym Polaków, Przegląd Tomistyczny 18/2012, s. 113-128. 
Jana Pawła II, ponieważ w tym okresie powołania te były liczniejsze niż w okresie wcześniejszym. ${ }^{40}$

Życie zakonne, w pełnym lub częściowym odosobnieniu od życia świeckiego, wybierają zarówno niektóre kobiety, jak i niektórzy mężczyźni, kierowani różnymi motywami, chociaż zasadniczym motywem powinny być względy religijne - całkowite i niepodzielne oddanie się takiej osoby służbie Bogu w strukturach Kościoła instytucjonalnego, dostrzegalne w specyficznym powołaniu zakonnym. Powołanie to jest traktowane w Kościele rzymskokatolickim (i w innych Kościołach chrześcijańskich) jako specyficzny „dar” od Boga lub „głos” Boga wzywający kobietę i mężczyznę do poświęcenia własnego życia na wyłączną służbę Bogu i ludziom przez wypełnianie trzech rad ewangelicznych: posłuszeństwa władzy kościelnej, bezżenności i ubóstwa. Dar powołania zakonnego otrzymują niektóre osoby, predestynowane do życia we wspólnotach zakonnych, zgodnie z regułami w nich obowiązującymi. Osoby zakonne doskonalą własną osobowość w wymiarze religijnym, moralnym, emocjonalnym, psychologicznym i społecznym dzięki regułom obowiązującym $\mathrm{w}$ danym zgromadzeniu zakonnym. ${ }^{41}$ Taki stan życia doskonałego w Kościele rzymskokatolickim nazywa się ,życiem konsekrowanym", które może przybierać różne formy, ściśle określone przez władze zakonne. Życie konsekrowane odznacza się następującymi cechami: trwałym stylem codzienności, zobowiązaniem do wypełniania rad ewangelicznych, starannym naśladowaniem Chrystusa, pracą dla innych ludzi, stałą modlitwą osobistą i wspólną, pokorą życiową, ascezą codzienności. Cechy te ujmują podstawowy cel życia konsekrowanego kobiet i mężczyzn,

40 J. B a n i a k, Powołania zakonne w Polsce w latach 1936-1983, Tygodnik Polski 29/1984, s. 6-7; t e n ż e, Powołania zakonne w Polsce, Myśl Społeczna 23/1985, s. 4-5; t e n ż e, Liczebność zakonów w Polsce, tamże, 34/1985, s. 4-5; t e n ż e, Powołania braci zakonnych, tamże, 35/1985, s. 4-5; t e n ż e, Istota powołania zakonnego, tamże, 38/1985, s. 4-5; t e n ż e, Dynamika powolań zakonnych, tamże, 39/1985, s. 4-5; t e n ż e, Powołania zakonne w Polsce - analiza socjologiczna, Ruch Prawniczy, Ekonomiczny i Socjologiczny 1/1986, s. 279-300.

${ }^{41}$ K. D ę b o w s k a, Życie konsekrowane - jego istota i aktualna sytuacja w Polsce, w: B. Ł o z i ń s k i (red.), Leksykon zakonów w Polsce. Informator o życiu konsekrowanym, KAI, Warszawa 1998, s. 10-15; Ch. F r a n k o w s k a, Miłość oddana Bogu-opinie dziewcząt na temat powołania do życia zakonnego, Ateneum Kapłańskie 65(1962) z. 3, s. 241-257; J.W. G o g o la (1997), Ogólne wprowadzenie do formacji zakonnej, t. 1, Kraków 1997; t e n ż e, Formacja zakonna, t. 3, Kraków 1998. 
które jest realizowane w strukturach życia zakonnego, w instytutach świeckich, w stowarzyszeniach apostolskich, w formie pustelniczej - w izolacji od świata przez ciągłą modlitwę i pokutę, w środowisku dziewic, wdów i wdowców konsekrowanych za pełną aprobatą władzy kościelnej. ${ }^{1}$

Modlitwa stanowi zasadniczą i podstawową czynność codzienną zakonnic i zakonników, zwłaszcza kontemplacyjnych. Socjolog religii postrzega modlitwę zakonnic i zakonników jako rodzaj „pracy”, której efekty i środki służą ich codziennemu utrzymaniu i funkcjonowaniu w społeczeństwie. Katolicy świeccy bardzo często proszą te zakony o modlitwę w różnych sprawach: osobistych, rodzinnych, społecznych czy religijnych i moralnych, zlecając im ją w formie posługi religijnej. ${ }^{2}$

Warto jeszcze zaznaczyć, że zakonnice i zakonnicy codziennym życiem, postawami i działaniami określają sens i cel ascezy, ściśle związanej z trybem ich codzienności, nadając jej również wymiar religijny i duchowy. Styl życia zakonnego, oparty na tych zasadach, zyskuje uznanie i szacunek u katolików świeckich. Niektórzy młodzi ludzie, postanawiają pójść ich śladami i sami wybierają życie zakonne, nierzadko w zakonach kontemplacyjnych, chcąc w ten sposób poświęcić własne życie wyłącznej służbie ludziom w Kościele i w społeczeństwie. O ciągłym, choć obecnie już w mniejszym zakresie, zainteresowaniu i wyborze życia zakonnego przez młodzież polską obojga płci informują wyniki różnych badań socjologicznych. ${ }^{3}$ Losy niekapłańskich powołań zakonnych są w podobnym stopniu

1 Te n ż e, Formacja zakonne. W relacji z innymi, t. 5, Kraków 1999; M. J e w d o k i m ow, Klasztor w perspektywie socjologicznej: w poszukiwaniu nowego ujęcia, Wydawnictwo Naukowe UKSW, Warszawa 2018, s. 15-16.

2 J. B a n i a k, Desakralizacja kultu religijnego i świąt religijnych $w$ Polsce. Studium socjologiczne, Nomos, Kraków 2007, s. 51-56; t e n ż e, Dynamika nie-kapłańskich powołań zakonnych w Polsce. Studium socjograficzne, Przegląd Religioznawczy 2/2000, s. 63-87; A. C e n c i n i, Życie konsekrowane: itinerarium formacyjne $w$ drodze do Emaus, Kraków 1996.

3 J. C y m a n, Wspólnota zakonna grupa społeczna, Studia Socjologiczne 3-4/1987, s. 343-362; W. Z d a n i e w i c z, (1965), Powołanie w świadomości powołanych. Analiza osobistych ankiet kleryków i braci zakonnych, Homo Dei 4/1965, s. 236-244; t e n ż e, Wzrost czy kryzys powołań? w: W. P i w o w a r s k i, W. Z d a $\mathrm{n}$ i e w i c z (red.), Z badań nad religijnościa polską. Studia i materiaty, Pallottinum, Warszawa-Poznań, s. 189-198; J. B a n i a k, Powołania do kapłaństwa i do życia zakonnego w Polsce w latach 1900-2010. Studium socjologiczne, Wydawnictwo Naukowe Wydziału Nauk Społecznych UAM, Poznań 2012, s. 211-240; J. B a r, 
skomplikowane i uwarunkowane wieloma różnymi czynnikami jak losy powołań kapłańskich. Niektóre spośród tych czynników sprzyjają genezie i ewolucji tych powołań, zaś inne utrudniają ich zaistnienie i realizację. ${ }^{4}$

Powołania zakonne braci i sióstr stanowią, na równi z powołaniami kapłańskimi, interesujący i ważny poznawczo problem badawczy socjologii religii. Tym właśnie powołaniom zakonnym, które zostały wzbudzone, uformowane i zrealizowane w Polsce w minionym okresie 117 lat, poświęcam ten artykuł. Podstawę do analiz dynamiki tych powołań zakonnych stanowią znane i dostępne statystyki kościelne oraz wyniki niektórych badań empirycznych. Wskaźniki powołań zakonnych w Polsce będą konfrontowane $\mathrm{z}$ ich wskaźnikami w innych krajach europejskich dla celów porównawczych. ${ }^{5}$

\section{Powolania realizowane, czyli kandydatki i kandydaci do życia zakonnego w Polsce w latach 1964-2017}

Liczba bieżąca sióstr i braci zakonnych istotnie zależy od naboru nowych kandydatek i kandydatów do życia zakonnego. O taki nabór troszczą się władze każdego zakonu i zgromadzenia zakonnego. Troska ta dotyczy całego procesu społecznej genezy powołania zakonnego i trwa do dnia złożenia ślubów wieczystych, stale odnawianych przez siostrę i brata zakonnego. Co więcej, troska ta bynajmniej nie kończy się w tym uroczystym i ważnym dla nich i dla wspólnoty zakonnej momencie, lecz jest ona kontynuowana w każdym kolejnym dniu ich życia zakonnego, w obawie przed utratą powołania czy jego kryzysu, które mogą doprowadzić do odejścia ich z zakonu do życia świeckiego.

H. B r y g a łó w n a (1978), Droga rad ewangelicznych. Wprowadzenie do życia zakonnego, Wydawnictwo Akademii Teologii Katolickiej, Warszawa 1978.

4 J.W. G o gola (red.), Formacja zakonna. Życie we wspólnocie zakonnej, 7.7, Kraków 2002; K. D ę b o w s k a, Życie konsekrowane-jego istota i aktualna sytuacja w Polsce; J. B a n i a k, Dynamika nie-kapłańskich powołań zakonnych $w$ Polsce. Studium socjograficzne.

5 J. M aj k a, Socjografia powołań kapłańskich i zakonnych w Europie, Zeszyty Naukowe KUL 3/1960, s. 61-77; S. P r z y b y $1 \mathrm{~s} \mathrm{k} \mathrm{i,} \mathrm{Istota} \mathrm{życia} \mathrm{zakonnego,} \mathrm{Ateneum}$ Kapłańskie 5-6/1967, s. 234-256; H. S i k o r s k a, Wypetnianie woli Bożej droga realizowania powołania zakonnego w Instytucie Sióstr Matki Bożej z Karmelu, Częstochowa 1996; A. C e n c in i, Życie konsekrowane: itinerarium formacyjne $w$ drodze do Emaus. 
Z danych statystycznych i badawczych wynika, że pewien odsetek kandydatów (obojga płci) do życia zakonnego rezygnuje z formacji zakonnej, przeżywając kryzys swego powołania, a następnie opuszcza wspólnotę zakonną. Zdarzają się też sytuacje nietypowe, kiedy kandydaci i kandydatki do życia zakonnego zmieniają zakony i zgromadzenia podczas formacji zakonnej, co jest wywoływane różnymi czynnikami, w tym odszukiwaniem przez nich zakonu odpowiadającego ich oczekiwaniom, w którym mogliby zrealizować swoje powołanie. $Z$ kolei u innych jeszcze kandydatek i kandydatów władze zakonne dostrzegają z biegiem czasu brak powołania i predyspozycji osobowych do niełatwego w swej istocie i celu życia zakonnego, zwłaszcza klauzurowego, i proponują im świadomy powrót do życia świeckiego. Zjawisko to zawsze występowało, jednak pod koniec XX w. nasiliło się bardziej niż w poprzednich okresach, w wyniku czego niektóre zakonnice i niektórzy zakonnicy opuszczali swoje klasztory i powracali do życia świeckiego.

W ostatnim czasie zmniejszyło się zainteresowanie życiem zakonnym wśród dziewcząt i chłopców - bycie zakonnicą i zakonnikiem stało się mniej popularne („nie na dzisiejsze czasy”), czy przestało nadawać sens ich życiu osobistemu, powodując znaczny spadek liczby zgłoszeń kandydatek i kandydatów do wspólnot zakonnych. Obecnie wiele zakonów żeńskich i męskich zgłasza brak nowych powołań, a liczba kandydatek i kandydatów przyjmowanych do ich wspólnot, jak również nowicjuszek i nowicjuszy składających śluby zakonne nie uzupełnia zaistniałych braków kadrowych i nie daje podstaw do optymizmu na przyszłość. ${ }^{6}$ Władze zakonne, znając tę sytuację, w różny sposób starają się wzbudzać zainteresowanie życiem zakonnym w środowiskach młodzieżowych: podczas katechezy szkolnej i parafialnej, rekolekcji dla maturzystek i maturzystów, spotkań sióstr i braci z młodzieżą w parafii w czasie modlitw o powołania zakonne i kapłańskie, odwiedzin młodzieży w zakonach żeńskich i męskich, jak i wielu innych jeszcze okoliczności i sytuacji sprzyjających genezie i rozwojowi powołania zakonnego u młodych osób - dziewcząt i chłopców.?

6 J. B a n i a k, Socjografia nie-kapłańskich powołań zakonnych w Polsce w latach 1900-1994 na tle statystyki powołań zakonnych na świecie, Poznańskie Studia Teologiczne t. 10, 2001, s. 339-365.

7 R. K a c z m a r e k (red.), Zakony i zgromadzenia zakonne $w$ Polsce, Informator, Poznań 1996; E. J a bł oń s k a - D e p t u ła, Zakony i zgromadzenia zakonne w Polsce w XIX i XX wieku, Znak 17/1965, s. 127-143. 
Powstaje więc pytanie, jak przykładowo, kształtowała się liczebność kandydatek i kandydatów do życia zakonnego w Polsce w latach 1964-2017 w świetle dostępnych danych statystycznych. W przypadku zakonów męskich analizą obejmę kandydatów na braci zakonnych, a pominę alumnów-nowicjuszy, gdyż oni stanowią odrębną kategorię kandydatów do życia zakonnego, przygotowując się do przyjęcia święceń kapłańskich. Natomiast bracia zakonni, to mężczyźni, którzy świadomie nie aspirują do otrzymania kapłaństwa, lecz poprzestają na służbie pomocniczej w swoich wspólnotach zakonnych, często wyspecjalizowanej i niezbędnej do ich codziennego funkcjonowania i wykonywania zadań wynikających z własnego charyzmatu zakonnego. Ciągły brak braci zakonnych i słabnące obecnie zainteresowanie społeczne tą formą służby mężczyzny w Kościele i we wspólnocie zakonnej sprzyja osłabianiu funkcjonowania męskich zakonów i zgromadzeń zakonnych i ogranicza ich aktywność zewnętrzną dla dobra społeczności świeckich. Odpowiedź na wyżej postawione pytanie ukazuje tabela 1 .

Tabela 1. Dynamika liczebności sióstr nowicjuszek i braci nowicjuszy w Polsce w latach 1964 -2017

\begin{tabular}{|c|c|c|c|c|}
\hline \multirow{2}{*}{$\begin{array}{c}\text { Okres } \\
\text { badany }\end{array}$} & \multicolumn{4}{|c|}{ Kandydaci do życia zakonnego } \\
\cline { 2 - 5 } & Siostry - Nowicjuszki & \multicolumn{2}{c|}{ Bracia - Nowicjusze } \\
\hline 1964 & 701 & $\mathbf{\%}$ & Liczba & \% \\
\hline 1965 & 685 & $-2,3$ & 53 & 100,0 \\
\hline 1966 & 672 & $-4,1$ & 65 & $+18,5$ \\
\hline 1967 & 679 & $-3,2$ & 58 & $+8,6$ \\
\hline 1968 & 672 & $-4,1$ & 53 & 0,0 \\
\hline 1969 & 673 & $-4,0$ & 57 & $+7,0$ \\
\hline 1970 & 725 & $+3,3$ & 58 & $+8,6$ \\
\hline 1971 & 709 & $+1,1$ & 61 & $+13,1$ \\
\hline 1972 & 725 & $+3,3$ & 62 & $+14,5$ \\
\hline 1973 & 796 & $+11,9$ & 77 & $+31,2$ \\
\hline 1974 & 767 & $+8,6$ & 88 & $+39,8$ \\
\hline 1975 & 698 & $-0,4$ & 76 & $+30,3$ \\
\hline 1976 & 721 & $+2,8$ & 76 & $+30,3$ \\
\hline 1977 & 745 & $+5,9$ & 67 & $+20,9$ \\
\hline 1978 & 823 & $+14,8$ & 95 & $+44,2$ \\
\hline 1979 & 852 & $+17,7$ & 102 & $+48,0$ \\
\hline
\end{tabular}


BIULETYN SOCJOLOGII RELIGII

\begin{tabular}{|c|c|c|c|c|}
\hline \multirow{3}{*}{$\begin{array}{c}\text { Okres } \\
\text { badany }\end{array}$} & \multicolumn{4}{|c|}{ Kandydaci do życia zakonnego } \\
\hline & \multicolumn{2}{|c|}{ Siostry - Nowicjuszki } & \multicolumn{2}{|c|}{ Bracia - Nowicjusze } \\
\hline & Liczba & $\%$ & Liczba & $\%$ \\
\hline 1980 & 915 & $+23,4$ & 143 & $+62,9$ \\
\hline 1981 & 1043 & $+32,8$ & 159 & $+66,7$ \\
\hline 1982 & 1141 & $+38,6$ & 202 & $+73,8$ \\
\hline 1983 & 1332 & $+47,4$ & 235 & $+77,4$ \\
\hline 1984 & 1379 & $+49,2$ & 251 & $+78,9$ \\
\hline 1985 & 1383 & $+49,3$ & 253 & $+79,0$ \\
\hline 1986 & 1525 & $+54,0$ & 241 & $+78,0$ \\
\hline 1987 & 1559 & $+55,0$ & 209 & $+74,6$ \\
\hline 1988 & 1427 & $+50,9$ & 202 & $+74,6$ \\
\hline 1989 & 1359 & $+48,4$ & 203 & $+73,9$ \\
\hline 1990 & 1272 & $+44,9$ & 201 & $+73,6$ \\
\hline 1991 & 1211 & $+42,1$ & 166 & $+68,1$ \\
\hline 1992 & 1229 & $+43,0$ & 194 & $+72,7$ \\
\hline 1993 & 1100 & $+36,3$ & 176 & $+69,9$ \\
\hline 1994 & 1020 & $+31,3$ & 168 & $+68,4$ \\
\hline 1995 & 1037 & $+47,9$ & 174 & $+69,5$ \\
\hline 1996 & 1070 & $+32,4$ & 179 & $+70,4$ \\
\hline 1997 & 1077 & $+34,9$ & 173 & $+69,4$ \\
\hline 1998 & 1112 & $+37,0$ & 156 & $+66,0$ \\
\hline 1999 & 1040 & $+32,6$ & 139 & $+61,9$ \\
\hline 2000 & 924 & $+24,1$ & 108 & $+50,9$ \\
\hline 2001 & 866 & $+19,0$ & 109 & $+51,4$ \\
\hline 2002 & 836 & $+16,1$ & 107 & $+50,5$ \\
\hline 2003 & 778 & $+8,3$ & 105 & $+49,5$ \\
\hline 2004 & 678 & $-2,5$ & 86 & $+44,8$ \\
\hline 2005 & 573 & $-13,9$ & 74 & $+49,0$ \\
\hline 2006 & 600 & $-10,9$ & 93 & $+43,0$ \\
\hline 2007 & 519 & $-19,8$ & 89 & $+40,4$ \\
\hline 2008 & 437 & $-28,6$ & 156 & $+50,0$ \\
\hline 2009 & 385 & $-34,2$ & 139 & $+57,9$ \\
\hline 2010 & 355 & $-37,4$ & 108 & $+53,9$ \\
\hline 2011 & 323 & $-40,9$ & 109 & $+66,7$ \\
\hline 2012 & 275 & $-46,1$ & 107 & $+62,9$ \\
\hline 2013 & 262 & $-47,5$ & 105 & $+61,6$ \\
\hline 2014 & 276 & $-46,0$ & 96 & $+62,9$ \\
\hline 2015 & 273 & $-46,3$ & 104 & $+61,0$ \\
\hline
\end{tabular}


BIULETYN SOCJOLOGII RELIGII

\begin{tabular}{|c|c|c|c|c|}
\hline \multirow{2}{*}{$\begin{array}{c}\text { Okres } \\
\text { badany }\end{array}$} & \multicolumn{4}{|c|}{ Kandydaci do życia zakonnego } \\
\cline { 2 - 5 } & Siostry - Nowicjuszki & \multicolumn{2}{c|}{ Bracia - Nowicjusze } \\
\cline { 2 - 5 } & Liczba & $\mathbf{\%}$ & Liczba & \% \\
\hline 2016 & 220 & $-52,1$ & 128 & $+58,6$ \\
\hline 2017 & 211 & $-53,0$ & 119 & $+55,5$ \\
\hline $\mathbf{1 9 6 4 - 2 0 1 7}$ & $\mathbf{- 2 1 1}$ & $\mathbf{- 5 3 , 0}$ & $+\mathbf{6 6}$ & $+\mathbf{5 5 , 5}$ \\
\hline
\end{tabular}

Źródło: W. Zdaniewicz, Kościót katolicki w Polsce: 1945-1982, Poznań-Ołtarzew 1982, s. 72-75; L. Adamczuk, W. Zdaniewicz (red.), Kościół katolicki w Polsce: 1918-1990,Warszawa 1991, s. 154; Statystyki Konsulty Zakonnej i Komisji Episkopatu Polski ds. Powołań 2010; Serwis informacyjny Konferencji Wyższych Przełożonych Zakonów Męskich w Polsce w latach 2000-2018; Statystyki Konsulty Wyższych Przełożonych Żeńskich Zakonów i Zgromadzeń w Polsce w latach 2000-2018; Obliczenia statystyczne autora opracowania.

Nabór kandydatek do zakonów żeńskich i kandydatów do zakonów męskich w Polsce odznaczał się w przyjęty w okresie 53 lat wyraźną płynnością i znacznym zróżnicowaniem ilościowym. Do zakonów żeńskich zgłosiło się wówczas znacznie więcej kandydatek na siostry niż kandydatów na braci do zakonów męskich. Badania wykazały, że społeczna rola siostry zakonnej w Polsce była wtedy bardziej popularna, atrakcyjniejsza i wyżej społecznie doceniana niż podobna rola brata zakonnego bez aspiracji kapłańskich. O ile w opinii publicznej wstąpienie kobiety do zakonu wyróżnia ją nadal i budzi uznanie wśród ludzi religijnych, o tyle decyzja mężczyzny, zwłaszcza młodego, zostania bratem zakonnym, czyli podjęcia się wypełniania zadań pomocniczych we wspólnocie zakonnej, raczej nie nobilituje go społecznie, a wręcz przeciwnie -pozwala oceniać go, szczególnie przez młodzież, jako „uciekającego przed normalnym życiem”, „bojącego się problemów w świeckim życiu” lub jako „mało ambitnego życiowo”. Rola brata zakonnego obecnie nie cieszy się taką popularnością jak rola siostry zakonnej w rodzinach katolickich, przyczyniając się do znacznie niższej jego oceny w społeczeństwie. W efekcie liczba mężczyzn chcących przyjąć rolę brata w zakonach i zgromadzeniach zakonnych jest ciągle niewielka, a w dodatku nie wszyscy bracia nowicjusze, odbywający już formację 
zakonną, podejmują decyzję o ślubach zakonnych i o trwałym pozostaniu w danej wspólnocie zakonnej. ${ }^{8}$

W pewnym sensie wnioskowi temu przeczą wskaźniki procentowe naboru kandydatek i kandydatów do życia zakonnego w badanym okresie 53 lat. Wskaźniki te są często większe w zakonach męskich, mimo że liczby rzeczywiste sióstr nowicjuszek dominują nad liczbami kandydatów na braci zakonnych. O tej sytuacji decydują liczby kandydatów do życia zakonnego w obu typach wspólnot zakonnych w 1964 r. jako podstawa ustalenia procentowego wskaźnika wzrostu lub spadku tych powołań zakonnych w kolejnych latach tworzących cały badany okres. O ile w globalnym ujęciu w środowisku sióstr nowicjuszek wystąpił regres ich liczby o 53,7\% (różnica między ich wskaźnikiem z 1964 i 2017 r.), o tyle w środowisku braci nowicjuszy wystąpił wzrost ich liczby o 66,4\%. Oczywiście liczby obu typów nowicjuszy zmieniały się w kolejnych latach i dekadach tworzących badane 53 lata.

W tabeli 2 ukażę dynamikę naboru i realizacji powołań zakonnych sióstr i braci w Polsce w przyjętym okresie, dzieląc go umownie na sześć podokresów: 1964-1969; 1970-1979; 1980-1989; 1990 -1999; 2000-2009; 2010-2017. Podział ten ułatwi porównanie wskaźników naboru i realizacji obu typów powołań zakonnych z przyjętych podokresów, a także umożliwi uchwycenie trendów w tym procesie. Liczby nowicjuszek i nowicjuszy z początkowych lat danego podokresu będą stanowiły podstawę ustalenia wskaźnika wzrostu lub spadku tej liczby w tym przedziale czasowym.

\section{Tabela 2. Dynamika naboru i realizacji powołań zakonnych w nowicjatach w Polsce w latach 1964-2017}

\begin{tabular}{|c|c|c|c|c|}
\hline \multirow{2}{*}{$\begin{array}{c}\text { Badany } \\
\text { okres }\end{array}$} & \multicolumn{4}{|c|}{ Kandydaci do życia zakonnego w Polsce } \\
\cline { 2 - 5 } & Siostry - Nowicjuszki & \multicolumn{1}{c|}{ Bracia - Nowicjusze } \\
\cline { 2 - 5 } & Liczba & \% & Liczba & \% \\
\hline $1964-1969$ & -28 & $-4,0$ & +5 & $+8,6$ \\
\hline $1970-1979$ & +127 & $+14,9$ & +54 & $+46,9$ \\
\hline $1980-1989$ & +444 & $+32,7$ & +60 & $+29,6$ \\
\hline $1990-1999$ & -232 & $-18,2$ & -62 & $-30,8$ \\
\hline $2000-2009$ & -569 & $-61,9$ & +7 & $+6,1$ \\
\hline
\end{tabular}

8 J. B a n i a k, Socjografia nie-kapłańskich powołań zakonnych w Polsce w latach 1900-1994 na tle statystyki powołań zakonnych na świecie, s. 345-352. 
BIULETYN SOCJOLOGII RELIGII

\begin{tabular}{|c|c|c|c|c|}
\hline \multirow{2}{*}{$\begin{array}{c}\text { Badany } \\
\text { okres }\end{array}$} & \multicolumn{4}{|c|}{ Kandydaci do życia zakonnego w Polsce } \\
\cline { 2 - 5 } & Siostry - Nowicjuszki & \multicolumn{1}{c|}{ Bracia - Nowicjusze } \\
\cline { 2 - 5 } & Liczba & $\mathbf{\%}$ & Liczba & $\%$ \\
\hline $2010-2017$ & -112 & $-34,7$ & -40 & $-25,2$ \\
\hline $1964-\mathbf{2 0 1 7}$ & $-\mathbf{2 1 1}$ & $\mathbf{- 5 3 , 0}$ & $+\mathbf{6 6}$ & $+\mathbf{5 5 , 5}$ \\
\hline
\end{tabular}

Źródło: L. Adamczuk, W. Zdaniewicz (red.), Kościół katolicki w Polsce: 1918-1990; Statystyki Konsulty Zakonnej i Komisji EP ds. Powołań; Serwis Informacyjny Konferencji Wyższych Przełożonych Zakonów Męskich i Zakonów Żeńskich w Polsce w latach 2000-2018; Obliczenia statystyczne autora opracowania.

Analizując wskaźniki w tabeli 1, widzimy, że w 1964 r. formację zakonną we wszystkich wspólnotach żeńskich odbywało 701 nowicjuszek, a we wspólnotach męskich było 53 kandydatów na braci zakonnych. Po upływie siedmiu lat, czyli w 1969 r., były już 673 nowicjuszki, tak więc liczba ich zmalała o 28, czyli o 4 p. proc. Natomiast kandydatów na braci zakonnych w 1964 r. było 53, a w 1969 r. - 58, czyli więcej o ponad 8 p. proc. W drugim podokresie (1970-1979) nadal widzimy systematyczny wzrost procentowy zarówno sióstr nowicjuszek (o 14,9\%), jak i liczby braci nowicjuszy (o 46,9\%), przy czym w liczbach wzrost ten był większy wśród sióstr (o 127) niż wśród braci (o 54). W trzecim podokresie (1980-1989) nastąpił większy wzrost liczby nowicjuszek (do 444, czyli o 32,7\%) i liczby nowicjuszy (do 60, czyli o 29,6\%). W obu skalach pomiaru można dostrzec znacznie większy wzrost liczby sióstr nad liczbą braćmi nowicjuszy. W czwartym podokresie (lata 1990-1999) wystąpił znaczny spadek liczby kandydatów do życia zakonnego w obu ich kategoriach: wśród sióstr nowicjuszek wyniósł o niemal połowę ich liczby z podokresu trzeciego, o 18,2\% (mniej o 212) oraz wśród braci nowicjuszy o dwie osoby, czyli o 1,2\%. W piątym podokresie (lata 2000-2009) wystąpił ponad trzykrotny spadek liczby sióstr nowicjuszek (o 337) w stosunku do spadku ich liczby w czwartym podokresie, czyli o 43,7\%, i był on największy w całym badanym okresie 53 lat. Z kolei w środowisku braci nowicjuszy wystąpił wtedy wzrost ich liczby o siedem osób w relacji do wskaźnika ujemnego z poprzedniego podokresu, czyli o 6,1\%. W szóstym podokresie (lata 2010-2017) nadal utrzymuje się spadek liczby nowicjuszek i nowicjuszy, aczkolwiek jest on mniejszy w stosunku do wskaźników spadku z piątego podokresu. O ile wśród sióstr nowicjuszek regres ich liczby zmalał do 34,7\%, o tyle wśród 
braci nowicjuszów regres ten wyniósł ponownie $25,2 \% \mathrm{w}$ zestawieniu z dodatnim ich wskaźnikiem z piątego podokresu. ${ }^{9}$

Z jakich środowisk społecznych i lokalnych wywodziły się te powołania zakonne w Polsce w badanym okresie? Statystyki kościelne i wyniki badań socjologicznych poświęcone genezie tych powołań informują, że dominujący odsetek kandydatek na siostrę zakonną $(76,4 \%)$ i jeszcze większy odsetek kandydatów na brata zakonnego $(84,5 \%)$ pochodzi ze środowiska wiejskiego. Natomiast pozostałe ich odsetki wywodzą się z różnej wielkości miast, chociaż dominują tu miasta małe i średnie. Kandydaci do życia zakonnego w obu typach wspólnot zakonnych najliczniej rekrutują się z rodzin wiejsko-rolniczych (kobiety w 58\% i mężczyźni w 64\%), a następnie z rodzin robotniczych (po $20 \% \mathrm{w}$ obu grupach), rzemieślniczych $(10 \%$ i $9 \%$ ), inteligenckich (8\% i 4\%) i innych typów rodzin (4\% i 3\%). W aspekcie religijnym kandydatki i kandydaci do życia zakonnego, przed wstąpieniem do wspólnot zakonnych, byli w dominującej większości osobami głęboko wierzącymi i religijnymi, ściśle związanymi z własnymi parafiami, a także w znacznym odsetku utrzymywali kontakty z tymi zakonami i zgromadzeniami zakonnymi. Te właśnie cechy i uwarunkowania ułatwiły im w dużej mierze podjęcie osobistej decyzji o wyborze życia zakonnego i o wstąpieniu do wybranej wspólnoty zakonnej, jak i trwanie w powołaniu zakonnym. Badania informują też o wpływie innych jeszcze czynników na te powołania zakonne, jak choćby religijność rodziny, poziom zamożności rodziny i jej liczebność, aczkolwiek wpływ ten był już mniej znaczący. ${ }^{10}$

\section{Powołania zakonne sióstr i braci zrealizowane w Polsce w latach 1900-1961}

Liczba nowicjuszek i nowicjuszy jako kandydatów do życia zakonnego wpływa bezpośrednio na stan ilościowy zrealizowanych już powołań zakonnych, czyli na liczebność sióstr i braci, którzy po odbyciu koniecznej wstępnej formacji zakonnej złożyli pierwsze zakonne śluby, a następnie śluby trwałe, wieczyste, stając się pełnoprawnymi członkiniami i członkami wspólnot zakonnych. Na liczebność czy też na stabilność stanu kadrowego

9 Tamże, s. 292-295; J. B a z y l a k, Elementy higieny psychicznej w psychologii pastoralnej, Wyd. Akademii Teologii Katolickiej, Warszawa 1983, s. 257-290.

10 L. A d a m c z u k, W. Z d a n i e w i c z (red.), Kościól katolicki w Polsce: 1918-1990, Warszawa 1991, s. 146-163. 
obu typów wspólnot zakonnych wpływają też siostry i bracia opuszczający je po podjęciu decyzji o rezygnacji z życia zakonnego. Kryzys ilościowy w zakonach jest widoczny najwyraźniej wtedy, gdy maleje liczba nowych zgłoszeń kandydatek i kandydatów do życia zakonnego, a jednocześnie wzrasta liczba kandydatów i kandydatek do życia zakonnego oraz liczba zakonnic i zakonników po ślubach zakonnych opuszczających wspólnoty i powracających do życia świeckiego. Z zakonów częściej występują siostry niż bracia pod wpływem różnych przyczyn i powodów, a w tym wątpliwości w zasadność własnego powołania do życia zakonnego, rozczarowaniem codziennością życia we wspólnocie zakonnej, rozbieżności między własną wizją zakonu i jego obrazem rzeczywistym, trudności w posłuszeństwie przełożonym zakonnym, braku możliwości realizowania osobistych zamiłowań i planów życiowych, zaniku pobożności i wiary w sens służby zakonnej czy też trudności z własną erotyką, seksualnością i potrzeby macierzyństwa a u braci potrzeby ojcostwa. Obecnie oba te zjawiska są widoczne w wielu zakonach i zgromadzeniach zakonnych kobiecych i męskich. ${ }^{11}$

Liczebność sióstr zakonnych po ślubach w latach 1900-1961 według dekad

Zagadnienie zrealizowanych powołań zakonnych sióstr i braci uwzględnię w dalszej analizie dynamiki zakonnych powołań nie-kapłańskich w Polsce w przyjętym okresie. Ukażę w niej liczebność sióstr i braci zakonnych z lat 1900-1961, wykorzystując w tym celu wyniki badań socjologicznych i dostępne dane statystyczne Kościoła rzymskokatolickiego na ten temat z lat 1955-2010. Podstawę dla wskaźników procentowych w kolejnych dekadach stanowi rok rozpoczynający pierwszą dekadę. Sytuację tę ilustrują dane w tabeli 3 .

"I K. F r y z e l, Przyczyny iźródła kryzysów życia zakonnego na drogach odnowy po Soborze Watykańskim II. Na podstawie ksiażki: Angelo Pardilla, La realta Della Vita religiosa, Homo Dei nr 4/2018, s. 70-84. 
Tabela 3. Liczebność sióstr i braci zakonnych po ślubach w Polsce w latach 1900-1961 według podziału na dekady

\begin{tabular}{|c|c|c|c|c|c|c|c|c|}
\hline \multirow{3}{*}{$\begin{array}{l}\text { Zakonnicy } \\
\text { po ślubach }\end{array}$} & \multirow{2}{*}{\multicolumn{2}{|c|}{$\begin{array}{c}\text { 1900-1920 } \\
\text { Dekada }\end{array}$}} & \multirow{2}{*}{\multicolumn{2}{|c|}{$\begin{array}{c}\text { 1921-1940 } \\
\text { Dekada }\end{array}$}} & \multirow{2}{*}{\multicolumn{2}{|c|}{$\begin{array}{c}\text { 1941-1961 } \\
\text { Dekada }\end{array}$}} & \multirow{2}{*}{\multicolumn{2}{|c|}{$\begin{array}{c}\text { Razem } \\
1900-1961\end{array}$}} \\
\hline & & & & & & & & \\
\hline & I. & II. & III. & IV. & V. & VI. & Liczba & $\%$ \\
\hline $\begin{array}{c}\text { Siostry } \\
\text { liczba } \\
\%\end{array}$ & $\begin{array}{c}247 \\
100,0\end{array}$ & $\begin{array}{c}405 \\
+64,0\end{array}$ & $\begin{aligned} & 801 \\
+ & 224,3\end{aligned}$ & $\begin{array}{c}1120 \\
+353,4\end{array}$ & $\begin{array}{c}1013 \\
+310,2\end{array}$ & $\begin{array}{r}1787 \\
+623,5\end{array}$ & 5373 & 88,8 \\
\hline $\begin{array}{c}\text { Bracia } \\
\text { liczba } \\
\%\end{array}$ & $\begin{array}{c}37 \\
100,0\end{array}$ & $\begin{array}{l}35 \\
-5,4\end{array}$ & $\begin{aligned} & 126 \\
+ & 240,5\end{aligned}$ & $\begin{array}{c}159 \\
+329,7\end{array}$ & $\begin{aligned} & 112 \\
+ & 202,7\end{aligned}$ & $\begin{array}{r}207 \\
+459,4\end{array}$ & 676 & 11,2 \\
\hline $\begin{array}{c}\text { Ogółem } \\
\text { liczba } \\
\%\end{array}$ & $\begin{array}{c}284 \\
100,0\end{array}$ & $\begin{array}{c}440 \\
+54,9\end{array}$ & $\begin{aligned} & 927 \\
+ & 226,4\end{aligned}$ & $\begin{array}{c}1279 \\
+350,3\end{array}$ & $\begin{aligned} & 1125 \\
+ & 296,1\end{aligned}$ & $\begin{array}{r}1994 \\
+602,1\end{array}$ & 6049 & 100,0 \\
\hline
\end{tabular}

Źródło: K. Ryczan, Powołania kapłańskie i zakonne w Polsce, w: W. Piwowarski, W. Zdaniewicz (red.), Z badań nad religijnościa polska. Studia i materiaty, Pallottinum, Warszawa-Poznań 1986, s. 169. Obliczenia autora opracowania. Dane z I dekady stanowią tu 100,0\%.

W przyjętym okresie 61 lat liczbowo dominowały siostry zakonne nad braćmi zakonnymi. Różnica między ich wskaźnikami jest duża i wynosi aż 77,6\%, co świadczy o tym, że powołania zakonne sióstr były wzbudzane i realizowane ośmiokrotnie częściej i liczniej niż powołania braci zakonnych. Różnicę tę na korzyść liczebności sióstr zakonnych widać także we wszystkich podokresach i dekadach je tworzących. Przyjmując wskaźniki tych powołań z pierwszej dekady pierwszego okresu za podstawę do ustalenia tempa wzrostu ich liczby w kolejnych dekadach jako $100,0 \%$, można dostrzec $\mathrm{w}$ środowisku sióstr zakonnych systematyczny wzrost ich liczby - zawsze wielokrotny: w drugiej dekadzie przybyło 156 sióstr (o 64,0\%), w trzeciej dekadzie 554 (o 224,3\%), w czwartej dekadzie 873 (o 353,4\%), w piątej dekadzie 766 (o 310,2\%) i w szóstej dekadzie 1540 (o 623,5\%). Liczba braci zakonnych wzrosła dopiero w trzeciej dekadzie o 89 (o 240,5\%), natomiast w następnych dekadach wzrost ten jest już większy: w czwartej dekadzie wynosi 122 (o 329,7\%), w piątej dekadzie 75 (o 202,7\%), zaś w szóstej dekadzie był największy - 170 i wzrósł o 459,4\%. $\mathrm{Z}$ kolei w drugiej dekadzie liczba braci zakonnych zmalała o 2 osoby, czyli o $5,4 \%$. 
W całym badanym okresie 61 lat w Polsce było 6049 powołań zakonnych, w tym dominowały wielokrotnie siostry zakonne $-5373(88,8 \%)$ nad braćmi zakonnymi - 676 (11,2\%). W kolejnych podokresach liczby sióstr kształtowały się następująco: w pierwszym - 652 (12,1\%); w drugim - 1921 $(35,8 \%)$, tj. o 23,7\%; w trzecim - 2800 (52,1\%) tj. więcej o 40,0\%). W populacji braci zakonnych liczby te w kolejnych podokresach były następujące: w pierwszym - 72 (10,6\%); w drugim - 285 (42,2\%, tj. o 31,6\%); w trzecim 319 (47,2\%, tj. o 36,6\% więcej). Liczebność obu typów powołań zakonnych w kolejnych podokresach była następująca: w pierwszym - $724(12,0 \%)$; w drugim - 2206 (36,4\%); w trzecim - 3119 (51,6\%).

Autor badań, K. Ryczan, przypomina, że każdy podokres, a nawet dekady go tworzące, miały własną specyfikę, zależną od wielu różnych czynników, w tym politycznych, społecznych, kulturowych, gospodarczych i kościelnych, które wpływały istotnie na życie religijne Polaków, na ich codzienną egzystencję, byt polityczny i wolność. Sytuacja ta nie pozostawała też obojętna dla procesu wzbudzania, formacji, realizacji i trwania powołań zakonnych, powodując niekiedy regres w ich liczebności. Największy regres liczby sióstr i braci zakonnych zanotowano podczas II wojny światowej i w okresie okupacji hitlerowskiej. Dotyczył on nie tylko liczby księży i alumnów zakonnych, lecz w równej mierze objął liczbę sióstr i braci zakonnych. W latach 1939-1945 zginęło ogółem 580 zakonników mężczyzn, w tym 289 księży (ojców). Z tej liczby 239 stracono w obozach koncentracyjnych (między innymi w Dachau - 94, w Oświęcimie - 68), 218 rozstrzelano, a 123 zaginęło wówczas w innych okolicznościach. Straty te były różne w poszczególnych zakonach i zgromadzeniach zakonnych od jednej osoby u sercanów i paulinów, do 79 (najwięcej) osób u jezuitów, 62 u salezjanów, 60 u franciszkanów konwentualnych. W tym okresie zginęło też z rąk niemieckiego okupanta wiele polskich zakonnic - ogółem śmierć poniosło 289 sióstr, w tym 32 w obozach koncentracyjnych, 121 podczas bombardowań, $7 \mathrm{w}$ więzieniach, 62 rozstrzelano. Straty te były różne w poszczególnych zakonach - od jednej osoby u benedyktynek, dominikanek, felicjanek, franciszkanek, klarysek i oblatek Maryi, do 66 (najwięcej) u szarytek i 36 u sakramentek. W tym okresie wystąpił też regres nowych powołań zakonnych żeńskich i męskich, wywołując znaczny spadek globalnej liczby sióstr i braci zakonnych. Autor badań zaznacza, że polityczna i gospodarcza charakterystyka trzeciego podokresu, czyli lat powojennych i początków budowania w kraju ustroju socjalistycznego, także nie sprzyjał religii i Kościołowi, prowadząc do prześladowania duchowieństwa i spadku 
liczebności powołań zakonnych i kapłańskich. Ówczesnym władzom państwowym i politycznym zależało na jak największym spadku liczby tych powołań, na osłabieniu zainteresowania stanem duchownym i zakonnym w środowisku młodzieży i w społeczeństwie. Starania te częściowo się powiodły, w wyniku czego faktyczna liczba powołań kapłańskich i zakonnych znacznie zmalała. ${ }^{12}$

Proces realizacji i ruch żeńskich powołań zakonnych w latach 1900 -1961

W tabeli 4 ukazuję proces realizacji żeńskich powołań zakonnych w latach 1900-1961 w zakonach klauzurowych oraz czynnych habitowych i bezhabitowych. Zgromadzenia bezhabitowe zachowują regułę zakonną według identycznych ślubów (posłuszeństwa, ubóstwa, czystości), jak zgromadzenia habitowe, lecz ich członkinie nie noszą strojów zakonnych (habitów), tylko ubiory świeckie. Zgromadzenia te uczestniczą aktywnie w życiu Kościoła, parafii i społeczności lokalnych, zachowując jednak styl i tryb życia zakonnego. W tabeli tej ukażę wskaźniki członkiń wspólnot zakonnych po ślubach i wskaźniki odejść kandydatek (nowicjuszek) z formacji zakonnej.

Tabela 4. Realizacja żeńskich powołań zakonnych w Polsce w latach 1900-1961

\begin{tabular}{|l|c|c|c|c|c|c|c|c|}
\hline \multirow{2}{*}{$\begin{array}{l}\text { Typ zakonu } \\
\text { i zgromadzenia }\end{array}$} & \multicolumn{2}{|c|}{ Nowicjuszki } & \multicolumn{2}{c|}{ Pierwsze śluby } & \multicolumn{2}{c|}{ Rezygnacja } & \multicolumn{2}{c|}{ Członkinie } \\
\cline { 2 - 9 } & Liczba & $\%$ & Liczba & $\%$ & Liczba & $\%$ & Liczba & $\%$ \\
\hline Klauzurowe & 2340 & 100,0 & 1827 & 78,1 & 720 & 30,8 & 1620 & 69,2 \\
\hline $\begin{array}{l}\text { Habitowe } \\
\text { czynne }\end{array}$ & 39738 & 100,0 & 32644 & 82,1 & 11361 & 28,6 & 28377 & 71,4 \\
\hline
\end{tabular}

12 J. B a n i a k, Dynamika powołań kapłańskich i zakonnych w Kościele rzymskokatolickim w Polsce w latach 1900-1994. Studium socjograficzne, Nomos, Kraków 1997, s. 97-107; K. R y c z a n, Powołania kapłańskie i zakonne w Polsce, w: W. P i w o w a r s k i, W. Z d a n i e w i c z (red.), Z badań nad religijnościa polska. Studia i materiaty, Pallottinum, Warszawa-Poznań 1986, s. 158-167; L. A d a m c z u k, W. Z d a n i e w i c z (red.), Kościót katolicki w Polsce: 1918-1990, s. 151-152; tabela 5,6 . 
BIULETYN SOCJOLOGII RELIGII

\begin{tabular}{|l|c|c|c|c|c|c|c|c|}
\hline \multirow{2}{*}{$\begin{array}{l}\text { Typ zakonu } \\
\text { i zgromadzenia }\end{array}$} & \multicolumn{2}{|c|}{ Nowicjuszki } & \multicolumn{2}{c|}{ Pierwsze śluby } & \multicolumn{2}{c|}{ Rezygnacja } & \multicolumn{2}{c|}{ Członkinie } \\
\cline { 2 - 10 } & Liczba & $\%$ & Liczba & $\%$ & Liczba & $\%$ & Liczba & $\%$ \\
\hline $\begin{array}{l}\text { Bezhabitowe } \\
\text { czynne }\end{array}$ & 3564 & 100,0 & 3124 & 87,7 & 1207 & 33,9 & 2357 & 66,1 \\
\hline Ogółem & $\mathbf{4 5 6 4 2}$ & $\mathbf{1 0 0 , 0}$ & $\mathbf{3 7 5 9 5}$ & $\mathbf{8 2 , 4}$ & $\mathbf{1 3 2 8 8}$ & $\mathbf{2 9 , 1}$ & $\mathbf{3 2 3 5 4}$ & $\mathbf{7 0 , 9}$ \\
\hline
\end{tabular}

Źródło: W. Zdaniewicz, Wzrost czy kryzys powołań? w: W. Piwowarski, W. Zdaniewicz (red.), Z badań nad religijnościa polska. Studia i materiały, s. 181, tabela 1.

Wskaźniki w tabeli 4 ukazują, że pierwszych ślubów zakonnych (profesji) nie złożyło najwięcej nowicjuszek w zakonach klauzurowych - 513, czyli 21,9\%. W zgromadzeniach czynnych habitowych do ślubów zakonnych nie przystąpiły 7094 nowicjuszki, czyli 17,9\%, a w zgromadzeniach czynnych bezhabitowych - 440 nowicjuszek, czyli 12,3\%. W całym badanym okresie ze ślubów zakonnych zrezygnowało we wszystkich trzech typach zgromadzeń 13288 sióstr, czyli 29,1\% ich stanu ogólnego. Jednakże śluby te złożyły dominujące odsetki nowicjuszek - ogółem 82,4\%, w tym siostry czynne bezhabitowe $-87,7 \%$, a także siostry czynne habitowe $-82,1 \%$. Procentowo najwięcej rezygnacji z życia zakonnego wystąpiło w zgromadzeniach sióstr czynnych bezhabitowych - 33,9\%, na drugim miejscu jest wskaźnik rezygnacji wśród sióstr klauzurowych - 30,8\%, a na trzecim wskaźnik rezygnacji wśród sióstr czynnych habitowych - 28,6\%. Zatem trwałe życie zakonne prowadziło w tym czasie 70,9\% sióstr zakonnych, w tym 71,4\% czynnych habitowych, 69,2\% klauzurowych i 66,1\% czynnych bezhabitowych. Powstaje pytanie, czy trudne warunki życia w zakonach klauzurowych i odmienne uwarunkowania tego życia w zgromadzeniach czynnych bezhabitowych sprzyjają bardziej odejściom zakonnic z tych wspólnot zakonnych niż warunki życia sióstr czynnych habitowych. Być może liczniejsze odejścia sióstr w tych zakonach zostały wywołane innymi jeszcze czynnikami aniżeli kryteria statutowe tych zakonów. Prawdopodobnie kierownictwa zakonów żeńskich znają powody i motywy odejść swoich członkiń z życia zakonnego. Dotarcie do tych informacji i dokonanie analizy powodów rezygnacji dałoby zupełnie nowe spojrzenie na specyfikę życia zakonnego oraz na główne cechy powołania zakonnego. Wprawdzie liczba zakonnic habitowych, które odeszły z życia zakonnego, jest największa (11361), w porównaniu z liczbą rezygnacji w dwóch pozostałych typach zakonów (702) i zgromadzeń (1207), to wskaźniki rezygnacji wynikają z globalnej liczby nowicjuszek i z liczby sióstr, które złożyły pierwsze śluby 
zakonne. Z badań socjologicznych wynika, że o rezygnacji sióstr z życia zakonnego i powrocie do stanu świeckiego decydują przeróżne powody, przyczyny i motywy. Jednak najczęściej odchodzą one ze swoich wspólnot zakonnych ,,po cichu”, bez specjalnego nagłośnienia społecznego, w obawie przed krytyką zakonną czy z lęku przed negatywną oceną własnej rodziny lub katolikami świeckimi z parafii pochodzenia, którzy nie potrafią zrozumieć tej ich decyzji i stanąć po ich stronie. Ciche odejścia kobiet z zakonów i zgromadzeń zakonnych są przeciwieństwem ,głośnych” w większości odejść księży diecezjalnych i zakonnych ze stanu duchownego i ponownych instalacji w życiu świeckim. ${ }^{13}$

Tabela 5. Ruch powołań $w$ żeńskich zgromadzeniach zakonnych w Polsce w latach 1900-1961

\begin{tabular}{|l|c|c|c|c|c|c|c|c|}
\hline \multirow{2}{*}{$\begin{array}{c}\text { Siostry } \\
\text { zakonne }\end{array}$} & \multicolumn{2}{|c|}{ Klauzurowe } & \multicolumn{2}{c|}{$\begin{array}{c}\text { Czynne } \\
\text { habitowe }\end{array}$} & \multicolumn{2}{c|}{$\begin{array}{c}\text { Czynne } \\
\text { bezhabitowe }\end{array}$} & \multicolumn{2}{c|}{ Razem } \\
\cline { 2 - 10 } & Liczba & \% & Liczba & \% & Liczba & $\%$ & Liczba & $\%$ \\
\hline $\begin{array}{l}\text { Przyjęte do } \\
\text { nowicjatu }\end{array}$ & 2340 & 100,0 & 39738 & 100,0 & 3564 & 100,0 & 45642 & 100,0 \\
\hline $\begin{array}{l}\text { Odeszły przed } \\
\text { pierwszymi ślu- } \\
\text { bami zakonnymi }\end{array}$ & 513 & 21,9 & 7094 & 17,9 & 440 & 12,3 & 8047 & 17,6 \\
\hline $\begin{array}{l}\text { Złożyły } \\
\text { pierwsze śluby } \\
\text { zakonne }\end{array}$ & 1827 & 78,1 & 32644 & 82,1 & 3124 & 87,7 & 37595 & 82,4 \\
\hline $\begin{array}{l}\text { Odeszły przed } \\
\text { wieczystymi } \\
\text { ślubami } \\
\text { zakonnymi }\end{array}$ & 164 & 7,0 & 3359 & 8,5 & 631 & 27,7 & 4154 & 9,1 \\
\hline $\begin{array}{l}\text { Złożyły wie- } \\
\text { czyste śluby } \\
\text { zakonne }\end{array}$ & 1663 & 71,1 & 29285 & 73,7 & 2493 & 69,9 & 33441 & 73,3 \\
\hline $\begin{array}{l}\text { Odeszły po wie- } \\
\text { czystych ślubach } \\
\text { zakonnych }\end{array}$ & 43 & 1,8 & 908 & 2,3 & 136 & 3,8 & 1087 & 2,4 \\
\hline
\end{tabular}

13 M. A b r a m o w i c z, Zakonnice odchodza po cichu, Wydawnictwo Krytyki Politycznej, Warszawa 2017; J. B a n i a k, Socjografia nie-kapłańskich powołań zakonnych $w$ Polsce $w$ latach 1900-1994 na tle statystyki powołań zakonnych na świecie. 


\begin{tabular}{|l|c|c|c|c|c|c|c|c|}
\hline \multirow{2}{*}{$\begin{array}{c}\text { Siostry } \\
\text { zakonne }\end{array}$} & \multicolumn{2}{|c|}{ Klauzurowe } & \multicolumn{2}{c|}{$\begin{array}{c}\text { Czynne } \\
\text { habitowe }\end{array}$} & \multicolumn{2}{c|}{$\begin{array}{c}\text { Czynne } \\
\text { bezhabitowe }\end{array}$} & \multicolumn{2}{c|}{ Razem } \\
\cline { 2 - 9 } & Liczba & $\%$ & Liczba & $\%$ & Liczba & $\%$ & Liczba & $\%$ \\
\hline $\begin{array}{l}\text { Wszystkie ode- } \\
\text { szły ze swoich } \\
\text { zakonów }\end{array}$ & 720 & 30,8 & 11361 & 28,6 & 1207 & 33,9 & 13288 & 29,1 \\
\hline $\begin{array}{l}\text { Zostały w swoim } \\
\text { zakonie }\end{array}$ & 1620 & 69,2 & 28377 & 71,4 & 2357 & 66,1 & 32354 & 70,9 \\
\hline
\end{tabular}

Źródło: W. Zdaniewicz, Wzrost czy kryzys powołań? s. 181, tabela 2.

Odejścia sióstr z zakonów różnie kształtowały się w badanym okresie, w zależności od typu ślubów zakonnych. Przed pierwszymi ślubami największy odsetek rezygnujących wystąpił w zakonach klauzurowych (21,9\%), ale już mniejszy odsetek w zgromadzeniach czynnych habitowych $(17,9 \%)$, zaś najmniejszy odsetek w zgromadzeniach czynnych bezhabitowych (12,3\%). Łącznie odeszło wówczas z wszystkich zakonów przed pierwszymi ślubami zakonnymi 17,6\% nowicjuszek. Jeszcze bardziej zróżnicowana była dynamika odejść sióstr przed ślubami wieczystymi (na całe życie): największy ich odsetek był w czynnych zgromadzeniach bezhabitowych (27,7\%), średni odsetek w zgromadzeniach czynnych habitowych $(8,5 \%)$, zaś odsetek najmniejszy w zakonach klauzurowych $(7,0 \%)$. Po złożonych ślubach zakonnych odeszły z zakonów najmniejsze odsetki sióstr: łącznie $-2,4 \%$, w tym w zakonach klauzurowych $-1,8 \%$, w zgromadzeniach czynnych habitowych $-2,3 \%$ i w zgromadzeniach czynnych bezhabitowych $-3,8 \%$.

Liczebność żeńskich powołań zakonnych inaczej kształtowała się w latach 1945-1960. W badaniach okres ten podzielono na trzy pięcioletnie podokresy, aby dokładniej ustalić tempo regresu powołań zakonnych. W pierwszym podokresie ogółem było 4765 sióstr, w drugim - ich liczba zmniejszyła się do 4064 ( do 85,3\%), czyli o 701 sióstr (o 14,7\%), w trzecim - nastąpił dalszy regres do 3938 sióstr (tj. do 82,6\%), czyli o 827 sióstr (o 17,4\%). Regres ten przebiegał odmiennie w poszczególnych zakonach i zgromadzeniach. W drugim podokresie we wszystkich wspólnotach zakonnych ubyło 90 zakonnic (26,0\%), zaś w trzecim - 117 (33,8\%). W czynnych zgromadzeniach habitowych spadek liczby sióstr w drugim podokresie wyniósł 518 osób $(12,6 \%)$ i w trzecim - 627 sióstr $(16,4 \%)$. W zgromadzeniach czynnych bezhabitowych w drugim podokresie ubyły 93 siostry $(29,3 \%)$ i w trzecim podokresie - 38 sióstr $(12,0 \%)$. Natomiast w całym 
badanym okresie liczba sióstr zakonnych zmniejszyła się o 827 osób, czyli o $17,4 \%$ ich populacji. ${ }^{14}$

Globalna liczba sióstr i braci zakonnych po ślubach w latach 1955-2017

W tabeli 6 ukażę globalną liczbę sióstr profesek i braci po ślubach z wszystkich zakonów i zgromadzeń z lat 1955-2017, wykorzystując w tym celu dostępne kościelne statystyki powołań zakonnych. Należy zaznaczyć, że jedynie Kościół sporządza i gromadzi te statystyki, podobnie jak statystyki powołań kapłańskich - alumnów seminariów duchownych oraz księży diecezjalnych i zakonnych. Ze względu na to, że nie ma ich w innych źródłach, prowadząc badania na ten temat, trzeba korzystać ze statystyk istniejących w źródłach kościelnych.

Tabela 6. Siostry i bracia zakonni w Polsce po ślubach w latach 1955-2017

\begin{tabular}{|c|c|c|c|c|c|c|c|c|}
\hline \multirow{2}{*}{$\begin{array}{c}\text { Okres } \\
\text { badany }\end{array}$} & \multicolumn{2}{|c|}{ Zakony i zgromadzenia żeńskie } & \multicolumn{2}{|c|}{ Siostry zakonne } & \multicolumn{2}{c|}{$\begin{array}{c}\text { Zakony } \\
\text { męskie }\end{array}$} \\
\cline { 2 - 10 } & $\mathbf{C z y n n e ~ r a z e m ~}$ & \multicolumn{2}{|c|}{ Klauzurowe } & \multicolumn{2}{|c|}{ Ogółem } & \multicolumn{2}{c|}{$\begin{array}{c}\text { Bracia po } \\
\text { ślubach }\end{array}$} \\
\cline { 2 - 10 } & Liczba & $\%$ & Liczba & $\%$ & Liczba & $\%$ & Liczba & $\%$ \\
\hline 1955 & 24450 & 100,0 & 1141 & 100,0 & 25591 & 100,0 & 1803 & 100,0 \\
\hline 1956 & 24919 & $+1,9$ & 1144 & $+0,3$ & 26053 & $+1,8$ & 1843 & $+2,2$ \\
\hline 1957 & 26451 & $+8,2$ & 1194 & $+4,8$ & 27645 & $+8,0$ & 1890 & $+4,8$ \\
\hline 1958 & 25150 & $+2,9$ & 1246 & $+9,2$ & 26396 & $+3,1$ & 1865 & $+3,4$ \\
\hline 1959 & 25502 & $+4,3$ & 1340 & $+17,4$ & 26842 & $+4,9$ & 1830 & $+1,5$ \\
\hline 1960 & 25672 & $+5,0$ & 1392 & $+22,0$ & 27064 & $+5,7$ & 1775 & $-1,6$ \\
\hline 1961 & 26063 & $+6,6$ & 1229 & $+7,7$ & 27392 & $+7,0$ & 1775 & $-1,6$ \\
\hline 1962 & 26230 & $+7,3$ & 1295 & $+13,5$ & 27525 & $+7,5$ & 1794 & $-0,5$ \\
\hline 1963 & 26190 & $+7,1$ & 1335 & $+17,0$ & 27525 & $+7,5$ & 1784 & $-1,1$ \\
\hline 1964 & 26330 & $+7,7$ & 1227 & $+7,5$ & 27445 & $+7,2$ & 1738 & $-3,6$ \\
\hline 1965 & 26252 & $+7,4$ & 1335 & $+17,0$ & 27587 & $+7,8$ & 1723 & $-4,4$ \\
\hline 1966 & 25949 & $+6,1$ & 1313 & $+15,0$ & 27262 & $+6,5$ & 1690 & $-5,8$ \\
\hline 1967 & 25650 & $+4,9$ & 1281 & $+12,3$ & 26931 & $+5,2$ & 1662 & $-7,8$ \\
\hline 1968 & 25754 & $+5,3$ & 1331 & $+16,6$ & 27085 & $+5,8$ & 1636 & $-9,3$ \\
\hline 1969 & 25383 & $+3,8$ & 1308 & $+14,6$ & 26691 & $+4,3$ & 1628 & $-9,7$ \\
\hline
\end{tabular}

${ }_{14}$ W. Z d a n i e w i c z, Wzrost czy kryzys powolań? w: W. P i wow a r sk i, W. Z d a n i e w i z (red.), Z badań nad religijnościa polska. Studia i materiaty, s. 183. 
BIULETYN SOCJOLOGII RELIGII

\begin{tabular}{|c|c|c|c|c|c|c|c|c|}
\hline \multirow{3}{*}{$\begin{array}{c}\text { Okres } \\
\text { badany }\end{array}$} & \multicolumn{4}{|c|}{ Zakony i zgromadzenia żeńskie } & \multirow{2}{*}{\multicolumn{2}{|c|}{$\begin{array}{c}\text { Siostry zakonne } \\
\text { Ogółem }\end{array}$}} & \multirow{2}{*}{\multicolumn{2}{|c|}{$\begin{array}{c}\begin{array}{c}\text { Zakony } \\
\text { męskie }\end{array} \\
\text { Bracia po } \\
\text { ślubach }\end{array}$}} \\
\hline & \multicolumn{2}{|c|}{ Czynne razem } & \multicolumn{2}{|c|}{ Klauzurowe } & & & & \\
\hline & Liczba & $\%$ & Liczba & $\%$ & Liczba & $\%$ & Liczba & $\%$ \\
\hline 1970 & 25546 & $+4,5$ & 1321 & $+15,8$ & 26867 & $+5,0$ & 1610 & $-10,7$ \\
\hline 1971 & 25546 & $+3,6$ & 1307 & $+14,5$ & 26633 & $+4,0$ & 1559 & $-13,5$ \\
\hline 1972 & 24988 & $+2,2$ & 1291 & $+13,1$ & 26280 & $+2,7$ & 1561 & $-13,4$ \\
\hline 1973 & 24881 & $+1,8$ & 1288 & $+12,9$ & 26169 & $+2,2$ & 1547 & $-14,2$ \\
\hline 1974 & 24632 & $+0,7$ & 1270 & $+11,3$ & 25902 & $+1,2$ & 1527 & $-15,3$ \\
\hline 1975 & 24387 & $+0,3$ & 1292 & $+13,2$ & 25679 & $+0,3$ & 1401 & $-22,3$ \\
\hline 1976 & 24321 & $-0,5$ & 1256 & $+10,1$ & 25577 & $-0,1$ & 1458 & $-19,1$ \\
\hline 1977 & 24257 & $-0,8$ & 1247 & $+9,3$ & 25504 & $-0,4$ & 1413 & $-21,6$ \\
\hline 1978 & 24058 & $-1,6$ & 1255 & $+10,0$ & 25313 & $-1,1$ & 1399 & $-22,5$ \\
\hline 1979 & 23830 & $-2,5$ & 1246 & $+9,2$ & 25076 & $-2,1$ & 1400 & $-22,4$ \\
\hline 1980 & 23686 & $-3,2$ & 1241 & $+8,8$ & 24927 & $-2,4$ & 1425 & $-21,0$ \\
\hline 1981 & 23582 & $-3,6$ & 1245 & $+9,1$ & 24827 & $-3,0$ & 1385 & $-23,3$ \\
\hline 1982 & 23458 & $-4,0$ & 1265 & $+10,8$ & 24723 & $-3,4$ & 1406 & $-22,0$ \\
\hline 1983 & 23674 & $-3,2$ & 1274 & $+11,7$ & 24948 & $-2,5$ & 1427 & $-20,9$ \\
\hline 1984 & 23594 & $-3,5$ & 1263 & $+10,7$ & 24857 & $-2,9$ & 1511 & $-16,2$ \\
\hline 1985 & 23329 & $-4,6$ & 1309 & $+14,7$ & 24638 & $-3,7$ & 1546 & $-14,3$ \\
\hline 1986 & 22865 & $-6,5$ & 1353 & $+18,6$ & 24218 & $-5,4$ & 1549 & $-14,1$ \\
\hline 1987 & 22868 & $-6,4$ & 1543 & $+35,2$ & 24411 & $-4,6$ & 1556 & $-13,7$ \\
\hline 1988 & 22942 & $-6,2$ & 1417 & $+24,2$ & 24359 & $-4,8$ & 1587 & $-12,0$ \\
\hline 1989 & 24043 & $-1,7$ & 1309 & $+14,7$ & 25352 & $-0,9$ & 1565 & $-13,2$ \\
\hline 1990 & 24032 & $-1,8$ & 1487 & $+30,0$ & 25519 & $-0,3$ & 1524 & $-15,5$ \\
\hline 1991 & 24089 & $-1,5$ & 1374 & $+20,4$ & 25463 & $-0,5$ & 1464 & $-18,8$ \\
\hline 1992 & 23166 & $-5,2$ & 1279 & $+12,1$ & 24445 & $-4,5$ & 1419 & $-21,3$ \\
\hline 1993 & 23362 & $-4,4$ & 1294 & $+13,4$ & 24656 & $-3,6$ & 1372 & $-23,9$ \\
\hline 1994 & 23397 & $-4,3$ & 1316 & $+14,3$ & 24713 & $-4,3$ & 1357 & $-24,7$ \\
\hline 1995 & 22664 & $-7,3$ & 1354 & $+18,7$ & 24018 & $-6,2$ & 1320 & $-26,7$ \\
\hline 1996 & 23374 & $-4,4$ & 1372 & $+20,2$ & 24746 & $-3,3$ & 1323 & $-26,6$ \\
\hline 1997 & 22886 & $-6,4$ & 1364 & $+19,5$ & 14250 & $-5,2$ & 1409 & $-21,8$ \\
\hline 1998 & 22822 & $-6,7$ & 1345 & $+17,9$ & 24167 & $-5,6$ & 1445 & $-28,2$ \\
\hline 1999 & 22886 & $-6,4$ & 1372 & $+20,2$ & 24258 & $-5,2$ & 1394 & $-22,6$ \\
\hline 2000 & 21926 & $-10,3$ & 1314 & $+15,2$ & 23240 & $-9,2$ & 1393 & $-22,7$ \\
\hline 2001 & 21581 & $-11,7$ & 1306 & $+14,5$ & 22887 & $-10,4$ & 1363 & $-24,4$ \\
\hline 2002 & 21661 & $-11,4$ & 1331 & $+16,6$ & 22992 & $-10,2$ & 1374 & $-23,8$ \\
\hline 2003 & 21269 & $-13,0$ & 1328 & $+16,4$ & 22597 & $-11,7$ & 1325 & $-26,5$ \\
\hline
\end{tabular}


BIULETYN SOCJOLOGII RELIGII

\begin{tabular}{|c|c|c|c|c|c|c|c|c|}
\hline \multirow{3}{*}{$\begin{array}{c}\text { Okres } \\
\text { badany }\end{array}$} & \multicolumn{4}{|c|}{ Zakony i zgromadzenia żeńskie } & \multirow{2}{*}{\multicolumn{2}{|c|}{$\begin{array}{c}\text { Siostry zakonne } \\
\text { Ogólem }\end{array}$}} & \multirow{2}{*}{\multicolumn{2}{|c|}{\begin{tabular}{|c|}
$\begin{array}{c}\text { Zakony } \\
\text { męskie }\end{array}$ \\
Bracia po \\
ślubach \\
\end{tabular}}} \\
\hline & \multicolumn{2}{|c|}{ Czynne razem } & \multicolumn{2}{|c|}{ Klauzurowe } & & & & \\
\hline & Liczba & $\%$ & Liczba & $\%$ & Liczba & $\%$ & Liczba & $\%$ \\
\hline 2004 & 20945 & $-14,3$ & 1310 & $+14,8$ & 22255 & $-13,0$ & 1262 & $-36,0$ \\
\hline 2005 & 20686 & $-15,4$ & 1323 & $+15,9$ & 22009 & $-14,0$ & 1335 & $-25,9$ \\
\hline 2006 & 20301 & $-17,0$ & 1351 & $+18,4$ & 21652 & $-15,4$ & 1303 & $-27,7$ \\
\hline 2007 & 19855 & $-18,8$ & 1364 & $+19,5$ & 21219 & $-17,1$ & 1259 & $-30,7$ \\
\hline 2008 & 19513 & $-20,2$ & 1383 & $+21,2$ & 20896 & $-18,3$ & 1236 & $-31,4$ \\
\hline 2009 & 19150 & $-21,7$ & 1376 & $+20,6$ & 20526 & $-19,8$ & 1287 & $-28,6$ \\
\hline 2010 & 18840 & $-22,9$ & 1368 & $+19,9$ & 20208 & $-21,0$ & 1166 & $-35,3$ \\
\hline 2011 & 18664 & $-23,7$ & 1204 & $+5,5$ & 19868 & $-22,4$ & 1156 & $-35,9$ \\
\hline 2012 & 18323 & $-25,0$ & 1215 & $+6,5$ & 19538 & $-23,6$ & 1142 & $-36,7$ \\
\hline 2013 & 18018 & $-26,3$ & 1228 & $+7,6$ & 19246 & $-24,8$ & 1153 & $-36,0$ \\
\hline 2014 & 17686 & $-27,7$ & 1239 & $+8,6$ & 18925 & $-26,0$ & 1145 & $-36,5$ \\
\hline 2015 & 17330 & $-29,1$ & 1217 & $+6,7$ & 18547 & $-27,5$ & 1176 & $-34,8$ \\
\hline 2016 & 17008 & $-30,4$ & 1189 & $+4,2$ & 18197 & $-28,9$ & 1181 & $-34,5$ \\
\hline 2017 & 16684 & $-31,8$ & 1174 & $+2,9$ & 17858 & $-30,2$ & 1172 & $-35,0$ \\
\hline $\begin{array}{c}1955- \\
2017 \\
\end{array}$ & -16684 & $-31,8$ & +1174 & $+2,9$ & -7733 & $-30,2$ & -631 & $-35,0$ \\
\hline
\end{tabular}

Źródło: W. Zdaniewicz, Kościół katolicki w Polsce: 1982, s. 74-75; L. Adamczuk, W. Zdaniewicz, (red.), Kościół katolicki w Polsce: 1918-1990, s. 154; L. Adamczuk, W. Zdaniewicz, H,S. Zaręba (red.), Statystyka diecezji Kościoła katolickiego w Polsce: 1992-2004, s. 56, tabela 9, s. 57, tabela 10; Ośrodek Statystyki Kościoła w Watykanie: 2005-2010; W. Zdaniewicz, W. Sadłoń (red.), Duchowieństwo diecezjalne oraz członkowie męskich instytucji życia konsekrowanego i stowarzyszeń życia apostolskiego: 2011, ISKK, Warszawa 2011; Statystyki Powołań Przełożonych Zakonów Męskich i Żeńskich w Polsce w latach 200-2017; Obliczenia autora opracowania.

Analiza wskaźników zamieszczonych w tabeli 6 ukazuje, że liczebność sióstr i braci zakonnych w przyjętym okresie 1955-2017 była bardzo zróżnicowana. Dynamikę tę można najlepiej dostrzec, dzieląc przyjęty okres na krótsze podokresy uwzględniające kolejne lata: 50., 60., 70., 80., 90. XX w. oraz lata pierwszej i drugiej dekady XXI w. Niepełny jest podokres pierwszy, ponieważ brak w nim danych dotyczących powołań z jego pierwszej połowy (1950 r.) oraz danych z trzech lat drugiej dekady obecnego wieku. 
Pierwszy podokres stanowi więc druga połowa lat 50. XX w., przy końcu którego widzimy wzrost liczby sióstr zakonnych obu typów o 4,9\%, w zestawieniu z ich liczbą z 1955 r. (traktowaną jako podstawa ustalenia wskaźników wzrostu lub spadku liczby sióstr w kolejnych podokresach), w tym czynnych o 4,3\% i klauzurowych o 17,4\%. Okres ten ze względów politycznych i ideologicznych był trudny dla funkcjonowania Kościoła w Polsce Ludowej - władza socjalistyczna planowała pełną laicyzację i ateizację społeczeństwa, chcąc zupełnie usunąć wiarę i religię z życia codziennego jednostek i grup społecznych. Sytuacja ta dotknęła także duchowieństwo oraz proces rekrutacji i formacji powołań kapłańskich i zakonnych, przyczyniając się do stopniowego spadku ich liczby. Jednak Kościół skutecznie pokonywał ów opór i presję socjalistycznego państwa i władzy, stwarzając powołaniom dogodne warunki do budzenia się i rozwoju, zwłaszcza w środowisku rodzinnym, broniąc dostępu wiernych do praktyk religijnych, a dzieciom i młodzieży, spośród której wywodziły się też żeńskie i męskie powołania zakonne, do lekcji religii.

W drugim, pełnym, podokresie (lata 60 . XX w.) nadal występowała trudna sytuacja polityczna dla Kościoła i powołan duchownych, w tym zakonnych. Władze świeckie w różny sposób zniechęcały młodych ludzi od wybierania kariery zakonnej. Jednak wbrew tej akcji utrzymała się tendencja wzrostowa liczby sióstr zakonnych, chociaż była ona już słabsza w porównaniu ze wskaźnikami wzrostu z pierwszego podokresu. Wzrost tej liczby sióstr wynosił wtedy $4,3 \%$, w tym w populacji sióstr czynnych $3,8 \%$ i w populacji sióstr klauzurowych $14,6 \%$.

W trzecim podokresie (lata 70. XX w.) następowały nowe sytuacje i zdarzenia społeczno-polityczne w państwie, zaczęła budzić się świadomość wolnościowa społeczeństwa, dążenie do odzyskania suwerenności państwowej i wola poprawy losu ludzi pracy. Władza państwowa i polityczna zaczęła tracić autorytet społeczny. W walkę o prawa ludzi włączył się Kościół i duchowieństwo, otwierając wiernym drogę do odzyskiwania własnych praw i wolności, w tym religijnej. Władza świecka jednak nie była chętna do dialogu z Kościołem i ze społeczeństwem odmawiającym jej posłuszeństwa. Sytuacja ta nie była korzystna dla powołań zakonnych i kapłańskich, a w jej efekcie liczebność sióstr była już bardziej wahliwa, zmienna. W latach 1970-1974 miała ona tendencję pozytywną, aczkolwiek stopniowo malejącą, natomiast w kolejnych latach (1975-1979) widać już stopniowy spadek liczby sióstr czynnych o 2,5\%, zaś globalna liczba tych sióstr wzrastała nierównomiernie, na przykład w 1970 r. o 15,8\% a w 1979 r. 
już tylko 9,2\%. W tym podokresie wystąpił wzrost liczby sióstr klauzurowych o $10 \%$.

W czwartym podokresie (lata 80. XX w.), w wyniku kolejnych zmian społeczno-politycznych i ekonomicznych w państwie, a także w mentalności społecznej, w tym dotyczącej poziomu życia religijnego i pozycji Kościoła, nastąpił dalszy, stopniowy spadek liczby powołań sióstr czynnych, aczkolwiek był o już znaczniej zróżnicowany, wynosząc pod koniec tego podokresu 1,7\%. Tendencję spadkową widać też w globalnej liczbie wszystkich sióstr zakonnych w tym podokresie - w 1989 r. było już mniej o $0,9 \%$. Z kolei w populacji sióstr klauzurowych wystąpił wówczas wzrost ich liczby, przy czym największy był 1987 r. - o 35,2\%.

W piątym podokresie (lata 90. XX w.), mimo sprzyjających warunków politycznych w państwie i zdecydowanie lepszej sytuacji Kościoła, nadal utrzymywała się spadkowa tendencja w liczebności sióstr czynnych (o 6,4\%), natomiast liczba sióstr klauzurowych wzrosła wtedy o $20,2 \%$. Jednak globalna liczba wszystkich sióstr zmniejszyła się w tym podokresie o $5,2 \%$.

W szóstym podokresie (pierwszej dekadzie XXI w.) w populacji sióstr czynnych wystąpił największy regres, sięgający w $2010 \mathrm{r}$. 17,5\% w zestawieniu z ich liczbą z $1955 \mathrm{r}$. W populacji sióstr klauzurowych w latach 2000-2003 widać dalszy znaczący wzrost ich liczby, sięgający 23,0\%, jednak w kolejnych latach tego podokresu powoli on malał, by w 2010 r. osiągnąc zaledwie 19,9\% (spadek o 12,7\% w porównaniu z liczbą z 2000 r.). W drugiej dekadzie obecnego wieku zwiększył się znacznie regres liczby sióstr czynnych, sięgając niemal jednej trzeciej ich populacji w 2017 r. Podobną sytuację spadek widać także w populacji braci zakonnych. Jedynie niewielki wzrost odsetka powołań był widoczny w populacji sióstr klauzurowych (o niespełna $35 \mathrm{w}$ porównaniu $\mathrm{z}$ ich wskaźnikiem z lat 50. ubiegłego wieku). Wzrost liczby tych powołań kobiecych był widoczny w całym okresie 62 lat, zaś ciągły spadek powołań wystąpił wówczas w populacji braci zakonnych, sięgający przy końcu tego okresu jednej trzeciej.

W całym badanym okresie 62 lat łączna liczba sióstr zakonnych zmniejszyła się o 4055 (o 15,8\%), w tym sióstr czynnych o 4282 (o 17,5\%). Natomiast liczba sióstr klauzurowych wzrosła o 227 (o19,9\%). Należy zaznaczyć, że każdy z tych podokresów odznaczał się odmiennymi cechami, był uwarunkowany różnymi czynnikami, w tym politycznymi, społecznymi, gospodarczymi, kulturowymi, które miały bezpośredni wpływ na sprawy Kościoła w Polsce, na religijność i moralność katolików, nie pomijając 
również środowisk zakonnych. Liczebność powołań zakonnych, zwłaszcza ich nabór i formacja, jest w pewnym sensie odzwierciedleniem specyfiki każdego z tych podokresów, a także całego okresu - jest ona wtedy zmienna, często płynna i mało stabilna, z tendencją systematycznie malejącą.

Nieco inaczej kształtowała się w tym okresie liczebność braci zakonnych. Tendencję progresywną widać wyłącznie w pierwszym podokresie, aczkolwiek dość zróżnicowaną, osiągającą w 1959 r. zaledwie 1,5\%, z porównaniu z ich liczbą z $1955 \mathrm{r}$. W kolejnych podokresach w liczebności braci zakonnych można zauważyć wyraźny regres. W latach 60 . XX w. osiągnął on $9,7 \%$, a w latach 70 . aż $22,4 \%$ (czyli wzrósł o 13 p. proc.); natomiast w latach 80 . był on zmienny, a w 1989 r. osiągnął 13,2\% (spadek o 9 p. proc.). $\mathrm{Z}$ kolei w latach 90. regres liczby braci wzrastał systematycznie, a 1999 r. osiągnął $28,2 \%$ (wzrost o 15 p. proc.). W obecnym wieku spadek liczby braci zakonnych jest największy, w porównaniu z ich liczbą w poprzednich podokresach, zwłaszcza z pierwszym, osiągając w 2010 r. aż 35,3\% w porównaniu z liczbą braci w $1955 \mathrm{r}$. Łącznie w badanym okresie 62 lat liczba braci zakonnych zmniejszyła się o 631, czyli o $35 \%$.

Wspomniane wyżej cechy i uwarunkowania kolejnych podokresów, jak i całego okresu, w odniesieniu do liczebności sióstr zakonnych, mają też pełne zastosowanie do dynamiki liczebności braci zakonnych - wpływały one na jej fluktuację, zmienność bądź stabilność. Sytuację tę ukazuje tabela 7, uwzględniająca wskaźniki globalne powołań zakonnych z kolejnych podokresów.

Jeśli liczbę sióstr i braci zakonnych, ujętą $\mathrm{w}$ tabeli 7 , z roku rozpoczynającego dany okres przyjmiemy jako podstawę ustalenia jej dynamiki w czasie jego trwania, zauważymy, że dynamika ta była bardzo zróżnicowana, ukazując albo regres albo progres tej liczby obu typów powołań zakonnych.

W latach 50. XX w. wystąpił wzrost zarówno liczby sióstr zakonnych obu formacji, aczkolwiek kilkakrotnie większy (o 13,1\%) w populacji sióstr kontemplacyjnych, jak i wzrost liczby braci zakonnych (o 1,5\%). W latach 60. XX w. wystąpił spadek liczby powołań zakonnych w obu formacjach sióstr, chociaż był on większy wśród sióstr klauzurowych (o 4,9\%), zmalała także liczba braci zakonnych (o 8,3\%). Analogiczną sytuację liczebności sióstr i braci zakonnych można zauważyć w latach 70 . XX w., aczkolwiek regres ten był już znacznie większy - wśród sióstr wyniósł on ogółem $6,7 \%$, a wśród braci zakonnych - $13 \%$. Z kolei w latach 80 . XX w. nastąpił ponowny wzrost liczby powołań w obu typach zakonów - w populacji sióstr o 1,7\% (w tym większy u sióstr klauzurowych $-5,5 \%$ ), a w populacji braci zakonnych $-9,8 \%$. Lata 90 . XX w. przyniosły spadek zarówno liczby sióstr 
zakonnych - ogółem o 4,9\%, w tym o 7,7\% sióstr klauzurowych i o 4,8\% sióstr czynnych, jak i spadek liczby braci zakonnych aż o 15\%. Regres liczby obu formacji zakonnych pogłębił się znacznie w pierwszej dekadzie obecnego wieku - w populacji sióstr zakonnych wyniósł on łącznie 13,1\%, w tym wśród sióstr czynnych 13,3\% i wśród sióstr klauzurowych 9,6\%, natomiast w populacji braci zakonnych wyniósł on $18,4 \%$.

$\mathrm{Z}$ danych tych wynika, że w przyjętym okresie najmniejszą popularnością cieszyła się w Polsce rola brata zakonnego wśród młodych i starszych mężczyzn. $Z$ tego powodu tak niewielkie, w porównaniu z liczbą sióstr zakonnych, były liczby braci zakonnych w kolejnych podokresach, a także w całym okresie. W 2009 r. było w Polsce łącznie 1287 braci zakonnych, w tym najwięcej w diecezjach: krakowskiej (210), warszawskiej (179), poznańskiej (80), częstochowskiej (68), zaś najmniej w diecezji: ełckiej i zamojsko-lubaczowskiej - po jednym bracie. Największą liczbę braci miały bonifratrzy (75), bracia serca Jezusowego (52), jezuici (51), pallotyni (50), bracia szkolni (61), paulini (48). W pozostałych zakonach i zgromadzeniach męskich były już mniejsze liczby braci - od jednego (bazylianie) do 40 (albertyni). Bardzo zróżnicowana była struktura wieku braci zakonnych do 30 lat życia (7,3\%), od 31 do 40 lat życia (22,8\%), od 41 do 50 lat życia (31,4\%), od 51 do 60 lat życia (15,4\%), powyżej 60 lat życia było $23,0 \%$ braci. Najliczniejszą więc grupę wiekową stanowią bracia liczący od 31 do 50 lat życia $(54,2 \%)$, zaś na drugim miejscu są bracia liczący od 51 do 60 lat życia (38,4\%). Młodzi wiekiem bracia zakonni, czyli mający mniej niż 30 lat, są zdecydowaną mniejszością w zakonach polskich, stanowią bowiem zaledwie $7,3 \%$ całej ich populacji. ${ }^{15}$

15 W. Z d a n i e w i c z, W. S a dłoń (red.), Duchowieństwo diecezjalne oraz członkowie męskich instytucji życia konsekrowanego i stowarzyszeń życia apostolskiego: 2011, ISKK, Warszawa 2011, s. 15-17. 
BIULETYN SOCJOLOGII RELIGII

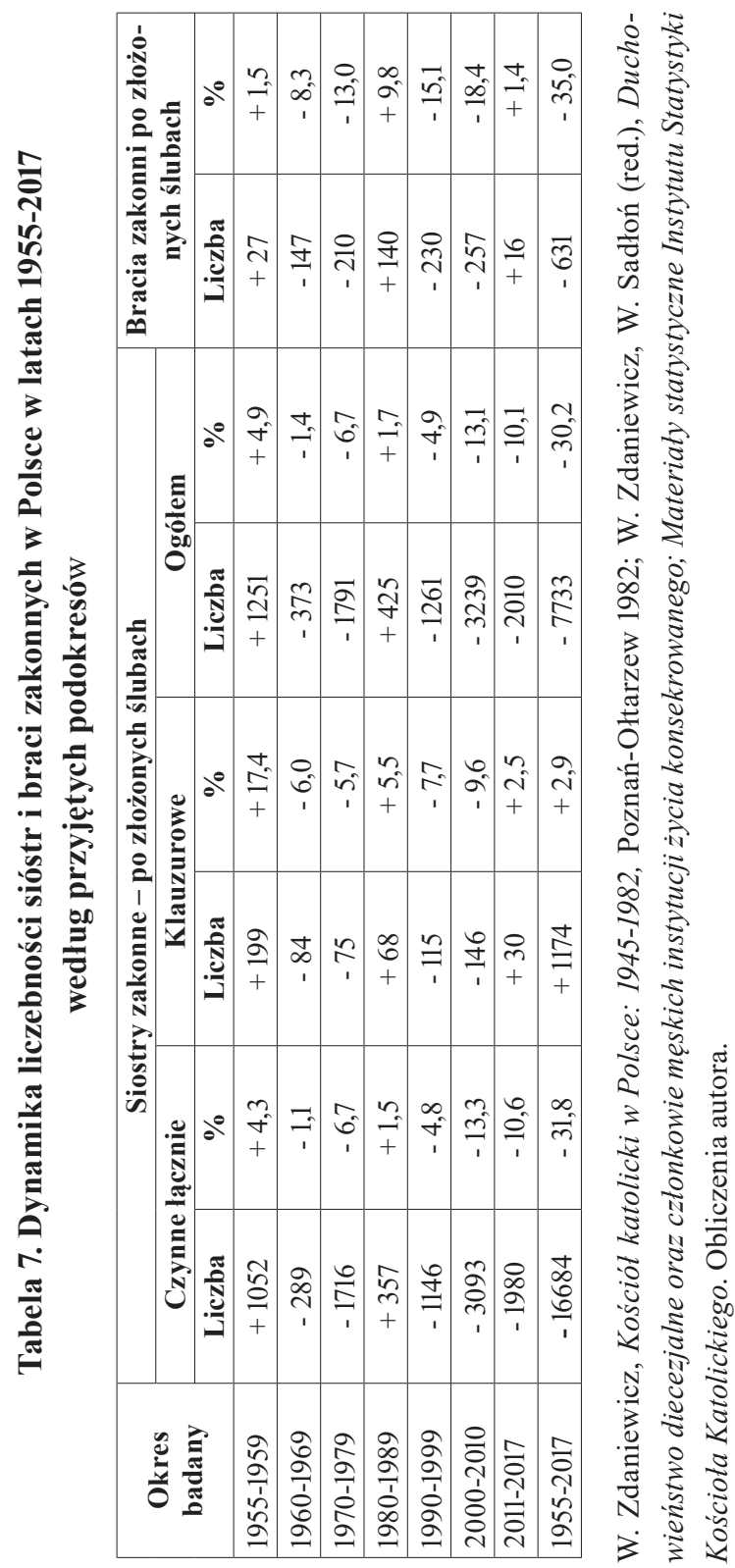


Diecezjalna i zakonna dyslokacja sióstr i braci zakonnych w Polsce w latach 2005-2017

Ważna poznawczo jest też kwestia dyslokacji sióstr i braci zakonnych w poszczególnych diecezjach Kościoła rzymskokatolickiego w Polsce, w obecnym jego podziale diecezjalnym, w przyjętym tu okresie lat 2005-2017. Dane dotyczące tej dyslokacji powołań zakonnych w diecezjach są dostępne w statystykach kościelnych.

Wskaźniki zamieszczone w tabeli 8 informują, że liczebność sióstr i braci zakonnych w poszczególnych diecezjach Kościoła rzymskokatolickiego w Polsce była w tym okresie, a także w kolejnych latach tworzących ten okres, dość zróżnicowana. Liczba sióstr w każdej diecezji jest zdecydowanie większa od liczby braci zakonnych. W kilku diecezjach liczba sióstr zakonnych przekraczała 2000, co dotyczy diecezji krakowskiej - w 2005 r. było ich tu 2 807, a w 2010 r. - 2700 (spadek o 4,8\%) i w diecezji warszawskiej- 2235 (spadek o 18,7\%). W kilku diecezjach liczba sióstr zakonnych przekroczyła 1000 osób, a mianowicie w diecezji warszawsko-praskiej w 2005 r. było ich 1412, a w 2017 r. - 1356 (spadek o 3,2\%); w poznańskiej 1302 wobec 920 w 2017 r. (spadek o 29,3\%); przemyskiej - 1100 wobec 1057 (spadek o 0,3\%); tarnowskiej - 1070 wobec 950 (regres o 11,2\%). Liczbę sióstr zbliżoną do tysiąca osób osiągnęły następujące diecezje: wrocławska w 2005 r. (953) i w 2017 r. (832), częstochowska (869); katowicka (843), opolska (834).

Biorąc pod uwagę cały badany okres, zauważamy, że tylko w kilku diecezjach wystąpił wzrost liczby sióstr o znikome odsetki: w katowickiej o 6,5\%; w koszalińsko-kołobrzeskiej o 2,7\%; w ełckiej o 2,3\%; w kaliskiej o $1,0 \%$; w tarnowskiej o $0,9 \%$, we włocławskiej o $0,8 \%$. W większości diecezji wystąpił w tym okresie spadek liczby sióstr, lecz największy był on w diecezji pelplińskiej - o 33,3\% oraz w poznańskiej - o 29,3\%, kieleckiej - o 23,8\%, opolskiej - o 23,5\%, warszawskiej - o 16,3\%, gdańskiej o $26,3 \%$ i gliwickiej - o 25,0\%.

$\mathrm{Z}$ kolei największa liczba braci zakonnych pracowała w następujących diecezjach: w poznańskiej ( 235 w 2005 r. i 82 w 2017 r.); w warszawskiej (211 i 146); w krakowskiej (172 i 90); we włocławskiej (71 i 37). W pozostałych diecezjach liczby braci zakonnych były już mniejsze - od 1 (zamojsko-lubaczowska) do 60 (częstochowska). Siostry i bracia zakonni odgrywają bardzo ważną rolę w diecezjach, świadcząc różnego rodzaju prace i posługi religijne w urzędach kurialnych, w parafiach, w katechezie szkolnej, dlatego władze kościelne zabiegają o ich obecność na terytorium własnej diecezji. 


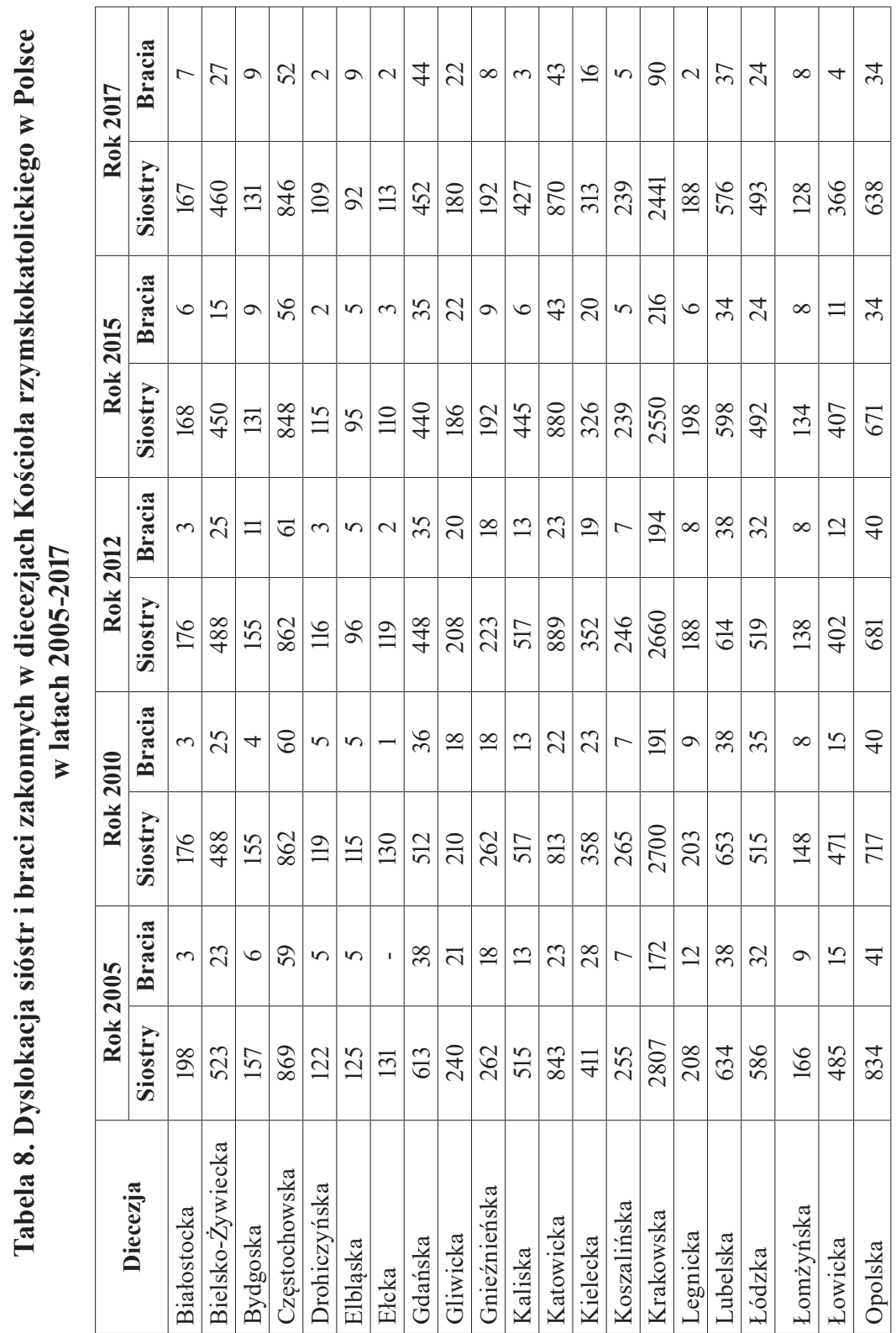




\begin{tabular}{|c|c|c|c|c|c|c|c|c|c|c|c|c|c|c|c|c|c|c|c|c|}
\hline 곡 & 音 & $\nabla$ & 으 & $\infty$ & in & $=$ & $\infty$ & 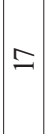 & $\vec{\sim}$ & 0 & in & $\because$ & $=\mathrm{r}$ & -0 & $\circ$ ○ & 으 & $\hat{n} \underset{\sim}{\infty}$ & - & $r$ & ชู \\
\hline$\approx$ & 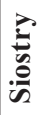 & $\infty$ & $\stackrel{\infty}{\stackrel{\nu}{\sim}}$ & ๙ু & $\hat{n}$ & m & $\stackrel{\substack{+m}}{m}$ & $\begin{array}{l}0 \\
m \\
m\end{array}$ & 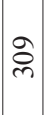 & I & $\hat{\underline{0}}$ & $\begin{array}{l}n \\
\text { of } \\
\text { t }\end{array}$ & $\stackrel{2}{2} \frac{9}{\delta}$ & $\stackrel{\infty}{\stackrel{\sim}{\sim}} \stackrel{J}{\sim}$ & 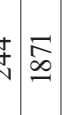 & $\begin{array}{l}0 \\
2 \\
n \\
2\end{array}$ & $\underset{\sim}{\approx} \underset{\infty}{\infty}$ & 足 & $\stackrel{\infty}{ }$ & 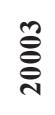 \\
\hline 号 & 音 & $\nabla$ & $\simeq$ & $\approx$ & $\stackrel{\infty}{m}$ & $=$ & $\infty$ & $\simeq$ & ㄱ. & 0 & $\nabla$ & 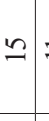 & $=\mathrm{r}$ & $\therefore \quad$ & 요 & 으 & $\approx \approx$ & $\sim$ & $\infty$ & $\frac{m}{a}$ \\
\hline 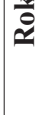 & 紊 & $\stackrel{\infty}{\Xi}$ & $\stackrel{\circ}{\sim}$ & ब & n & లె & 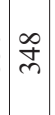 & $\begin{array}{l}\mathbb{Z} \\
\text { D }\end{array}$ & ○ & I & $\stackrel{f}{ \pm}$ & 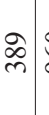 & $\begin{array}{lll}\circ & 5 \\
2 & \end{array}$ & $\stackrel{\vec{D}}{\sim} \stackrel{+}{\sim}$ & \begin{tabular}{l}
$f$ \\
\multirow{v}{*}{} \\
$\mathrm{v}$
\end{tabular} & $\left|\begin{array}{l}\tilde{0} \\
-1\end{array}\right|$ & $\underset{ల}{\infty} \underset{\infty}{\approx}$ & $\stackrel{0}{ \pm}$ & $\cong$ & $\underset{\sim}{\stackrel{f}{8}}$ \\
\hline ్ㅗㄱ & 童 & $\nabla$ & 寸 & $\frac{\beth}{\sim}$ & $\infty$ & \pm & 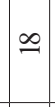 & $\simeq$ & 2 & $r$ & 0 & $\stackrel{ }{0}$ & 으 & ० & $\vec{v}$ & $\because$ & $\bar{r}$ & - & $a$ & ले \\
\hline 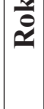 & 紊 & 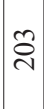 & $\stackrel{\overbrace{}}{\stackrel{\nu}{\nu}}$ & $\stackrel{n}{\circ}$ & $\hat{\circ}$ & $\stackrel{n}{n}$ & సి & 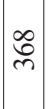 & 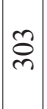 & $\widehat{\beth}$ & $\tilde{n}$ & $\stackrel{\overbrace{}}{ণ}$ & $\begin{array}{lll}\stackrel{1}{2} \\
\infty \\
\infty\end{array}$ & $\stackrel{n}{\stackrel{n}{v}} \stackrel{0}{+}$ & 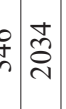 & $\left|\begin{array}{l}\tilde{0} \\
-1\end{array}\right|$ & 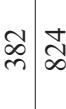 & 王 & $\bar{\Omega}$ & $\underset{\widetilde{\pi}}{\bar{\pi}}$ \\
\hline 을 & 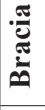 & $m$ & లె & $\tilde{\approx}$ & gे & సి & 으 & $=$ & 2 & 0 & $n$ & $\infty$ & $\cong r$ & 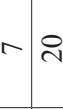 & $\vec{v} \mid$ & $\stackrel{\infty}{=}$ & $\approx \approx \infty$ & -1 & $a$ & ๙ิ \\
\hline $\begin{array}{l}\stackrel{\varkappa}{\hat{\theta}} \\
\simeq\end{array}$ & 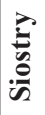 & ఫ্ণ & $\stackrel{\sim}{\sim}$ & $\stackrel{\text { I }}{\stackrel{I}{I}}$ & $\hat{\circ}$ & $\stackrel{m}{n}$ & $\frac{n}{2}$ & \begin{tabular}{|l|}
0 \\
o \\
t
\end{tabular} & ৪্ & $\ddot{m}$ & $\cong$ & $\underset{\mathcal{Y}}{\mathfrak{T}}$ & 守 & $\stackrel{\vec{\imath}}{\stackrel{\infty}{\curvearrowright}}$ & 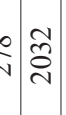 & $\mid \begin{array}{l}\hat{b} \\
\tilde{n}\end{array}$ & 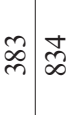 & $\bar{\Xi}$ & 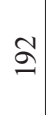 & $\frac{3}{2}$ \\
\hline 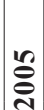 & 䇋 & $m$ & $m$ & $\tilde{n}$ & $\stackrel{\infty}{+}$ & సి & $\underline{6}$ & $\simeq$ & 9 & in & $\infty$ & $=$ & $\pm \alpha$ & $\infty \bar{v}$ & $\vec{v} \overrightarrow{\bar{v}}$ & ㄱ. & ₹ ले & $\sim$ & $a$ & $\stackrel{\substack{n \\
=}}{2}$ \\
\hline 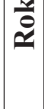 & 紊 & $\stackrel{\circ}{\stackrel{2}{*}}$ & $\stackrel{0}{\sim}$ & סे & $\stackrel{8}{\circ}$ & $\stackrel{\circ}{\gamma}$ & mे & $\frac{0}{\gamma}$ & $\vec{\sim}$ & I & $\bar{\infty}$ & 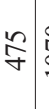 & 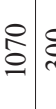 & 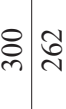 & 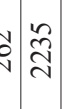 & $\stackrel{\mathrm{I}}{\exists}$ & ๙ેळ & 守 & 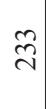 & बे \\
\hline . & 。ِّ & 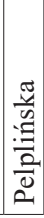 & $\frac{\pi}{0}$ & 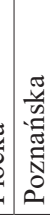 & 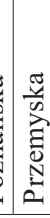 & $\left\{\begin{array}{l}\tilde{\sigma} \\
\tilde{\tilde{J}} \\
\tilde{0} \\
\tilde{\tilde{\sigma}} \\
\tilde{\sim}\end{array}\right.$ & 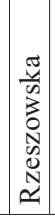 & 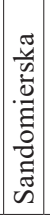 & 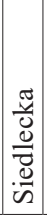 & 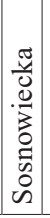 & \begin{tabular}{|c|}
$\frac{\pi}{\tilde{y}}$ \\
$: \vdots$ \\
$:$ \\
$\tilde{U}$ \\
$\tilde{N}$ \\
$\tilde{N}$ \\
$\sim$ \\
\end{tabular} & \begin{tabular}{c|c}
$\frac{\pi}{4}$ \\
$\frac{0}{0}$ \\
$\frac{0}{3}$ \\
0 \\
0
\end{tabular} & 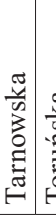 & 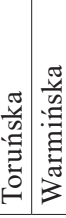 & 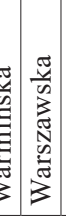 & 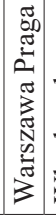 & 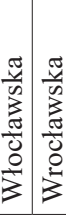 & 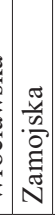 & 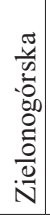 & 吾 \\
\hline
\end{tabular}


Biorąc pod uwagę brzegowe wskaźniki obu typów powołań zakonnych, można zauważyć, że w badanym okresie 2005-2017 wystąpił znaczny regres ich liczby: w środowisku sióstr zakonnych sięgnął on 13,8\% (mniej o 3196 sióstr w 2017 r.) i w środowisku braci zakonnych - 34,4\% (mniej o 473 braci w 2017 r.).

W 2016 r. w 2218 domach i wspólnotach klasztornych przebywało 18197 sióstr. Dyslokacja w 104 zgromadzeniach zakonnych była wtedy bardzo zróżnicowana, wskazując na zakres zainteresowania nimi wśród kobiet, które wstępowały właśnie do ich wspólnot. Zgromadzenia o dłuższej tradycji, odległej w czasie własnej historii, cieszą się większym zainteresowaniem kobiet niż zgromadzenia funkcjonujące w Polsce przez krótszy okres. O zainteresowaniu poszczególnymi zgromadzeniami żeńskimi decydują jeszcze inne czynniki, np. charyzmat i podstawowy cel oraz zasady służące funkcjonowaniu zakonu w Kościele i w społeczeństwie. Większym zainteresowaniem cieszą się zgromadzenia czynne w strukturach kościelnych i społecznych niż zakony kontemplacyjne odznaczające się odmiennym stylem i trybem codziennego życia zakonnic. ${ }^{16}$

Efektem popularności i zainteresowania są liczby sióstr żyjących w określonym zakonie, zajmując odpowiednią lokatę w ogólnej liczbie zgromadzeń, które funkcjonowały w Polsce w 2016 r. Największą liczbę sióstr, przekraczającą 800 osób, widzimy w dwóch zgromadzeniach: służebniczek starowiejskich (888) i elżbietanek (858). Ponad 700 sióstr żyło wówczas w dwóch zgromadzeniach: szarytek (762) i nazaretanek (705). W zgromadzeniu felicjanek i rodziny Maryi przebywało ponad 600 sióstr, a ponad 500 sióstr miały służki Najświętszej Marii Panny i służebniczki śląskie oraz seraficki. W zgromadzeniu albertynek, służebniczek dębickich i urszulanek SJK przebywało ponad 400 sióstr.

Z kolei ponad 300 sióstr żyło w pięciu zgromadzeniach: sercanek, karmelitanek od Dzieciątka Jezus, Matki Bożej miłosierdzia, józefinek. Łącznie w tych 17 zgromadzeniach przebywała największa liczba sióstr 9351, stanowiąc 51,4\% całej ich zbiorowości w tym roku. Następną, też liczną grupę tworzą zgromadzenia, w których żyło wtedy od 200 do 294 sióstr. Łącznie w tych zgromadzeniach było 2625 sióstr, czyli 14,4\% całej zbiorowości. Liczną grupę tworzą zgromadzenia, w których żyło w tym roku od 101 do 190 sióstr. Ogółem było w nich 4319 sióstr, czyli 23,7\%. Jeśli

${ }^{16}$ K. D ę b ow s k a, Życie konsekrowane - jego istota i aktualna sytuacja w Polsce. 
uwzględnimy zgromadzenia, w których w tym roku przebywało od 100 do ponad 800 zakonnic, otrzymamy łączny ich wskaźnik 16295 sióstr, dający aż 89,5\% całej zbiorowości.

W pozostałych zgromadzeniach przebywały znacznie mniejsze liczby sióstr: w jednej kategorii było od 20 do 94, czyli łącznie 1686, stanowiąc 9,3\% całości. Końcową część zgromadzeń tworzą te wspólnoty zakonne, w których przebywało od czterech do dziewiętnastu sióstr, czyli łącznie 135, stanowiąc $1,2 \%$ całej zbiorowości. Takie zgromadzenia, jak córki świętego Pawła, misjonarki królowej Afryki i świętego Józefa z Cluny miały zaledwie po cztery siostry; z kolei sześć sióstr miały karmelitanki misjonarki, a siedem klaretynki misjonarki i dziewięć sióstr służebnice najświętszego Serca Jezusa. Wszystkie siostry mieszkały w różnej liczbie własnych domów czy wspólnot zakonnych - od 1 (trzy zgromadzenia) do 168 (służebniczki starowiejskie) czy 127 (elżbietanki), 83 (służki Najświętszej Maryi Panny), 81 (szarytki), 80 (służebniczki śląskie), 76 (felicjanki).

Warto jeszcze zwrócić uwagę w tej analizie na liczebność sióstr zakonnych na świecie i w Europie, by móc odnieść je do ich liczebności w Polsce. Statystki kościelne wskazują na dość znaczący spadek liczby sióstr zakonnych na świecie i w Europie w latach 2001-2015. W Europie spadek ten wyniósł o niespełna 100 tys. ( o ponad 30\%). Analogiczna sytuacja miała miejsce w tym okresie w populacji braci zakonnych - w Europie wyniósł o 25\%. Niewielki wzrost liczby braci zaznaczył się w Azji (15\%). W 2015 r. największe liczby osób zakonnych odnotowano w takich krajach europejskich, jak Włochy: kobiety - 36495 i mężczyźni - 29832; Hiszpania (35278 i 10895); Francja (25834 i 6262); Niemcy (19278 i 4697); Polska (19200 i 12504); Irlandia (6346 i 2488); Belgia (6455 i 1850); Portugalia (5187 i 1436); Anglia (4248 i 1434); Austria (4119 i 1950); Szwajcaria (3523 i 1099); Holandia (3990 i 1840); Chorwacja (2912 i 1037); Czechy (1415 i 697); Węgry (1059 i 638); Rumunia (1000 i 348); Malta (860 i 382); natomiast najmniej było w Bułgarii (69 i 37); Grecji (68 i 52); Rosji (350 i 150); Szkocji (310 i 86) ${ }^{17}$.

Dyslokacja braci w poszczególnych zgromadzeniach i zakonach jest bardzo zróżnicowana, zarówno w całym okresie, jak i w kolejnych latach. Jedynie w kilku zgromadzeniach przebywało wówczas od 50 do 170 braci,

\footnotetext{
17 Źródło:http://www.zyciezakonne.pl/wiadomosci/ucesm-osoby-konsekrowane-w-europie-39843/; http:/www.iskk.pl/badania/swiat/53-ksia-i-zakonnicy/ (dostęp: 24 VII 2018).
} 
a mianowicie są to: franciszkanie OFM (170), kapucyni (137), franciszkanie Conv. (97), paulini (72), bonifratrzy (70), bracia Serca Jezusa (63), oblaci Maryi Niepokalanej (48), salwatorianie (46), pallotyni (40). W tych zgromadzeniach i zakonach łącznie przebywało $51,4 \%$ braci. W 11 zgromadzeniach było poniżej 10 braci, stanowiąc 4,7\% globalnej ich liczby. Największą liczbę braci mieli w każdym roku i w całym okresie franciszkanie łącznie ujęci - 29,5\%. Zmianie ulegała liczba braci w kolejnym roku badanego okresu powodując spadek liczby poczynając od $2010 \mathrm{r}$. W kilkunastu zgromadzeniach nie było w ogóle zgłoszeń nowych powołań brackich w kilku następujących po sobie latach. W całym ośmioletnim okresie we wszystkich zgromadzeniach i zakonach przebywało i wykonywało różne prace niezbędne do funkcjonowania swoich wspólnot 1380 braci. Jeśli liczbę braci z 2010 roku uznamy za podstawę zmiany tej liczby w kolejnych latach (jako 100\%), wówczas dostrzeżemy systematyczny regres tych powołań. Regres ten kształtował się następująco: w 2011 r. o 51,7\%, w 2012 r. o 42,6\%, w 2013 r. o $34,0 \%$, w 2014 r. o $40,2 \%$, w 2015 r. o $38,0 \%$, w 2016 r. o $30,6 \%$, w 2017 r. o 31,9\%. W liczbach regres ten między 2010 i 2017 r. jest bardzo duży i wynosi 254 braci mniej. W kolejnych latach zmniejszała się liczba braci niemal we wszystkich zgromadzeniach i zakonach, wskazując na niski prestiż tego statusu i formy życia zakonnego w środowisku młodych i starszych mężczyzn. Warto zaznaczyć, że pod względem wieku w 2010 i 2017 r. dominowali bracia liczący od 41 do 50 lat $(30,5 \%$ i 28,6\%) nad liczącymi od 51 do 60 lat (24,8\% i 27,7\%), nad liczącymi od 31 do 40 lat (17,4\% i 22,2\%), nad od 51 do $60 \%$ (30,5\% i 29,6\%), nad liczącymi powyżej 60 lat ( $12,5 \%$ i 15,3) oraz liczących do 30 lat $(6,8 \%$ i 5,2\%). Wprawdzie najliczniejszą grupą są bracia od 40 do 50 lat (47,9\% i 51,8\%), to z drugiej strony w całym okresie zmniejszał się odsetek młodych braci i w średnim wieku, liczący 35-40 lat. Obecny kryzys powołań duchownych w Polsce objął nie tylko alumnów diecezjalnych i zakonnych, lecz w szczególności kandydatów obojga płci do życia zakonnego. Z relacji władz kościelnych i zakonnych wynika, że kryzys ten będzie się nasilał niemal w każdym seminarium i zgromadzeniu zakonnym. ${ }^{18}$

$18 \mathrm{~J} . \mathrm{B}$ a n i a k, Powołania do kapłaństwa i do życia zakonnego w Polsce w latach 1900-2010. Studium socjologiczne; K. S z a f r a n i e c, Teologia życia zakonnego, Collectanea Theologica 1/1980, s. 146-158. 


\section{Dynamika realizacji powołań zakonnych sióstr i braci w latach 1900-2017}

W zakończeniu analizy losów powołań zakonnych kobiet i mężczyzn w Polsce w przyjętym okresie 1900-2017 zwróćmy jeszcze uwagę na stopniowalność realizacji ich powołania we wspólnotach zakonnych. Zagadnienie to ukażemy w oparciu o dostępne statystki kościelne za lata 2000-2017, ujmując ich wskaźniki w tabelach zbiorczych. Ważna jest też kwestia rezygnacji sióstr i braci z życia zakonnego i powrotu ich do życia świeckiego. Etapowość rozwoju i utrwalania własnego powołania zakonnego według zasad przyjętych w danym zakonie i zgromadzeniu zakonnym ukazuje, że niektóre osoby zrezygnowały z kontynuowania formacji zakonnej przerywając ją na określonym etapie, zaś inne podjęły decyzję o wystąpieniu z zakonu bez względu na typ złożonego wcześniej ślubu i czas pobytu we wspólnocie zakonnej. Systematyczny spadek liczby zakonnych powołań kobiecych i męskich, obejmujący coraz mniejszą liczbę zgłoszeń kandydatek i kandydatów do różnych zakonów i zgromadzeń zakonnych oraz powiększającą się liczbę sióstr i braci występujących z własnych wspólnot zakonnych, niepokoi władze kościelne i zakonne, gdyż zjawisko to zagraża dalszemu istnieniu i funkcjonowaniu tych wspólnot w Polsce.

Analizując wskaźniki realizacji powołania zakonnego sióstr w latach 2000-2016 zamieszczone w tabeli 9, można sformułować następujące wnioski: 1) na wszystkich etapach procesu realizacji powołania zakonnego daje się zauważyć stopniowy regres liczby zakonnic; 2) systematycznie zmniejsza się liczba sióstr, które składają pierwsze śluby zakonne, a regres ten zwiększa się istotnie w populacji sióstr decydujących się na złożenie ślubów wieczystych; 3) znaczny odsetek sióstr umierał w tym okresie, mimo, iż wskaźnik ich umieralności malał z roku na rok, odgrywając ważną rolę w utrzymaniu globalnej liczby zakonnic, w zestawieniu z malejącym permanentnie spadkiem liczby nowo rekrutowanych kobiet do zakonów i zgromadzeń zakonnych.

W nowicjacie własną formację zakonną podjęło łącznie w tym okresie 4778 postulantek, a na tę globalną ich liczbę składają się liczby sióstr rozpoczynających formację w każdym kolejnym roku. Pierwsze śluby zakonne złożyło 4630 nowicjuszek, czyli mniej o 3,1\%, natomiast 148 nie podjęło tej decyzji. Pewną wątpliwość może wzbudzać większa liczba sióstr, które złożyły wieczyste śluby zakonne, gdyż liczba ich jest większa o 12 od liczby nowicjuszek składających pierwsze śluby czasowe. Być może śluby 
wieczyste złożyły wówczas siostry, które decyzję złożenia tych ślubów wcześniej odkładały w czasie. Sytuację taką widzimy kilkakrotnie w całym okresie: w roku 2006 (o 61 osób); w 2007 (o 66); w 2009 (o 87); w 2010 (o 58); w 2011 (o 50); w 2012 (o 41); w 2013 (o 51); w 2014 (o 35); w 2015 (o 31). W pozostałych latach dominowały, które już złożyły pierwsze śluby zakonne nad siostrami, które zastanawiały się złożeniem tych ślubów.

Liczba postulantek rozpoczynających własną formację zakonną malała systematycznie w kolejnych latach tworzących badany okres: od 5,7\% w 2002 r. do 43,4 w 2005 r. W latach 2007-2009 wskaźnik regresu rozpoczynających nowicjat postulantem przekroczył połowę rozpoczynających go w 2000 r. Liczba kandydatek rozpoczynających nowicjat zmniejszyła się radykalnie w latach 2011-2017, przekraczając 70\% liczby wyjściowej z 2000 r. Jeśli w 2000 r. nowicjat rozpoczęło 541 postulantek, to w 2017 r. uczyniło to zaledwie 121, w 2013 r. - 145, w 2011 r. - 157 i w 2014 r. - 174. Regres ten został wywołany systematycznie malejącą liczbą młodych kobiet wstępujących do zakonów i słabnącym zainteresowaniem życiem zakonnym w środowisku młodzieży żeńskiej w tamtym okresie.

Pierwsze własne śluby zakonne złożyło w 2000 r. 88,9\% nowicjuszek, a pozostałe $11,1 \%$ nie podjęło tej decyzji. W całym badanym okresie był to największy odsetek sióstr nowicjuszek, które w ten sposób ściślej związały się osobiście ze wspólnotą zakonną i w znaczącym stopniu zweryfikowały swoje powołanie zakonne. Spoglądając na wskaźniki zamieszczone w tabeli 9, można dostrzec, że w kolejnych latach tego okresu liczby nowicjuszek składających pierwsze śluby zakonne były już mniejsze i kształtowały się nieregularnie, nigdy nie przekroczyły wskaźnika ślubów z 2000 r. Najmniejsze odsetki nowicjuszek składały śluby w drugiej dekadzie badanego okresu, czyli w 2015 r. - 119 osób, w 2014 r. - 128 osób, w 2013 r. - 134 osoby, co w zestawieniu z wskaźnikiem składających śluby w 2000 r. (481 osób) oznacza, że w tamtych latach do pierwszych ślubów przystąpiło o ponad 70\% mniej nowicjuszek, a w latach 2011-2012 mniej o ponad $60 \%$ w zestawieniu ze wskaźnikiem ślubów z 2000 r. Natomiast w latach 2001-2005 spadek liczby nowicjuszek składających pierwsze śluby zakonne był najmniejszy i lokował się w granicach od 3,9\% (w 2002 r.) do $27,9 \%$ (w 2005 r.).

Ścisły związek z pierwszymi ślubami zakonnymi sióstr mają śluby wieczyste, które wiążą zakonnicę w trwały i zobowiązujący sposób ze wspólnotą zakonną i oznaczają, że traktuje ona swoje powołanie zakonne jako jedynie słuszną i trafną drogę własnego życia w połączeniu z wyłączną 


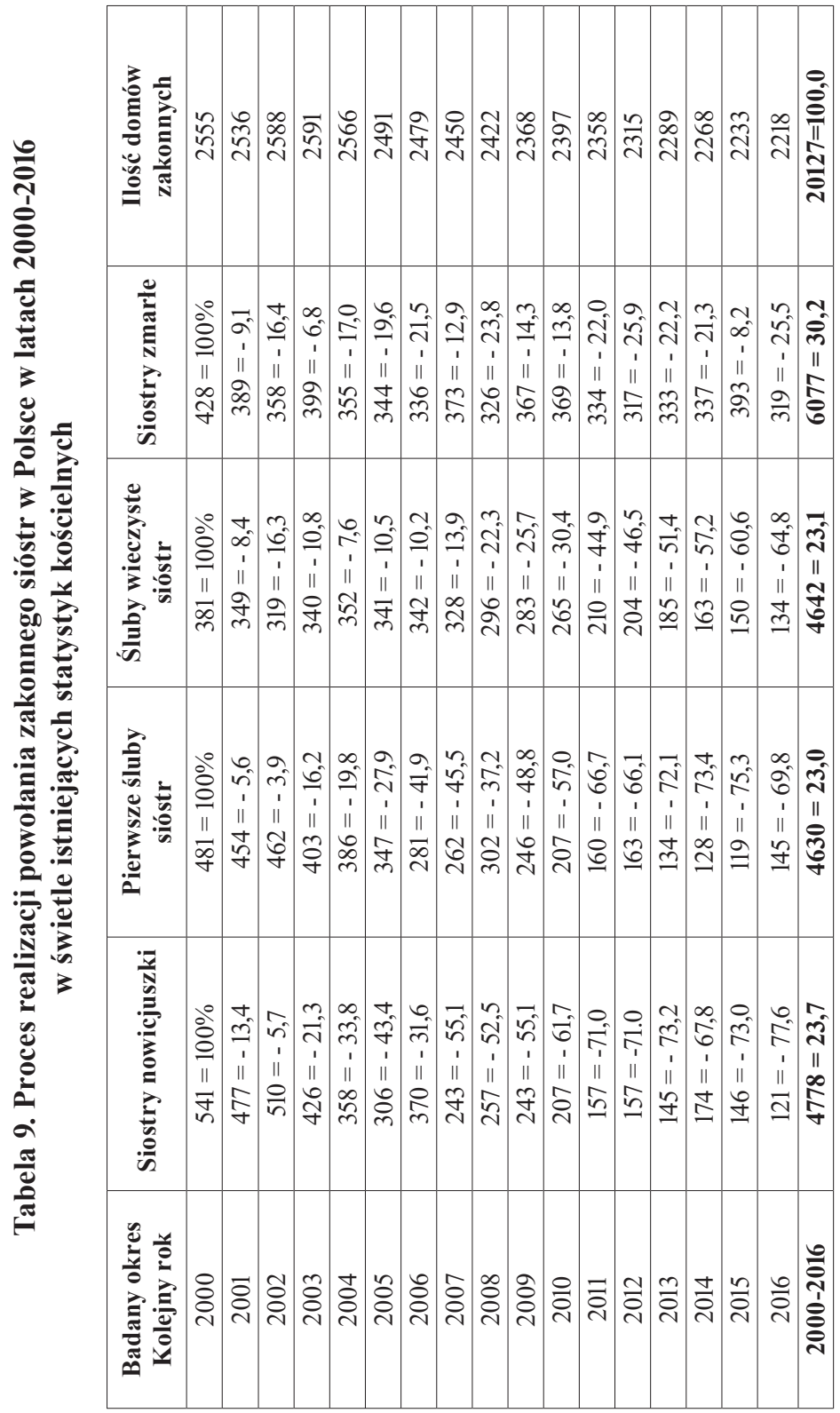


służbą Bogu i ludziom w Kościele. Tę odpowiedzialną decyzję podejmują już o wiele mniejsze odsetki sióstr nowicjuszek oraz tych, które są związane z zakonami przez dłuższy okres, lecz jeszcze nie podjęły decyzji o ślubach wieczystych z różnych powodów. W 2000 r. śluby wieczyste złożyło 381 sióstr, czyli mniej o $100 \mathrm{w}$ zestawieniu z liczbą pierwszych ślubów czasowych, które wtedy złożyło 481 sióstr nowicjuszek., a więc o 20,8\% mniej. W następnych latach tego okresu wskaźniki ślubów wieczystych systematycznie malały: od 8,4\% w 2001 r. do $13,9 \%$ w 2007 r. W latach 2008-2010 regres ich sięgał od 22,3\% do 30,4\%; w latach 2011-2012 był on jeszcze większy i przekroczył 40\%, a w latach 2013 - 2014 przekroczył $50 \%$ wskaźnika z 2000 r. Regres wskaźnika tych ślubów był największy w latach kończących badany okres i przekroczył 60\%, gdyż w 2016 r. wyniósł on aż $64,8 \%$.

Decyzja złożenia ślubów wieczystych na całe własne życie oznacza bardzo trudne zobowiązanie nawet dla sióstr, które nie mają zastrzeżeń lub wątpliwości co do swojego powołania zakonnego. Nie jest bowiem łatwo przewidzieć w tym momencie czy wytrwanie w tym zobowiązaniu nie zostanie poddane wątpieniu pod wpływem czynników zewnętrznych i osobistych samej zakonnicy. Tę sytuację klarowniej ukazują wskaźniki stanu liczbowego żeńskich zgromadzeń zakonnych w Polsce w latach 2000-2017 zaprezentowane w Internecie przez władze wspólnot zakonnych. Tabela 10 prezentuje stan kadrowy zgromadzeń zakonnych za ten okres.

$* * *$

Średnio w tym okresie w zgromadzeniach zakonnych w Polsce przebywały i realizowały własne powołanie zakonne 20703 siostry, chociaż w każdym kolejnym roku składającym się na ten okres 18 lat liczby sióstr były różne. W liczbie ogólnej wyraźnie dominują siostry, które już złożyły śluby wieczyste $(89,2 \%)$, nad siostrami po ślubach czasowych $(6,9 \%)$ oraz nad nowicjuszkami (2,3\%) i postulantkami (1,6\%). Obliczenia statystyczne ukazują trend spadkowy w każdej kategorii sióstr, aczkolwiek jest on najmniejszy wśród sióstr profesek wieczystych, sięgający od 0,1\% (w 2001 r.) do 14,1 (w 2017 r.). W pozostałych latach regres ten był nierównomierny, chociaż systematycznie wzrastał o kilka punktów procentowych. Regres ten był wielokrotnie większy w środowisku profesek czasowych i bardzo zróżnicowany w kolejnych latach: najmniejszy był w 2002 r. (0,2\%), a największy w 2017 r. (70\%), zaś w latach 2014-2016 przekroczył 60\% w zestawieniu 
z ich odsetkiem z 2000 r. (2167 wobec 809, 734, 697). Liczba sióstr składających śluby czasowe malała w stopniu o wiele większym niż liczba sióstr po ślubach wieczystych. Duży regres naboru do życia zakonnego wystąpił w tym okresie w grupie postulantek i nowicjuszek, zwłaszcza w drugiej połowie tego okresu - wśród postulantek przekroczył $60 \%$, a wśród nowicjuszek $70 \%$ w zestawieniu z odsetkiem ich z 2000 r. Spoglądając na cały badany okres 18 lat pod tym kątem, można zauważyć, że z roku na rok zmniejszała się liczba zgłoszeń kobiet do zakonów z decyzją o rozpoczęciu formacji swojego powołania, sprawdzenia jego autentyczności. Jeśli w 2000 r. w postulatach było 566 kobiet a nowicjatach 924 kobiety, to w $2017 \mathrm{r}$. ich liczby były znacznie mniejsze - 177 (mniej o 68,7\%) i 211 (mniej o 71,2\%). Różnica ta jest bardzo duża, a wielkość jej dokumentują w szczególności wskaźniki regresu z lat kończących badany okres.

Słabnące od wielu lat w Polsce w środowisku dziewcząt i młodych kobiet zainteresowanie kwestiami religijnymi i kościelnymi, w tym także życiem zakonnym, przekłada się na trwały spadek liczby ich zgłoszeń do zakonów i zgromadzeń zakonnych, rozpoczynania w nich osobistej formacji zakonnej. Zjawisko to jest dobrze znane władzom zakonnym, a jednocześnie inspiruje je do szukania zarówno przyczyn tego regresu powołań w środowiskach świeckich, z których wywodzą się te powołania, jak i we własnym środowisku zakonnym i kościelnym. Brak czy znikome liczby nowych powołań zakonnych zagrażają perspektywicznemu funkcjonowaniu zakonów żeńskich w Polsce, osłabiając jednocześnie wiele sfer aktywności religijnej i świeckiej w strukturach kościelnych. Nie jest łatwo rozwiązać ten problem, o czym dobrze wiedzą władze zakonne. Równie istotnym problemem dla kierownictwa zakonów żeńskich, obok braku licznych powołań do życia zakonnego, jest nasilające się od wielu lat występowanie sióstr z zakonów na różnym etapie swojej formacji i czasu życia we wspólnocie zakonnej i wracanie ich do życia świeckiego.

\section{Odejścia sióstr z zakonów i zgromadzeń zakonnych w Polsce w latach 2000-2016}

Z rozmów z licznymi zakonnicami, które opuściły zakony i zgromadzenia zakonne, a także z wyjaśnień tej kwestii przez władze zakonne w mediach publicznych wynika, że rezygnacje te są problemem skomplikowanym i kłopotliwym dla zakonów skłaniającym je do stawiania pytań o powody, przyczyny i motywy tych wystąpień - dlaczego tak się dzieje, a końca tego 


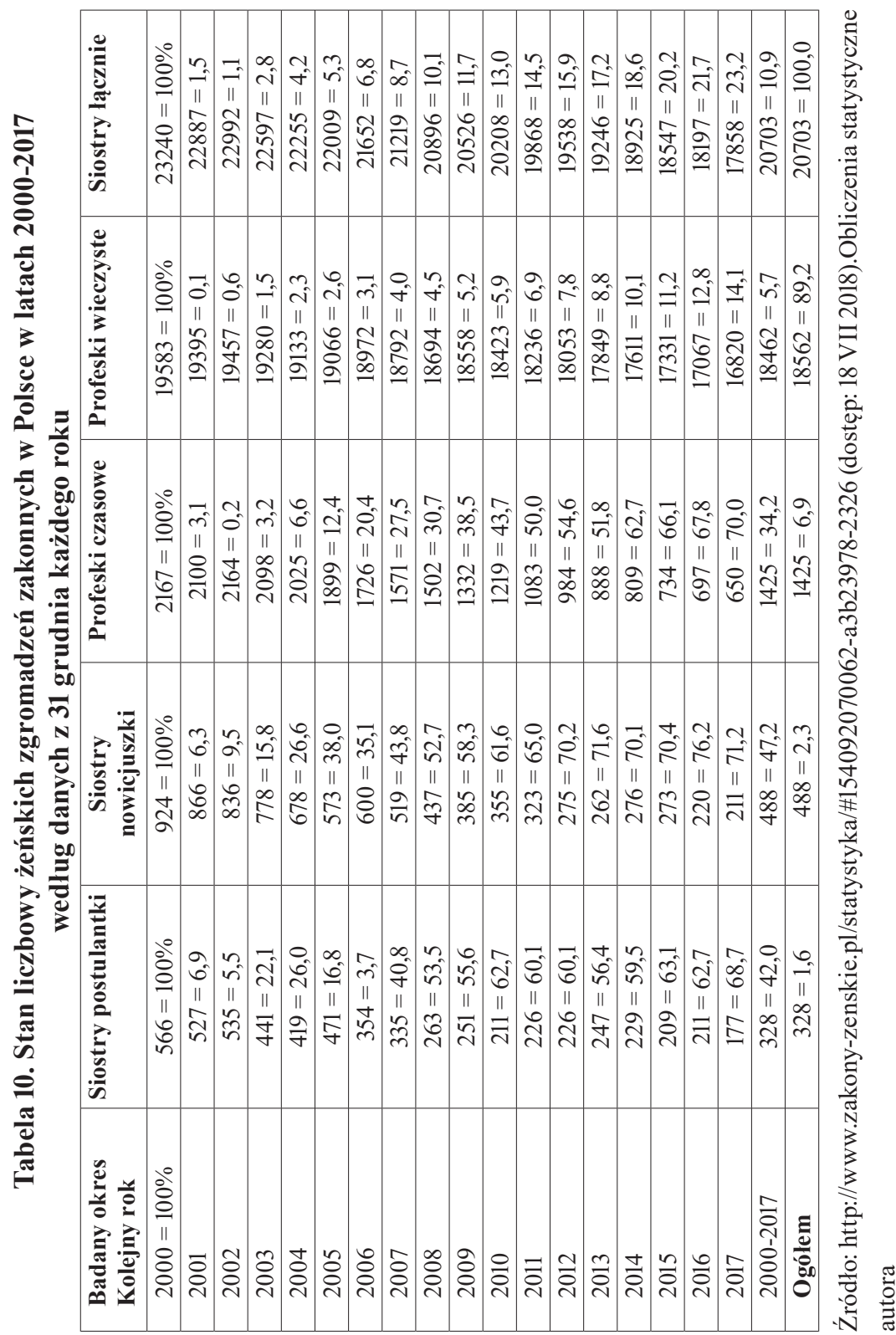


zjawiska nie widać na horyzoncie. Kwestię tę zasygnalizowałem częściowo w poprzednim akapicie, zwracając uwagę na jej wagę w funkcjonowaniu każdej wspólnoty zakonnej. W tabeli 11 ukazuję wskaźniki odejść sióstr ze zgromadzeń zakonnych opublikowane w Internecie przez władze zakonne, które ukazują to zjawisko za latach 2000-2016. Z zakonów odchodzą siostry na każdym etapie własnej formacji, adaptacji i życia w specyficznym i niełatwym życiu zakonnym i wspólnotowym.

W przyjętym okresie 16 lat ze zgromadzeń zakonnych odeszło łącznie 3175 sióstr, w tym 1282 postulantki (40,4\%0, 1029 po ślubach wieczystych $(32,4 \%)$ i 864 nowicjuszek (27,2\%). Najbardziej problematyczne są odejścia sióstr, które już złożyły wieczyste śluby zakonne i trwały w powołaniu przez dłuższy czas, nierzadko kilkanaście czy kilkadziesiąt lat, jak wnika z relacji ich przełożonych zakonnych. Siostry po ślubach wieczystych, a także dopiero będące w postulacie i nowicjacie, doszły do przekonania, że nie potrafią lub nie mogą dłużej być zakonnicami i zdecydowały się na opuszczenie wspólnot zakonnych. Z zakonów odchodzą siostry będące członkiniami zakonów kontemplacyjnych i zgromadzeń czynnych w strukturach kościelnych i świeckich, noszące stroje zakonne i bezhabitowe, młode, w średnim wieku i starsze, które były w zakonie kilkanaście lub kilkadziesiąt lat.

Odejścia sióstr na każdym etapie formacji zakonnej miały w kolejnych latach badanego okresu własną dynamikę i specyfikę. Systematycznie wspólnoty zakonne opuszczały siostry będące po ślubach wieczystych, jednak w 2002 r. odsetek odchodzących był mniejszy o 19,1\% w zestawieniu z ich liczbą w $2000 \mathrm{r}$. Natomiast w pozostałych 16 latach liczby sióstr po ślubach wieczystych były większe, niekiedy kilkakrotnie, od odsetka z 2000 r. Najwięcej spośród nich opuściło zgromadzenia zakonne w 2008 r. (70,2\%), w 2007 r. (59,6\%), w 20014 r. (53,2\%), w 2006 r. (44,7\%). W pozostałych latach odsetki tych sióstr odchodzących ze zgromadzeń i zakonów były mniejsze, wahając się od 12,8\% (najmniejszy) do 34,0\% (największy).

W grupie postulantek z zakonów odeszło łącznie $40,4 \%$, przy czym odsetki ich kształtowały się niejednolicie w kolejnych latach tego okresu. W 2000 r., rozpoczynającym ten okres, własne wspólnoty zakonne opuściło 84 siostry, a w kolejnych siedmiu latach liczby odchodzących były już większe - od 93 (w 2001 r.) do 113 (w 2006 r.). Natomiast do 2008 r. odejścia zmniejszyły się ilościowo, chociaż liczby tych sióstr były różne - większe (np. 75 w 2011 r.) i mniejsze (np. 39 w 2015 r.). Z nowicjatów odeszło najmniej sióstr - w całym okresie $27,2 \%$, chociaż w kolejnych latach liczby 


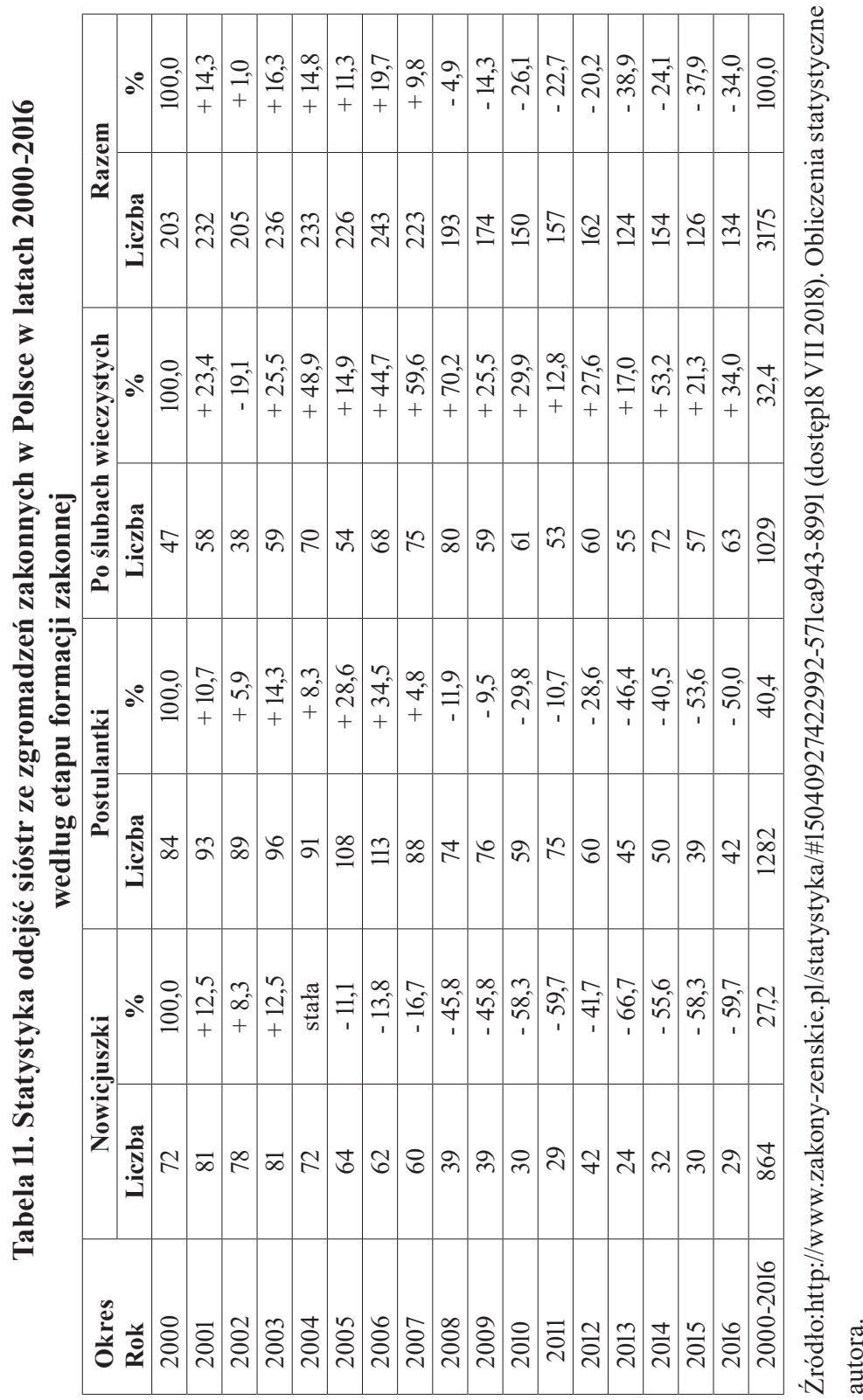


występujących były kilkakrotnie większe od liczby z 2000 r. (72) o kilka lub kilkanaście procent. Natomiast od 2005 r. liczby sióstr opuszczających zgromadzenia zakonne stopniowo zmniejszały się o kilkanaście procent, np. o 11,1\% w 2005 r. (najmniej) czy też o 59,7\% w 2011 r. i o 66,7\% w 2013 r., kiedy odeszły z zakonu 24 siostry albo 29 nowicjuszek w 2011 r. Jeśli 2017 r. w żeńskich zakonach w Polsce było łącznie 20.703 sióstr, to odsetek 3.175 odchodzących stanowi 15,3\% tej całości. Oznacza to, że co piąta siostra opuszczała w tym okresie zgromadzenie i wracała do życia świeckiego, instalując się w nim od nowa, nierzadko z dużymi trudnościami. ${ }^{19}$

$* * *$

W artykule zaprezentowałem socjologiczną analizę nie-kapłańskich powołań zakonnych sióstr i braci w Polsce, które zostały wzbudzone, uformowane i zrealizowane $\mathrm{w}$ okresie minionych 117 lat, ujętym $\mathrm{w}$ tej analizie w kilku podokresach, czyli w latach 1900-2017. Powołania wzbudzone i realizowane, to kandydatki i kandydaci aspirujący do specyficznej formy życia we wspólnocie zakonnej - czynnej w działalności religijnej i dobroczynnej Kościoła lub kontemplacyjnej, objętej ścisła klauzurą - formowani religijnie, moralnie i duchowo, przygotowywani do roli siostry zakonnej i do roli brata zakonnego w określonym zakonie czy zgromadzeniu zakonnym. Formacja zakonna i realizacja ich powołania odbywa się w postulatach i nowicjatach zakonnych. Z kolei powołania zrealizowane, to siostry i bracia zakonni, którzy już ukończyli okres próbny przygotowujący ich do życia we wspólnocie zakonnej, uzyskali niezbędną formację religijno-moralną, a następnie złożyli osobiste śluby zakonne czasowe i zdecydowali, że rozpoczną trwałe życie we własnych wspólnotach zakonnych według obowiązujących w nich reguł. Po upływie wskazanego okresu siostry i bracia składają uroczyste śluby wieczyste, oznajmiając $w$ ten sposób, że własne życie wiążą już na stałe z tym zakonem i rezygnują z powrotu do życia świeckiego. Podstawę ich życia codziennego są zasady ewangeliczne: posłuszeństwa, celibatu i ubóstwa oraz specyficzne reguły obyczajowe związane $\mathrm{z}$ charyzmatem ich zakonu lub zgromadzenia. Siostry i bracia po ślubach wieczystych stanowią grupę zakonników najbardziej stabilną we własnych wspólnotach.

Wyniki badań socjologicznych zaprezentowane w tym studium wskazują, że w Polsce w minionym okresie 117 lat liczebność obu typów powołań

19 M. A b r a mow i c z, Zakonnice odchodza po cichu. 
zakonnych była bardzo zróżnicowana, prowadząc niekiedy do ich kryzysu ilościowego. Liczba ta w niektórych podokresach zmniejszała się radykalnie w dwóch aspektach: z jednej strony, do zakonów i zgromadzeń zgłaszały się coraz mniejsze liczby kobiet i mężczyzn zamierzających rozpocząć własne życie zakonne, a z drugiej strony, systematycznie wzrastały odsetki sióstr-nowicjuszek, które z różnych przyczyn rezygnowały z własnej formacji zakonnej przed ślubami czasowymi, jak i sióstr już po ślubach wieczystych, i powracały do życia świeckiego. Sytuacja ta była jeszcze bardziej skomplikowana w populacji braci zakonnych, ponieważ rola brata zakonnego jako pomocnicza w życiu męskiej wspólnoty zakonnej, rzadziej interesowała mężczyzn, niż rola siostry interesowała kobiety i dziewczęta. W rezultacie na podjęcie się tej roli decydowali się nieliczni mężczyźni, spośród których tylko niektórzy kończyli owocnie swoją formację zakonną, składali czasowe i wieczyste śluby zakonne i pozostawali na stałe w swoich wspólnotach zakonnych.

Obecnie w wielu zakonach żeńskich liczba kandydatek na zakonnice, jak i liczba zakonnic już uformowanych, jest coraz mniejsza i ciągle zmniejsza się pod wpływem różnych czynników. Podobnie sytuacja ta kształtuje się w populacji kandydatów do roli brata zakonnego, jak i w liczebności braci zakonnych. Sytuacja kryzysowa powołań zakonnych zmusza władze zakonów i zgromadzeń zakonnych do stosowania nowoczesnych form i metod zachęcania i naboru nowych kandydatek i kandydatów do życia zakonnego we własnych wspólnotach, bazujących na wiedzy psychologicznej, pedagogicznej i socjologicznej, jak i z zakresu reklamy i marketingu. Informacje o życiu zakonnym i różnych wspólnotach zakonnych męskich i żeńskich ludzie młodzi i osoby dorosłe mogą uzyskać też w Internecie, a także w prasie religijnej i kościelnej. Oczywiście, te metody nie zastąpią bezpośredniego kontaktu przedstawicieli zakonów z młodzieżą w procesie zapoznawania i naboru kandydatów do życia zakonnego, jak tzw. próbnych spotkań kandydatów z siostrami i braćmi w zakonach.

Losy tych powołań, to proces rozpoczynający się od pierwszej myśli o życiu zakonnym pojawiającej się w świadomości młodej jednostki - kobiety i mężczyzny, następnie biegnący przez ich osobiste decyzje o wyborze życia zakonnego; przez wstąpienie kobiety i mężczyzny do zgromadzenia zakonnego i rozpoczęcie w nim formacji przygotowującej do życia zakonnego; przez okres wieloletniej formacji zakonnej; wreszcie ukończenie tych formacji i złożenie ślubów zakonnych i zostanie członkinią lub członkiem danej wspólnoty zakonnej. Każde powołanie do stanu duchownego ma 
własny los, gdyż oznacza ono zawsze odrębnego człowieka, który podjął myśl, a później decyzję o oddaniu własnego życia na służbę innym ludziom w Kościele i na służbę Bogu na warunkach wyłączności. Służba ta to służba zakonnicy i brata zakonnego.

Losy powołań zakonnych nie zawsze przebiegają prostolinijnie i bezproblemowo, prowadząc wybranego człowieka do trwałego życia zakonnego. Niekiedy losy te są skomplikowane, zwłaszcza wtedy, kiedy młody człowiek, mężczyzna i kobieta, podejmują decyzję o wyborze życia zakonnego, nie mając pełnego przekonania o tym wybraniu służby w stanie zakonnym. Konsekwencje takiej decyzji później komplikują osobiste życie tym mężczyznom i kobietom, ponieważ rezygnują oni z życia zakonnego. Powrót ich do życia świeckiego, w małżeństwie i rodzinie, nie jest dla nich prosty i łatwy w praktyce. Im dłuższy okres żyli w celibacie i w warunkach wspólnoty zakonnej, tym trudniejsza okazuje się ich adaptacja do warunków życia świeckiego. Badania wykazały, że duży odsetek sióstr rezygnujących z życia zakonnego, ma trudności w dostosowaniu się do warunków życia świeckiego w małżeństwie i rodzinie, gdyż warunki te nie były im znane jako osobom zakonnym żyjącym w celibacie i samotności przez wiele lat. Tym skomplikowanym losom powołań zakonnych sióstr i braci w Polsce poświęciłem to studium socjograficzne, lokując je w warunkach długiego 117-letniego okresu. 